\title{
The European mountain cryosphere: a review of its current state, trends, and future challenges
}

Martin Beniston ${ }^{1,2}$, Daniel Farinotti ${ }^{3,4}$, Markus Stoffel ${ }^{1,5,6}$, Liss M. Andreassen $^{7}$, Erika Coppola ${ }^{8}$, Nicolas Eckert $^{9}$, Adriano Fantini $^{8}$, Florie Giacona ${ }^{1,9}$, Christian Hauck ${ }^{10}$, Matthias Huss ${ }^{10}$, Hendrik Huwald ${ }^{11}$, Michael Lehning ${ }^{11,12}$, Juan-Ignacio López-Moreno ${ }^{13}$, Jan Magnusson ${ }^{7}$, Christoph Marty ${ }^{12}$, Enrique Morán-Tejéda ${ }^{14}$, Samuel Morin ${ }^{15}$, Mohamed Naaim $^{9}$, Antonello Provenzale ${ }^{16}$, Antoine Rabatel ${ }^{17}$, Delphine Six $^{17}$, Johann Stötter ${ }^{18}$, Ulrich Strasser ${ }^{18}$, Silvia Terzago ${ }^{19}$, and Christian Vincent ${ }^{17}$

${ }^{1}$ Institute for Environmental Sciences, University of Geneva, Switzerland

${ }^{2}$ Department of Physics, University of Geneva, Switzerland

${ }^{3}$ Laboratory of Hydraulics, Hydrology and Glaciology (VAW), ETH Zurich, Zurich, Switzerland

${ }^{4}$ Swiss Federal Institute for Forest, Snow and Landscape Research (WSL), Birmensdorf, Switzerland

${ }^{5}$ Department of Earth Sciences, University of Geneva, Switzerland

${ }^{6}$ Department F-A Forel for Aquatic and Environmental Sciences, University of Geneva, Switzerland

${ }^{7}$ Norwegian Water Resources and Energy Directorate, Oslo, Norway

${ }^{8}$ Abdus Salaam International Centre for Theoretical Physics, Trieste, Italy

${ }^{9}$ Institut National de Recherche sur les Technologies pour l'Environnement et l'Agriculture (IRSTEA),

Saint Martin d'Hères, France

${ }^{10}$ University of Fribourg, Department of Geosciences, Fribourg, Switzerland

${ }^{11}$ École Polytechnique Fédérale de Lausanne, Laboratory for Cryospheric Sciences, Lausanne, Switzerland

${ }^{12}$ Swiss Federal Institute for Avalanche Research (SLF), Davos, Switzerland

${ }^{13}$ Institute for Pyrenean Ecology (IPE-CSIC), Zaragoza, Spain

${ }^{14}$ University of the Balearic Islands, Palma de Mallorca, Spain

${ }^{15}$ Météo France, Centre d'Études de la Neige, Saint Martin d'Hères, France

${ }^{16} \mathrm{CNR}$, Institute of Geosciences and Earth Resources, Pisa, Italy

${ }^{17}$ Univertisé Grenoble-Alpes, CNRS, IRD, G-INP, IGE (UMR 5001), 38000 Grenoble, France

${ }^{18}$ University of Innsbruck, Institute of Geography, Innsbruck, Austria

${ }^{19} \mathrm{CNR}$, Institute of Atmospheric Sciences and Climate (ISAC-CNR), Turin, Italy

Correspondence: Martin Beniston (martin.beniston@unige.ch) and Markus Stoffel (markus.stoffel@unige.ch)

Received: 20 December 2016 - Discussion started: 9 January 2017

Revised: 16 January 2018 - Accepted: 18 January 2018 - Published: 1 March 2018

\begin{abstract}
The mountain cryosphere of mainland Europe is recognized to have important impacts on a range of environmental processes. In this paper, we provide an overview on the current knowledge on snow, glacier, and permafrost processes, as well as their past, current, and future evolution. We additionally provide an assessment of current cryosphere research in Europe and point to the different domains requiring further research. Emphasis is given to our understanding of climate-cryosphere interactions, cryosphere controls on physical and biological mountain systems, and re-
\end{abstract}

lated impacts. By the end of the century, Europe's mountain cryosphere will have changed to an extent that will impact the landscape, the hydrological regimes, the water resources, and the infrastructure. The impacts will not remain confined to the mountain area but also affect the downstream lowlands, entailing a wide range of socioeconomical consequences. European mountains will have a completely different visual appearance, in which low- and mid-range-altitude glaciers will have disappeared and even large valley glaciers will have experienced significant retreat and mass loss. Due to increased 
air temperatures and related shifts from solid to liquid precipitation, seasonal snow lines will be found at much higher altitudes, and the snow season will be much shorter than today. These changes in snow and ice melt will cause a shift in the timing of discharge maxima, as well as a transition of runoff regimes from glacial to nival and from nival to pluvial. This will entail significant impacts on the seasonality of high-altitude water availability, with consequences for water storage and management in reservoirs for drinking water, irrigation, and hydropower production. Whereas an upward shift of the tree line and expansion of vegetation can be expected into current periglacial areas, the disappearance of permafrost at lower altitudes and its warming at higher elevations will likely result in mass movements and process chains beyond historical experience. Future cryospheric research has the responsibility not only to foster awareness of these expected changes and to develop targeted strategies to precisely quantify their magnitude and rate of occurrence but also to help in the development of approaches to adapt to these changes and to mitigate their consequences. Major joint efforts are required in the domain of cryospheric monitoring, which will require coordination in terms of data availability and quality. In particular, we recognize the quantification of high-altitude precipitation as a key source of uncertainty in projections of future changes. Improvements in numerical modeling and a better understanding of process chains affecting high-altitude mass movements are the two further fields that - in our view - future cryospheric research should focus on.

\section{Introduction}

Ongoing climate change and the importance of its anthropogenic component have gained wide recognition (IPCC, 2013). Thereby, some regions are likely to be more vulnerable than others, in both the expected physical changes and the consequences for ways of life. Mountains are particularly subject to rapid and sustained environmental changes (Gobiet et al., 2014), and the cryosphere is the physical compartment that exhibits the most rapid ones. Changes in mountain snow, glaciers, and permafrost have resulted in significant downstream impacts in terms of the quantity, seasonality, and quality of water (Beniston et al., 2011a). This is particularly true for areas where snow and ice melt represent a large fraction of streamflow. Countless studies have reported glacier retreat, permafrost warming, and snowfall decrease across mountain regions in Europe, with implications for streamflow regimes, water availability, and natural hazards. These can in turn negatively impact hydropower generation, agriculture, forestry, tourism, and aquatic ecosystems. Consequently, downstream communities will also be under pressure, and mountain forelands with densely populated areas will be highly affected (Kaser et al., 2010; Huss et al., 2017).
Both political and scientific programs are calling for better preparedness and for the development of strategies aimed at averting possible conflicts of interest, such as between economic goals and environmental protection (Beniston et al., 2014).

In the following, we provide an overview of the current knowledge of European mountain permafrost, glaciers, and snow and the observed changes. We focus on mainland $\mathrm{Eu}-$ rope, in particular the European Alps and Scandinavia, but also include - where possible - the Pyrenees and other midlatitude European mountains. An assessment of the challenges that need to be addressed in cryosphere research is provided, and we identify areas where further progress is required to improve our understanding of climate-cryosphere interactions. We argue that such improved understanding is the key for better predicting future changes and impacts and for appropriate adaptation measures to be developed. Our views largely reflect the opinions of a body of scientists that convened during the "Riederalp Cryosphere Workshop" held in Switzerland in 2016. We therefore do not claim that all aspects of cryosphere sciences are exhaustively covered or that all possible elements of the cryosphere are discussed (we neglect, for example, lake ice, river ice, and ice in caves), but we have summarized, in an effective manner, both the current state and the future challenges in the domain of European mountain cryosphere research.

\section{Past and future trends in European mountain cryosphere and their impacts}

\subsection{Changes in snow}

Snow cover is the most important interface between the atmosphere and the ground, strongly influencing the surface energy balance of the cryosphere. Snow affects glaciers through albedo and mass balance and affects permafrost through its thermal insulation properties and meltwater input. It also plays a key role for sustaining ecological and socioeconomic systems in mountains as well as in the lowlands downstream of the mountain ranges. The extreme spatiotemporal variability of the snow cover remains one of the key uncertainties when quantifying the impact of climate change on the cryosphere. Snow observations are therefore a prerequisite for understanding the related processes and for providing more reliable assessments of future changes.

\subsubsection{Observed changes of the snow cover}

Most studies show negative trends in snow depth and snow duration over the past decades (Table 1). These negative trends are well documented in the Alps due to the abundance of long-term observations. The changes are typically elevation dependent, with more (less) pronounced changes at low (high) elevations (Marty, 2008; Durand et al., 2009; Terzago et al., 2013). Decrease in spring snow water equiv- 
Table 1. Recent studies of current snow cover trends in the major European mountain regions. Only significant trends are listed. Note that a direct comparison of the sites is difficult since the considered time period and snow variable can differ.

\begin{tabular}{|c|c|c|c|c|c|}
\hline & Time & Snow variable & \multicolumn{2}{|c|}{ Trend at low and high elevation } & Source \\
\hline $\begin{array}{l}\text { Alps } \\
\text { Switzerland } \\
\text { Italy } \\
\text { France }\end{array}$ & $\begin{array}{l}1958-1999 \\
1950-2009 \\
1959-2005\end{array}$ & $\begin{array}{l}\text { DJF snow cover duration } \\
\text { DJFMA snow cover duration } \\
\text { annual snow cover duration }\end{array}$ & $\begin{array}{l}\text { below } 2000 \mathrm{~m} \\
\text { majority negative } \\
\text { majority negative } \\
\text { majority negative }\end{array}$ & $\begin{array}{l}\text { above } 2000 \mathrm{~m} \\
\text { no clear trend } \\
\text { no clear trend } \\
\text { many negative }\end{array}$ & $\begin{array}{l}\text { Scherrer et al. (2004) } \\
\text { Valt and Cianfarra (2010) } \\
\text { Durand et al. (2009) }\end{array}$ \\
\hline $\begin{array}{l}\text { Scandinavia } \\
\text { Norway } \\
\text { Finland }\end{array}$ & $\begin{array}{l}1961-2010 \\
1978-2012\end{array}$ & $\begin{array}{l}\text { maximum snow depth } \\
\text { annual snow cover duration }\end{array}$ & $\begin{array}{l}\text { below } 1000 \mathrm{~m} \\
\text { majority negative } \\
\text { majority negative }\end{array}$ & $\begin{array}{l}\text { above } 1000 \mathrm{~m} \\
\text { some positive } \\
-\end{array}$ & $\begin{array}{l}\text { Dyrrdal et al. (2013) } \\
\text { Kivinen and Rasmus (2015) }\end{array}$ \\
\hline $\begin{array}{l}\text { Carpathians } \\
\text { Bulgaria } \\
\text { Poland } \\
\text { Romania }\end{array}$ & $\begin{array}{l}1931-2000 \\
1954-2001 \\
1961-2003\end{array}$ & $\begin{array}{l}\text { annual snow cover duration } \\
\text { maximum snow depth } \\
\text { annual snow cover duration }\end{array}$ & $\begin{array}{l}\text { below } 1000 \mathrm{~m} \\
\text { no clear trend } \\
\text { no clear trend } \\
\text { no clear trend }\end{array}$ & $\begin{array}{l}\text { above } 1000 \mathrm{~m} \\
\text { no clear trend } \\
\text { no clear trend } \\
\text { no clear trend }\end{array}$ & $\begin{array}{l}\text { Brown and Petkova (2007) } \\
\text { Falarz (2008) } \\
\text { Micu (2009) }\end{array}$ \\
\hline $\begin{array}{l}\text { Pyrenees } \\
\text { Spain }\end{array}$ & 1975-2002 & annual snow cover duration & $\begin{array}{l}\text { below } 1000 \mathrm{~m} \\
\text { majority negative }\end{array}$ & $\begin{array}{l}\text { above } 1000 \mathrm{~m} \\
\text { majority negative }\end{array}$ & Pons et al. (2010) \\
\hline
\end{tabular}

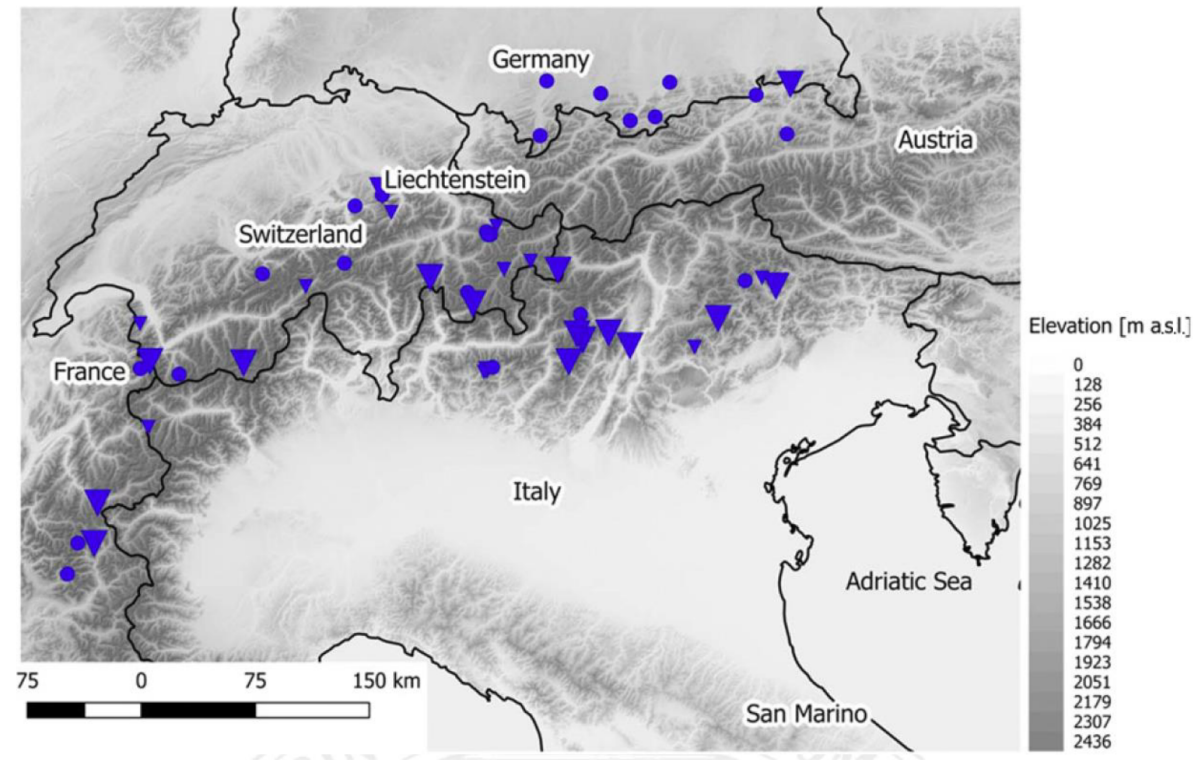

Figure 1. Geographical distribution of the 45-year trend (1968-2012) for 1 April snow water equivalent (SWE) in the Alps. All stations show a negative trend. Large triangles indicate significant trends $(p=0.05)$ and small triangles indicate weakly significant trends $(p=0.2)$. Circles represent stations with no significant trend $(p=0.2)$. The elevation is given in gray. (Adapted from Marty et al., 2017b.)

alent (SWE) is equally found for the Alps (Bocchiola and Diolaiuti, 2010; Marty et al., 2017b; Fig. 1) as well as for low elevations in Norway (Skaugen et al., 2012). Only the higher and colder regions of the Fennoscandian mountains exhibit positive trends of maximum snow depth and maximum SWE, although trends have recently become negative in these regions too (Johansson et al., 2011; Skaugen et al., 2012; Dyrrdal et al., 2013; Kivinen and Rasmus, 2015). In the Pyrenees, a significant reduction of the snowpack is reported since the 1950s (Pons et al., 2010), and in other European mountains - where observations are less abundant - studies also report declining snowpacks. The latter is particularly true for mountains in Romania (Birsan and Dumitrescu, 2014; Micu, 2009), Bulgaria (Brown and Petkova, 2007), Poland (Falarz, 2008), and Croatia (Gajić-Čapka, 2011).

The observed changes in snow depth and snow duration are mainly caused by a shift from solid to liquid precipitation (Serquet et al., 2011; Nikolova et al., 2013) and by more frequent and more intense melt (Klein et al., 2016), both resulting from higher air temperatures during winter and spring. In addition to a general warming trend, large-scale atmospheric circulation patterns such as the North Atlantic Oscillation 
(NAO) have been shown to influence the snow cover in Europe (Henderson and Leathers, 2010; Bednorz, 2011; Skaugen et al., 2012; Birsan and Dumitrescu, 2014; Buisan et al., 2015). For the Alps, $50 \%$ of the snowpack variability seems to be related to the establishment of atmospheric blocking patterns over Europe, although in this case the correlation between the annual snowpack variability and the NAO is weak and limited to low elevations (Scherrer and Appenzeller, 2006; Durand et al., 2009). At higher elevations, the NAO influence can be detected a through a "cascade" of processes that include the manner in which the positive or negative NAO modes translate into surface pressure in the Alps, Pyrenees, or Scandes and thus influence temperature and precipitation according to the resulting pressure patterns in the different European mountain regions. Together with the effect of air temperature, this determines the amount of snowfall. In recent decades, this cascade has led to an increased number of warm and dry winter days, which obviously is unfavorable for snow accumulation (Beniston et al., 2011b). In addition, the Atlantic Multidecadal Oscillation - a natural periodic fluctuation of North Atlantic sea surface temperature - has been shown to affect the variability of alpine spring snowfall, contributing to the decline in snow cover duration (Zampieri et al., 2013).

The observed changes in snow amounts are often abrupt. Several studies have reported a step-like change for snow depth occurring in the late 1980s (Marty, 2008; Durand et al., 2009; Valt and Cianfarra, 2010) and for snow-covered areas of the Northern Hemisphere (Choi et al., 2010). This steplike development, also observed for other compartments of the environment (Reid et al., 2016), has been suggested to be linked to atmospheric internal variability ( $\mathrm{Li}$ et al., 2015) and shrinking sea-ice extent (Mori et. al. 2014). Since that step change, the monthly mean snow-covered area in the Alps has not decreased significantly (Hüsler et al., 2014), and winter temperatures in large areas of the Northern Hemisphere (Mori et. al. 2014) and in the Swiss Alps (Scherrer et al., 2013) have been stagnating.

Studies analyzing high-magnitude snowfalls are rare, but they indicate that extreme snow depths have decreased in $\mathrm{Eu}-$ rope (Blanchet et al., 2009; Kunkel et al., 2016), with the exception of higher and colder sites in Norway (Dyrrdal et al., 2013). The decrease in extreme snowfall rates is less clear, except for low elevations where the influence of increasing air temperature is predominant (Marty and Blanchet, 2012). Studies related to past changes in snow avalanche activity are scarce as well, but observations indicate that over the last decades (a) the number of days with prerequisites for avalanches in forests decreased (Teich et al., 2012), (b) the proportion of wet snow avalanches increased (Pielmeier et al., 2013), and (c) the runout altitude of large avalanches retreated upslope (Eckert et al., 2010, 2013; Corona et al., 2013) as a direct consequence of changes in snow cover characteristics (Castebrunet et al., 2012).

\subsubsection{Future changes of the snow cover}

Regional climate model simulations show a dramatic decrease both in snow cover duration and SWE for Europe by the end of the 21 st century (Jylhä et al., 2008). It has to be noted, however, that the projected increase in air temperature for coming decades is accompanied by large uncertainties in changes of winter precipitation. For mainland Europe, climate models show no clear precipitation change until the 2050s and slightly increasing winter precipitation thereafter. Projections for regional changes in snow cover are thus highly variable and strongly depend on applied emission scenarios and considered time period (e.g., Marke et al., 2015).

For the Alps at an elevation of $1500 \mathrm{~m}$ a.s.l. (above sea level), recent simulations project a reduction in SWE of 80$90 \%$ by the end of the century (Rousselot et al., 2012; Steger et al., 2013; Schmucki et al., 2015a). According to the same simulations, the snow season at that altitude would start 2-4 weeks later and end 5-10 weeks earlier than in the 1992-2012 average, which is equivalent to a shift in elevation of about $700 \mathrm{~m}$ (Marty et al., 2017a). For elevations above 3000 ma.s.l., a decline in SWE of at least $10 \%$ is expected by the end of the century even when assuming the largest projected precipitation increase. Future climate will most probably not allow for the existence of a permanent snow cover during summer even at the highest elevations in the Alps, with obvious implications for the remaining glaciers (Magnusson et al., 2010; Bavay et al., 2013) and the thermal condition of the ground (e.g., Marmy et al., 2016; Draebing et al., 2017; Magnin et al., 2017).

Projections for Scandinavia show clear decreases for snow amount and duration. Exceptions are the highest mountains in Northern Scandinavia, where strongly increasing amounts in precipitation could compensate the temperature rise and result in marginal changes only (Räisänen and Eklund, 2012). Simulations for the Pyrenees indicate a decline of the snow cover similar to that found for the Alps (LópezMoreno et al., 2009). Again, the dependency on future emissions is significant: for a high emission scenario (RCP8.5), SWE decreases by $78 \%$ at the end of the 21 st century at $1500 \mathrm{~m}$ a.s.l. elevation are expected, whereas a lower emission scenario (RCP6.0) projects a decline of $44 \%$.

Extreme values of snow variables are often the result of a combination of processes (e.g., wind and topographic influence for drifting snow), making predictions of their frequency highly uncertain (IPCC, 2012, 2013). By the end of the 21 st century, models suggest a smaller reduction in daily maximum snowfalls than in mean snowfalls over many regions of the Northern Hemisphere (O'Gorman, 2014). An investigation for the Pyrenees (López-Moreno et al., 2011), however, finds a marked decrease in the frequency and intensity of heavy snowfall events below $1000 \mathrm{ma}$ a.s.l. and no change in heavier snowfalls for higher elevations. Changes in extreme snowfall and snow depth are also likely to depend on compensation mechanisms between higher temper- 
atures (Nicolet et al., 2016), more intense precipitation, and increased climate variability, rendering any prediction of future snow storm frequency, magnitude, and timing difficult. In addition, most available studies either deal with marginal distributions or postulate stationarity (Blanchet and Davison, 2010; Gaume et al., 2013), two approaches that are questionable in the context of a changing climate.

Changes in snow cover duration and snow depth, as well as other snow properties, will have an effect on various ecosystems: earlier snowmelt is associated with an anticipation of plant phenology (Pettorelli et al., 2007) which can potentially induce a mismatch between plant blooming and herbivore activity, similar to observations in Arctic regions (Post et al., 2009). In the case of alpine ibex, for example, snow has been found to have a dual effect: too much winter snow limits adult survival, whereas too little snow produces a mismatch between alpine grass blooming and herbivore needs (Mignatti et al., 2012). Abundance of alpine rock ptarmigan populations, in contrast, has been shown to depend on the onset of spring snowmelt and the timing of autumn snow cover (Imperio et al., 2013). The increasing number of hard (icy) snow layers due to higher temperatures, however, can have a significant effect on the life of plants and animals (Johansson et al., 2011).

In addition, human activities will be influenced by the anticipated changes. The reduction of the snow season duration, for example, will have severe consequences for winter tourism (Uhlmann et al., 2009; Steiger and Abegg, 2013; Schmucki et al., 2015b), water management (Laghari et al., 2012; Hill-Clarvis et al., 2014; Gaudard et al., 2014; Köplin et al., 2014), and ecology (Hu et al., 2010; Martz et al., 2016). Similarly, change in moisture content or density of snow will affect infrastructure stability under extreme loading (Sadovský and Sykora, 2013; Favier et al., 2014).

The effect of climate change on avalanche risk is largely unknown; although empirical relations between snow avalanche activity and climate exist (Mock and Birkeland, 2000), the knowledge is insufficient for sound long-term projections. With a few exceptions, existing studies on avalanche-climate interactions focus on recent decades and are very local in scope (Stoffel et al., 2006; Corona et al., 2012, 2013; Schläppy et al., 2014, 2016). Direct effects of climate change on avalanche frequency, timing, magnitude, and type mainly exist in form of changes in snow amounts, snowfall succession, density, and stratigraphy as a function of elevation. The trend towards wetter snow avalanches is expected to continue, although the overall avalanche activity will decrease, especially in spring and at low elevations (Martin et al., 2001; Castebrunet et al., 2014). In contrast, an increase in avalanche activity is expected at high elevations in winter due to more favorable conditions for wet snow avalanches earlier in the season (Castebrunet et al., 2014). Even if the expected rise of tree line elevation may reduce both avalanche frequency and magnitude, present knowledge on avalanche-forest interactions is incomplete (Bebi et al.,
2009). Due to the highly nonlinear nature of avalanche triggering response to snow and weather inputs (Schweizer et al., 2003) and to the complex relations between temperature, snow amounts, and avalanche dynamics (Bartelt et al., 2012; Naaim et al., 2013), it remains unclear whether warmer temperatures will indeed lead to fewer avalanches because of less snow. The most destructive avalanches, moreover, mostly involve very cold and dry snow resulting from large snowfall, but they may also result from wet snow events whose frequency has increased in the past (Sovilla et al., 2010; Castebrunet et al., 2014; Ancey and Bain, 2015). Finally, mass movements involving snow often occur at very local scales, making them difficult to relate to climate model outputs, even with downscaling methods (Rousselot et al., 2012; Kotlarski et al., 2014).

\subsection{Changes in glaciers}

Mountain glaciers are a key indicator of rapid and global climate change. They are important for water supply as they modulate the water cycle at different temporal and spatial scales, affecting irrigation, hydropower production, and tourism. Evaluating the retreat or complete disappearance of mountain glaciers in response to climate change is important to estimate impacts on water resources (e.g., Kaser et al., 2010; Pellicciotti et al., 2014) and to anticipate natural hazards related to glacier retreat, e.g., ice avalanches or the formation of new lakes (Frey et al., 2010; Gilbert et al., 2012; Faillettaz et al., 2015; Haeberli et al., 2016, 2017).

\subsubsection{Observed changes in glaciers}

Glaciers in mainland Europe cover an area of nearly $5000 \mathrm{~km}^{2}$ (Table 2) and have an estimated volume of almost $400 \mathrm{~km}^{3}$ (Huss and Farinotti, 2012; Andreassen et al., 2015). From historical documents such as paintings and photography (Zumbühl et al., 2008), it is clear that glaciers have undergone substantial mass loss since the 19th century (Fig. 2) and that the pace of mass loss has been increasing (Zemp et al., 2015). A loss of $49 \%$ in the ice volume was estimated for the European Alps for the period 1900-2011 (Huss, 2012). Repeat inventories have shown a reduction in glacier area of $11 \%$ in Norway between 1960 and the 2000s $\left(-0.28 \% \mathrm{yr}^{-1}\right)$ (Winsvold et al., 2014) and $28 \%$ in Switzerland between 1973 and $2010\left(-0.76 \% \mathrm{yr}^{-1}\right)$ (Fischer et al., 2014). Periods with positive surface mass balance have, however, occurred intermittently, notably from the 1960s to the mid-1980s in the Alps and in the 1990s and 2000s for maritime glaciers in Norway (Zemp et al., 2015; Andreassen et al., 2016). Glacier area loss has led to the disintegration of many glaciers, which has also affected the observational network (e.g., Zemp et al., 2009; Carturan et al., 2016). In the more southerly parts of Europe, glacier retreat in Pyrenees has accelerated since the 1980s and the small glaciers 
Table 2. Distribution of glacier area and volume in continental Europe and mainland Scandinavia. Years of reference and respective publications are given for the glacier area. Ice volume estimates refer to 2003 for continental Europe and Sweden (Huss and Farinotti, 2012) and to 1999-2006 for Norway (Andreassen et al., 2015). Uncertainties in ice volume are on the order of 10-20\%.

\begin{tabular}{lrrll}
\hline Country & Area $\left(\mathrm{km}^{2}\right)$ & Volume $\left(\mathrm{km}^{3}\right)$ & Year & Reference \\
\hline Norway & 2692 & 271 & $1999-2006$ & Andreassen et al. (2012b) \\
Sweden & 262 & 12 & 2002 & Brown and Hansson (2004) \\
Switzerland & 943 & 67 & $2008-2011$ & Fischer et al. (2014) \\
Austria & 415 & 17 & 2006 & Abermann et al. (2009) \\
Italy & 370 & 18 & $2005-2011$ & Smiraglia and Diolaiuti (2015) \\
France (Alps) & 275 & 13 & $2006-2009$ & Gardent et al. (2014) \\
France-Spain Pyrenees & 3 & $<1$ & 2011 & Marti et al. (2015) \\
TOTAL & 4960 & 399 & & \\
\hline
\end{tabular}
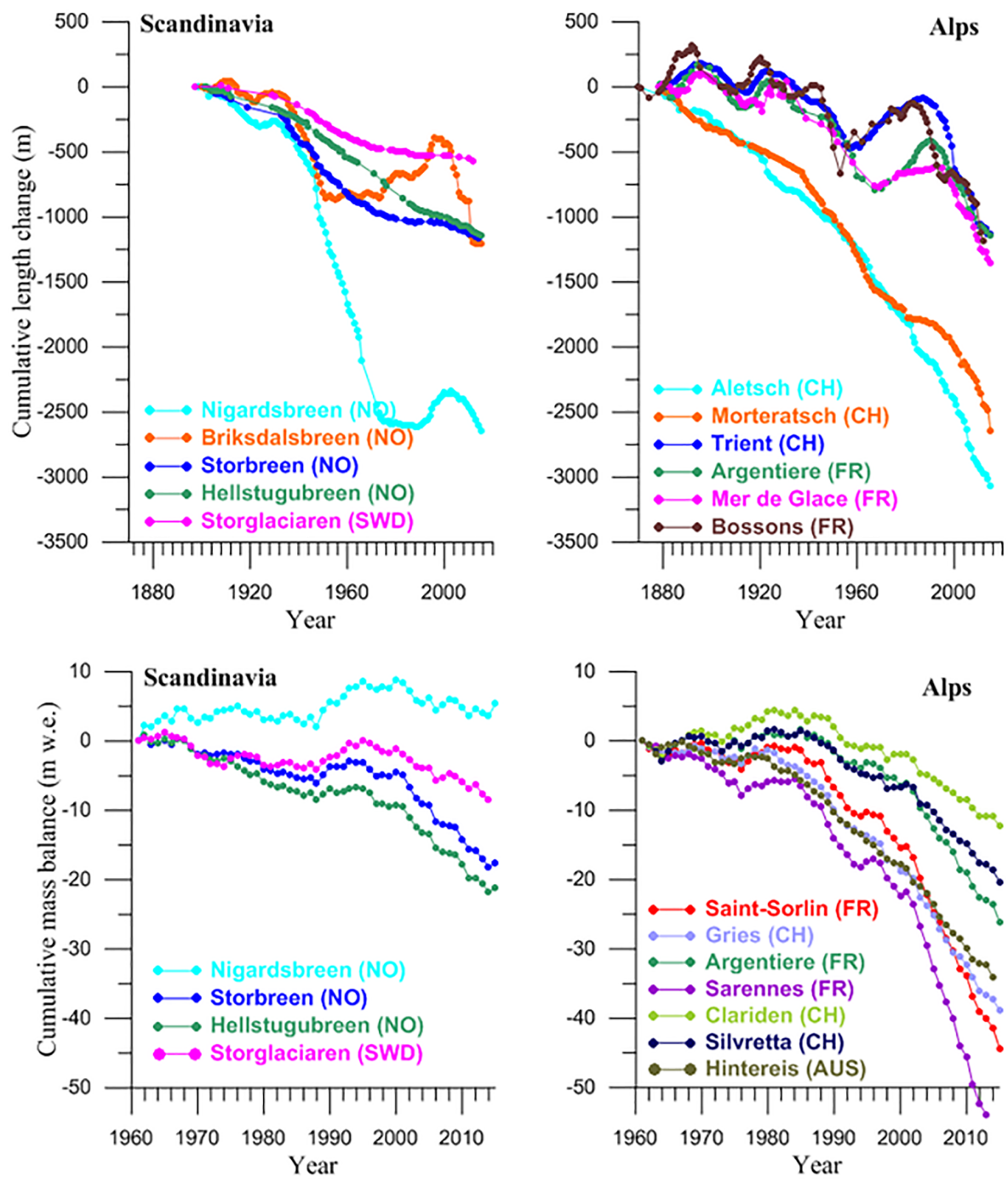

Figure 2. Length and surface mass balance changes documented with in situ measurements for glaciers in Scandinavia and in the European Alps. Sources: WGMS (2015) and earlier issues with updates (Andreassen et al., 2016).

are currently mostly in a critical situation (López-Moreno et al., 2016; Rico et al., 2017).
Glacier retreat during the 20th century has mainly been attributed to changes in atmospheric energy fluxes and associ- 
ated air temperature changes. A good correlation between air temperature and melt exists, making long-term air temperature time series the favorite option to explain 20th century glacier retreat (Haeberli and Beniston, 1998). High melt rates in the 1940s have, however, also been associated to changes in solar radiation (Huss et al., 2009). Several studies used calibrated temperature-index methods to simulate snow and ice melt responses to atmospheric forcing (Braithwaite and Olesen, 1989; Pellicciotti et al., 2005) although the appropriateness of such approaches for long-term studies has often been debated (Huss et al., 2009; Gabbi et al., 2014; Réveillet et al., 2017). Glacier response to atmospheric forcing is driven by different factors, ranging from synoptic weather patterns to local effects enhanced by topography. The latter influences, among others, the distribution of precipitation, solar radiation, and wind. Several studies have shown that glacier mass balance can be influenced by the NAO. Glacier advances in Scandinavia during 1989-1995, for example, are attributed to increased winter precipitation linked to the positive NAO phase during that period (Rasmussen and Conway, 2005). In the European Alps, the relationship between the NAO and glacier surface mass balance is less pronounced (Marzeion and Nesje, 2012; Thibert et al., 2013). This is essentially because the Alps are often a "pivotal zone" between southern and northern Europe, where the correlations between the NAO index and temperature or precipitation tend to be generally stronger (i.e., in the Mediterranean zone and in Scandinavia).

Glacier evolution during the 20th century also highlights the importance of the surface albedo feedback, as albedo governs the shortwave radiation budget at the glacier surface, which is the dominant energy source for melting. The sensitivity of ablation to albedo has generally been assessed using energy-balance considerations (Six and Vincent, 2014) or degree-day approaches (e.g., Pellicciotti et al., 2005). Oerlemans et al. (2009) and Gabbi et al. (2015) investigated the influence of accumulation of dust or black carbon on melt rates for Swiss glaciers in the last decades, revealing annual melt rates increased by $15-19 \%$ compared to pure snow. Monitoring, reconstructing, or modeling the surface albedo of glaciers is challenging (Brock et al., 2000) as its spatial and temporal evolution is linked to changes in surface properties (mainly snow grain size and grain shape) and to the deposition of impurities on the ice. Albedo changes are also determined by snow deposition (amount and spatial distribution), making the annual surface mass balance highly sensitive to snow accumulation (Réveillet et al., 2017). Properly quantifying the amount and distribution of accumulation over glaciers is therefore a key to better assess the glacier surface mass balance sensitivity to changes in climate and to simulate its future evolution (Sold et al., 2013).

Glacier dynamics are influenced by numerous variables such as mass change and basal hydrology for temperate glaciers and by ice temperature changes for cold glaciers. In temperate glaciers, ice dynamics is mainly driven by thick- ness changes and the basal hydrological system, which in turn affects basal sliding. The large decrease in ice thicknesses over the last three decades has led to a strong reduction in ice flow velocities (Berthier and Vincent, 2012). Increased water pressure, in contrast, reduces the frictional drag and thus increases the sliding rate. Sliding velocities are low when the water under glaciers drains through channels at low pressure and high when the water drains through interconnected cavities (Röthlisberger, 1972; Schoof, 2010). Although changes in seasonal ice flow velocities are driven by subglacial hydrology, it seems that, at the annual to multiannual timescales, the ice flow velocity changes do not depend on changes in subglacial runoff (Vincent and Moreau, 2016). A few temperate alpine glaciers, such as the Belvedere Glacier in Italy, have shown large accelerations due to a change in subglacial hydrology (Haeberli et al., 2002), whereby the mechanisms of this surge-type movement remain unclear. In some rare cases, the reduction of the efficiency of the drainage network followed by a pulse of subglacial water triggered a catastrophic break-off event as in the case of Allalingletscher in 1965 and 2000 (Faillettaz et al., 2015).

Studies of cold glaciers in the Monte Rosa and Mont Blanc area revealed that englacial temperatures have strongly increased over the last three decades due to rising air temperatures and latent heat released by surface meltwater refreezing within the glacier (Lüthi and Funk, 2000; Hoelzle et al., 2011; Gilbert et al., 2014). A progressive warming of the ice is expected to occur and propagate downstream. As a result, changes of basal conditions could have large consequences on the stability of hanging glaciers (Gilbert et al., 2014). Such changes in basal conditions are understood to be responsible for, e.g., the complete break-off of Altels Glacier in 1895 (Faillettaz et al., 2015).

\subsubsection{Future evolution of European glaciers}

Over the last two decades, various studies on potential future glacier retreat in Europe have been published. These can be broadly classified into site-specific (e.g., Giesen and Oerlemans, 2010) and regional studies (e.g., Salzmann et al., 2012). Methods range from simple extrapolation of past surface or length changes to complex modeling of glacier mass balance and ice flow dynamics. Similarly, applied models range from simple degree-day approaches (e.g., Braithwaite and Zhang, 1999; Radic and Hock, 2006; Engelhardt et al., 2015) to complete surface energy-balance formulations (e.g., Gerbaux et al., 2005) or from simple parameterizations of glacier geometry change (Zemp et al., 2006; Huss et al., 2010; Linsbauer et al., 2013), over flow line models (e.g., Oerlemans, 1997; Oerlemans et al., 1998), to three-dimensional ice flow models solving the full Stokes equations (Le Meur et al., 2004; Jouvet et al., 2011; Zekollari et al., 2014). All models indicate a substantial reduction of glacier ice volume in the European Alps and Scan- 
(a)

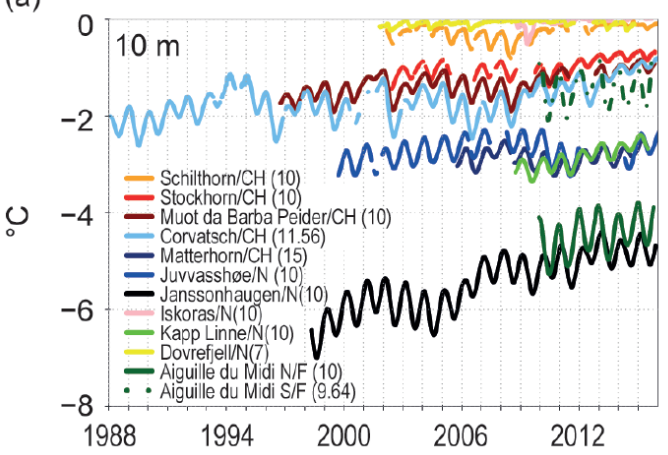

(b)

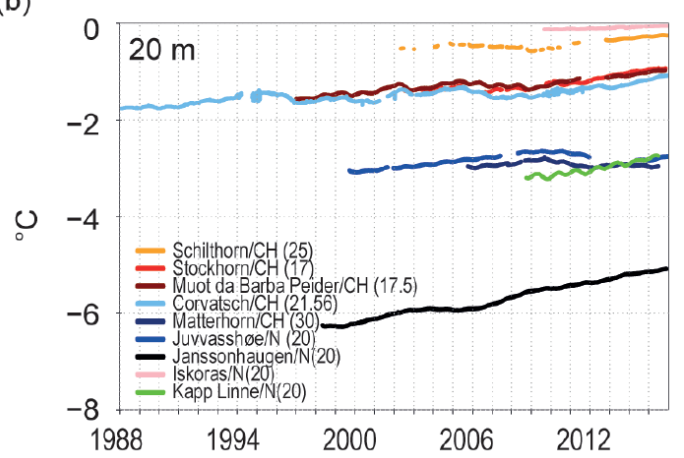

Figure 3. Temperature evolution of mountain permafrost in Norway $(\mathrm{N})$, France $(\mathrm{F})$, and Switzerland $(\mathrm{CH})$ measured in boreholes at $10 \mathrm{~m}(\mathbf{a})$ and $20 \mathrm{~m}$ (b) depth (exact depth given in the parentheses). Adapted from Noetzli et al. (2016).

dinavia by the end of the century. Small glaciers are likely to completely disappear (Linsbauer et al., 2013), and even large valley glaciers, such as Great Aletsch Glacier, Rhône Glacier, Morteratsch Glacier (Switzerland), or ice caps such as Hardangerjøkulen and Spørteggbreen (Norway), are expected to lose up to $90 \%$ of their current volume (Jouvet et al., 2009, 2011; Giesen and Oerlemans, 2010; Farinotti et al., 2012; Laumann and Nesje, 2014; Zekollari et al., 2014; Åkesson et al., 2017). Many glacier tongues will disappear, including the one from Briksdalsbreen, the outlet glacier of mainland Europe's largest ice cap Jostedalsbreen (Laumann and Nesje, 2009).

At the scale of mountain ranges, model studies relying on medium-range emission scenarios consistently predict relative volume losses of 76-97\% for the European Alps and of 64-81 \% for Scandinavia (Marzeion et al., 2012; Radic et al., 2014; Huss and Hock, 2015) for the 21st century. Since the mountain glaciers in Europe are far out of balance with the present climate (e.g., Andreassen et al., 2012a; Mernild et al., 2013), such volume losses must be expected even with strong efforts to reduce $\mathrm{CO}_{2}$ emissions and to stabilize global warming at less than $+2{ }^{\circ} \mathrm{C}$ as recommended by the Paris COP-21 climate accord (Huss, 2012; Salzmann et al., 2012). Due to their limited altitudinal extent, many glaciers are unable to reach a new equilibrium with climate even if air temperatures were stabilized by the end of this century. Furthermore, ice caps in Norway that contribute to a large part of the total ice volume in Europe (Table 2) are highly sensitive to mass balance-altitude feedback due to their hypsometry and large ice thicknesses. Model experiments suggest that Hardangerjøkulen will not regrow with its present mass balance regime once it has disappeared (Åkesson, 2017). However, uncertainties in projections of future glacier evolution are still considerable and improvements are required in both the quality of the input data and the physical basis upon which glaciological models are built (see Sect. 3.1).

\subsection{Changes in permafrost}

Permafrost is defined as lithospheric material with temperatures continuously below $0{ }^{\circ} \mathrm{C}$ and covers approximately 20 million $\mathrm{km}^{2}$ of Earth's surface, with a fourth of it being located in mountainous terrain (Gruber, 2012). Although the understanding of the thermal state of permafrost has increased significantly within the recent past, knowledge gaps still exist regarding the volume of permafrost ice stored in Europe, its potential impact on future water resources, and its effect on slope stability, including processes leading to permafrost degradation and talik formation (Harris et al., 2009; Etzelmüller, 2013; Haeberli, 2013).

\subsubsection{Observed changes in permafrost and in rock-glacier flow velocities and ice volume}

Permafrost borehole temperatures are monitored in many European mountain ranges (documented and available in the Global Terrestrial Network for Permafrost (GTN-P) database; Biskaborn et al., 2015), several of the sites being accompanied by meteorological stations and ground surface temperature measurements (Gisnås et al., 2014; Staub et al., 2016). However, as mountain permafrost is usually invisible from the surface, various indirect methods need to be employed to detect, characterize, and monitor permafrost occurrences. These methods include surface-based geophysical measurements to determine the physical properties of the subsurface, including water and ice content distributions (Kneisel et al., 2008; Hauck, 2013), and geodetic and kinematic measurements to detect subsidence, creep, and slope instabilities (Kääb, 2008; Lugon and Stoffel, 2010; Kaufmann, 2012; Kenner et al., 2014; Arenson et al., 2016).

The longest time series of borehole temperatures in Europe started in 1987 at the Murtèl-Corvatsch rock glacier in the Swiss Alps (Haeberli et al., 1998; Fig. 3), a period that is much shorter compared to the available ones for the other cryospheric components such as snow (see Sect. 2.1) or glaciers (see Sect. 2.2). The past evolution of permafrost 
at centennial timescales can to some extent be reconstructed from temperature profiles in deep permafrost boreholes (e.g., Isaksen et al., 2007), pointing to decadal warming rates at the permafrost table on the order of $0.04-0.07^{\circ} \mathrm{C}$ for Northern Scandinavia. Permafrost has been warming globally since the beginning of the measurements (Romanovsky et al., 2010; Noetzli et al., 2016; Fig. 3). This warming was accompanied by an increase of the thickness of the seasonal thaw layer (hereafter referred to as the active layer; Noetzli et al., 2016). The considerable year-to-year variability can be linked to variations in the snow cover, as a reduction in snow cover thickness reduces thermal insulation. Latent heat effects associated with thawing mask the recent warming trend for "warm" permafrost sites (temperatures close to the freezing point), which is otherwise clearly visible in cold permafrost (see Fig. 3).

The increasing trend in permafrost temperatures and especially the deepening of the active layer has been hypothesized to lead to an increased frequency of slope instabilities in mountain ranges, including debris flows and rockfalls (Gruber and Haeberli, 2009; Harris et al., 2009; Bommer et al., 2010; Stoffel, 2010; Fischer et al., 2012; Etzelmüller, 2013; Stoffel et al., 2014a, b). The disposition conditions and triggering mechanisms of slope instabilities can be diverse and depend on subsurface material (e.g., unconsolidated sediments vs. bedrock), its characteristics (fractures and fissures, ice and water content, slope angle, geological layering), and changes of these properties with time (Hasler et al., 2012; Krautblatter et al., 2012; Ravanel et al., 2013; Phillips et al., 2017). Water infiltration into newly thawed parts of permafrost is often mentioned as a possible triggering mechanism (Hasler et al., 2012), but only few observational data are available to confirm this hypothesis. By means of treering reconstructions (Stoffel et al., 2010; Stoffel and Corona, 2014), the temporal evolution of debris-flow frequencies has been addressed for a series of high-elevation catchments in the Swiss Alps. These studies point to increased debris-flow activity as a result of climate warming since the end of the Little Ice Age (Stoffel et al., 2008; Bollschweiler and Stoffel, 2010a, b; Schneuwly-Bollschweiler and Stoffel, 2012) and a dependence of debris-flow magnitudes due to instabilities in the permafrost bodies at the source areas of debris flows (Lugon and Stoffel, 2010; Stoffel, 2010).

Several studies have documented recent events of rock slope failures in the Alps (Ravanel et al., 2010; Ravanel and Deline, 2011; Huggel et al., 2012; Allen and Huggel, 2013). Some of these failures are clearly related to deglaciation processes (Fischer et al., 2012; Korup et al., 2012; Strozzi et al., 2010). Unusually high air temperatures have additionally been associated with these processes as the penetration of meltwater from snow and ice into cleft systems results in a reduction of shear strength and enhanced slope deformation (Hasler et al., 2012). Considering the multiple factors that affect rock slope stability, however, it is generally difficult to attribute individual events to a single one (Huggel et al., 2013). Improved integrative assessments are therefore necessary.

Further evidence of climatic impacts on high mountain rock slope stability comes from the analysis of historical events. For the Alps, inventories documenting such events exist since 1990 (Ravanel and Deline, 2011; Huggel et al., 2012) and indicate a sharp increase in the number of events since 1990. This makes the temporal distribution of rock slope failures resembles the evolution of mean annual temperatures. Given the fact that monitoring and documentation efforts have been intensified during the past decades, it remains unclear to which degree this correlation is affected by varying temporal completeness of the underlying datasets.

Data on the ice volume stored in permafrost and rock glaciers are still scarce. To date, hydrologically oriented permafrost studies have been utilizing remote-sensing and meteorological data for larger areas or have had a regionally constrained scope such as the Andes (Schrott, 1996; Brenning, 2005; Arenson and Jacob, 2010; Rangecroft et al., 2015), the Sierra Nevada (Millar et al., 2013) or Central Asia (Sorg et al., 2015; Gao et al., 2016). To our knowledge, no systematic studies exist on permafrost-hydrology interactions for the European mountain ranges to date.

In site-specific model studies, subsurface data are only available from borehole drillings and geophysical surveying. The models used often have originated from high-resolution hydrological models (e.g., GEOtop; Endrizzi et al., 2014), soil models (e.g., COUP model; Jansson, 2012; Marmy et al., 2016), or snow models (such as Alpine3D/Snowpack; Lehning et al., 2006; Haberkorn et al., 2017) and have been successfully extended to simulate permafrost processes. Recently, explicit permafrost models have been developed as well (e.g., Cryogrid 3; Westermann et al., 2016).

Because of its complexity, permafrost evolution cannot be assessed by thermal monitoring alone. Kinematic and geophysical techniques are required for detailed process studies. Kinematic methods are used to monitor moving permafrost bodies (e.g., rock glaciers) and surface geometry changes. Hereby, methods based on remote sensing allow for kinematic analyses over large scales (Barboux et al., 2014, 2015; Necsoiu et al., 2016) and the compilation of rock-glacier inventories (e.g., Schmid et al., 2015), whereas ground-based and airborne kinematic methods focus on localized regions and on the detection of permafrost degradation over longer timescales (Kaufmann, 2012; Klug et al., 2012; Barboux et al., 2014; Müller et al., 2014; Kenner et al., 2014, 2016; Wirz et al., 2014, 2016). Long-term monitoring of creeping permafrost bodies shows an acceleration in motion during recent years, possibly related to increasing ground temperatures and higher internal water content (Delaloye et al., 2008; Ikeda et al., 2008; Permos, 2016; Scotti et al., 2016; Hartl et al., 2016). The kinematic monitoring methods mentioned above, however, cannot be used for monitoring of permafrost bodies without movement or surface deformation (e.g., sediments with medium to low ice contents, rock plateaus, gentle 
rock slopes). Remote sensing has so far not enabled thermal changes in permafrost to be assessed.

Geophysical methods can detect permafrost and characterize its subsurface ice and water contents (Kneisel et al., 2008; Hauck, 2013). They also provide structural information such as active layer and bedrock depths. In recent years, repeated geoelectrical surveys have been applied to determine ice and water content changes, thus complementing temperature monitoring in boreholes (Hilbich et al., 2008a; Pellet et al., 2016). Results from such electrical resistivity tomography (ERT) monitoring show that permafrost thaw in mountainous terrain is often accompanied by a drying of the subsurface, as the water from the melted permafrost often leaves the system downslope and is not always substituted in the following summer (Hilbich et al., 2008a; Isaksen et al., 2011). A 15-year ERT time series from Schilthorn, Swiss Alps, shows for example a clear decreasing trend of electrical resistivity, corresponding to ice melt, throughout the entire profile below the active layer (Fig. 4). The corresponding temperature at $10 \mathrm{~m}$ depth is at the freezing point and shows no clear trend. ERT is increasingly used in operational permafrost monitoring networks to determine longterm changes in permafrost ice content (Hilbich et al., 2008b, 2011; Supper et al., 2014; Doetsch et al., 2015; Pogliotti et al., 2015).

\subsubsection{Future evolution of European permafrost}

Physically based models of varying complexity are employed for process studies of permafrost (for a review see Riseborough et al., 2008; Etzelmüller, 2013) and specifically for the analysis of future permafrost evolution. These models should not be confused with permafrost distribution models (Boeckli et al., 2012; Gisnaas et al., 2016; Deluigi et al., 2017), which are statistical and often based on rockglacier inventories and/or topo-climatic variables such as potential incoming solar radiation and mean annual air temperature. Physically based site-level models are used in combination with regional climate models (RCMs) for studies of long-term permafrost evolution (Farbrot et al., 2013; Scherler et al., 2013; Westermann et al., 2013; Marmy et al., 2016), similar to land-surface schemes used for hemispheric permafrost modeling (Ekici et al., 2015; Chadburn et al., 2015; Peng et al., 2016). Physically based models are also used to explain the existence of low-altitude permafrost occurrences (Wicky and Hauck, 2017) and to analyze the dominant processes for the future evolution of specific permafrost occurrences in the European mountains (Scherler et al., 2014; Fiddes et al., 2015; Zhou et al., 2015; Haberkorn et al., 2017; Lüthi et al., 2017). Simulations for different mountain ranges in Europe suggest an overall permafrost warming and a deepening of the active layer until the end of the century (see Fig. 5 for four examples from the Swiss Alps; similar simulations from Scandinavia are found in Hipp et al., 2012; Westermann et al., 2013, 2015; Farbrot et al., 2013).
The projected increase in permafrost temperatures is mainly due to the anticipated increase in air temperatures. The latter also causes the snow cover duration to decrease, thereby reducing the thermal insulation effect (Scherler et al., 2013; Marmy et al., 2016). In spite of similar trends in RCM-driven permafrost studies, comprehensive regionalscale maps or trends for projected permafrost changes in Europe are not available to date. This is partly because of the insufficient borehole data, but mainly because of the large heterogeneity of the permafrost in European mountain ranges. The latter strongly depends on surface and subsurface characteristics (e.g., fractured and unfractured rock, fine and coarse-grained sediments, porosity), microclimatic factors (snow cover, energy balance of the whole atmosphereactive layer system, convection in the active layer, etc.), and topo-climatic factors (elevation, aspect, slope angle).

The largest and most important impacts related to permafrost thawing have yet to occur. Along with changes in precipitation, permafrost thawing is projected to affect the frequency and magnitude of mass wasting processes in mountain environments (IPCC, 2012). This is especially true for processes driven by water, such as debris flows (Stoffel and Huggel, 2012; Borga et al., 2014). Based on statistically downscaled RCM data and an assessment of sediment availability, Stoffel et al. (2011, 2014a, b) concluded that the temporal frequency of debris flows is unlikely to change significantly by the mid-21st century, but is likely to decrease during the second part of the century, especially in summer. At the same time, the magnitude of events might increase due to larger sediment availability. This is particularly true in summer and autumn when the active layer of the permafrost bodies is largest, thus allowing for large volumes of sediment to be mobilized (Lugon and Stoffel, 2010). Accelerations of rock-glacier bodies might play an additional role (Stoffel and Huggel, 2012). Providing projections for future sediment availability and release for areas that are experiencing permafrost degradation and glacier retreat is particularly important in the European Alps, where the exposure of people and infrastructure to hazards related to mass movements is high (Haeberli, 2013).

Finally, it should be noted that in contrast to glacier melting, permafrost thawing is an extremely slow process (due to the slow downward propagation of a thermal signal to larger depths and additional latent heat effects). As permafrost in European mountains is often as thick as $100 \mathrm{~m}$, a complete degradation is therefore unlikely within this century.

\subsection{Changes in meltwater hydrology}

In spring, summer, and autumn, seasonal snow and glacier ice are released as meltwater into the headwaters of the alpine water systems. Because of the temporally shifted release of water previously stored as snow and ice and the significant surplus of precipitation compared to the forelands, mountains have often been referred to as "water towers" (Moun- 

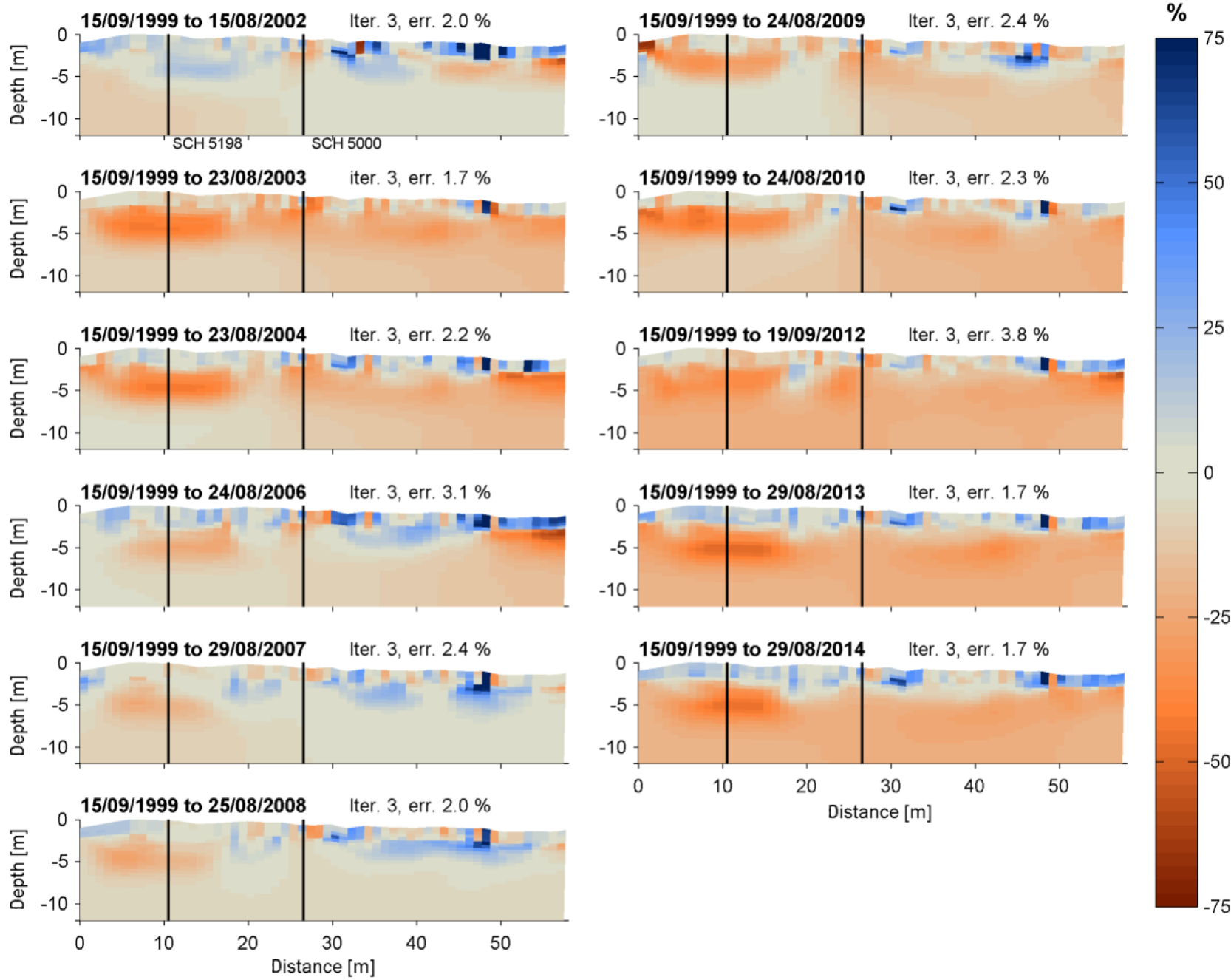

Figure 4. 15-year change in specific electrical resistivity (given as \% specific resistivity change) along a two-dimensional electrical resistivity tomography (ERT) profile at Schilthorn, Swiss Alps (2900 ma.s.1.). Red colors denote a resistivity decrease corresponding to loss of ground ice with respect to the initial measurement in 1999 (see Hilbich et al., 2008a, 2011, for more details on ERT monitoring in permafrost). The black vertical lines denote borehole locations (modified after Permos, 2016).

tain Agenda, 1998; Viviroli et al., 2007). The meltwater contribution to streamflow is important for millions of people downstream (Kaser et al., 2010). The Alps, in particular, are the water source for important rivers that flow into the North Sea (Rhine), the Black Sea (Danube), and the Mediterranean Sea (Rhône and Po); a comprehensive overview of the major alpine water systems is given in EEA (2009).

The most important seasonal runoff signal in the Alps is the melt of snow (Beniston, 2012). This is because the precipitation distribution is fairly even throughout the year and because the amount of water retained in and released from reservoirs and lakes is only a small fraction of the total water volume (Schaefli et al., 2007; López-Moreno et al., 2014). Temperature-induced changes in streamflow (such as rain-to-snow fraction, seasonal shift of snowmelt, and glacier runoff contribution) are generally better understood than the ones caused by changing spatiotemporal precipitation patterns (Blaschke et al., 2011). Nevertheless, understanding long-term trends in runoff requires an accurate estimate of the amount and distribution of snow accumulation during winter (Magnusson et al., 2011; Huss et al., 2014). The response of snowmelt to changes in air temperature and precipitation is influenced by the complex interactions between climatic conditions, topography, and wind redistribution of snow (López-Moreno et al., 2012; Lafaysse et al., 2014).

Several national assessments have addressed the hydrologic changes in alpine river water systems, highlighting important regional differences (FOEN, 2012; APCC, 2014); these reports contain a wealth of specific literature. Regional peculiarities are the result of spatial differences in temperature and precipitation changes, although other factors such as 

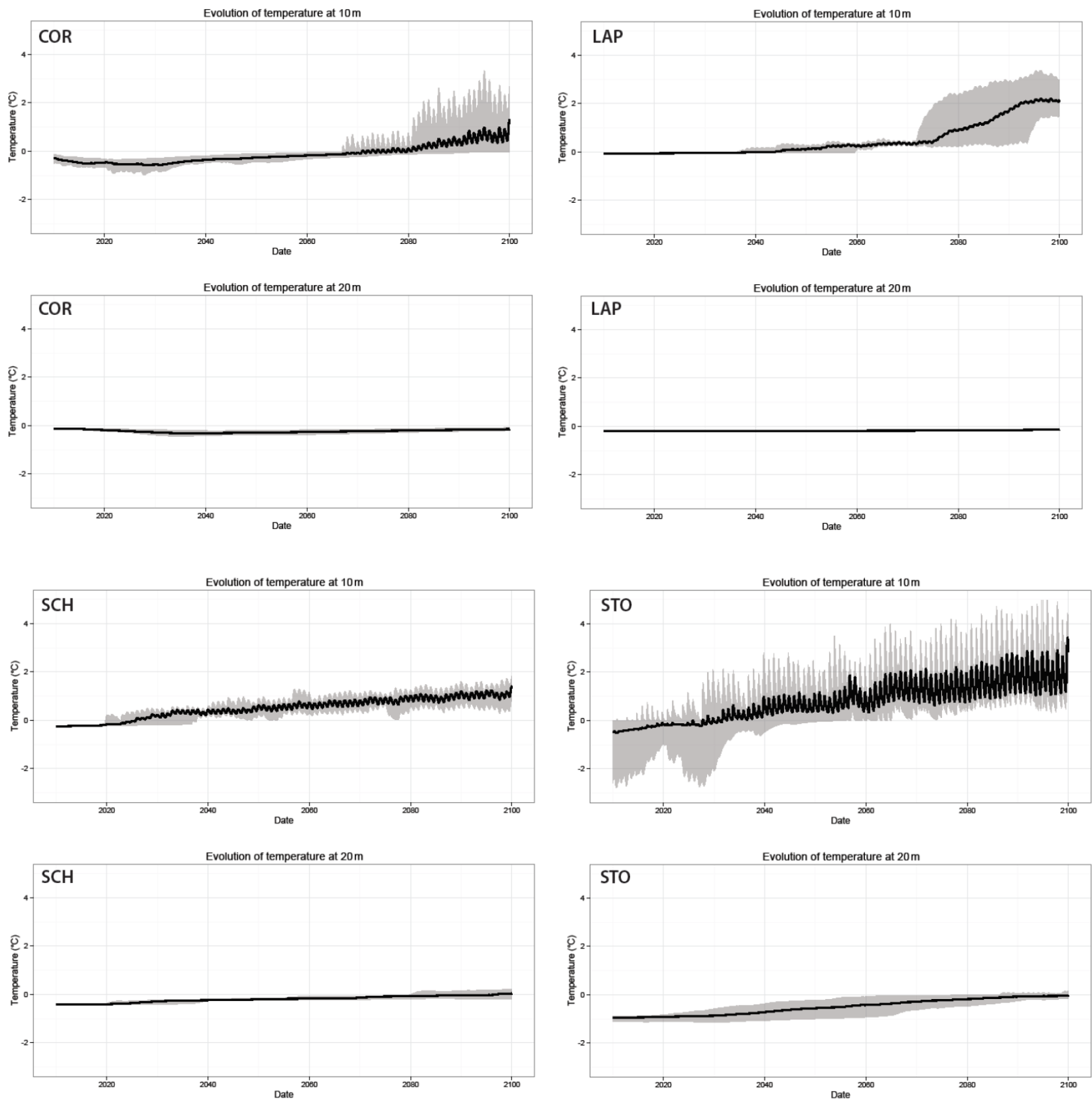

Figure 5. Modeled long-term evolution of ground temperatures at 10 and $20 \mathrm{~m}$ at four different permafrost sites in the Swiss Alps (COR: Murtèl-Corvatsch, LAP: Lapires, SCH: Schilthorn, STO: Stockhorn), as simulated with the COUP model (Marmy et al., 2016). The black lines represent the median scenario and the gray zone the range of the 13 GCM/RCM chains which were used to drive the simulations. Modified after Marmy et al. (2016).

local land-use changes or river corrections may play a role as well (EEA, 2004).

Compared to snowmelt, the total ice melt volume from glaciers in the Alps is minor. At subannual scales, however, contributions from glacierized surfaces can be significant not only for the headwater catchments close to the glaciers (Hanzer et al., 2016) but also for larger basins where glacier- ization is small (Huss, 2011). This is particularly true during summer when specific runoff yield from glacierized areas is much higher than from non-glacierized ones (Farinotti et al., 2016). In a warming climate with retreating glaciers this also holds for annual scales, as additional meltwater is released from ice storage that has accumulated over long time periods. 


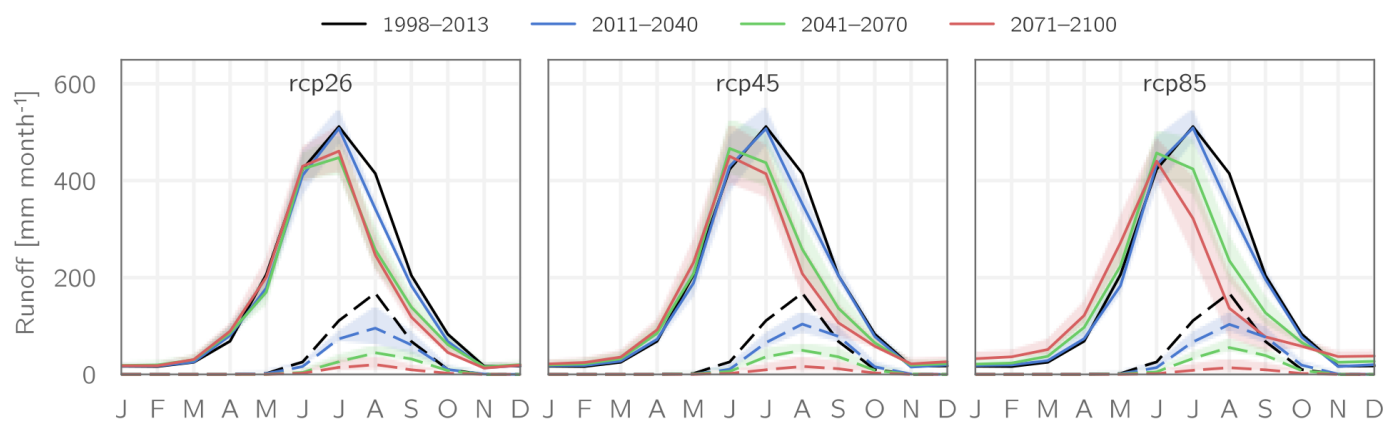

Figure 6. Shifts of streamflow regimes for the Rofenache catchment (Austrian Alps, 1891-3762 ma.s.1., $98 \mathrm{~km}^{2}$, $\sim 35 \%$ glacierization as of 2006) as simulated with the AMUNDSEN model using downscaled EURO-CORDEX projections for the RCP2.6, RCP4.5 and RCP8.5 scenarios. Solid and dashed lines indicate the multimodel mean total and ice melt runoff, respectively, and shaded bands indicate the climate model uncertainty shown as \pm 1 SD. Adapted from Hanzer et al. (2017).

In general, it can be stated that in large catchments the ice melt component in streamflow results from the contribution of many individual glaciers of varying size and setting. At the decadal or longer scale, the ice melt from these individual glaciers might be rising or declining, depending on glacier size and climatic trend, but as a result of the superposition of the many different contributions the resulting streamflow of a regional, glacierized catchment might not show a long-term trend, as has been simulated for the Rhine (KHR/CHR, 2016), for example. In this latter study, glaciers were considered according to a further developed $\delta \mathrm{h}$ method (Huss, 2010), allowing for both glacier retreat and transient glacier advances as required in long-term simulations: daily fractions of the rain, snowmelt, and glacier ice melt components of streamflow were determined for the Rhine basin from 1901 to 2006, with highest ice melt contributions during the periods with negative mass balances in the 1940s and 1980s.

Scenarios of changing streamflow affected by retreating glaciers in a warming climate have recently been developed in various physically based, distributed modeling experiments (Weber and Prasch, 2009; Prasch et al., 2011; Hanzer et al., 2017). Figure 6 illustrates future streamflow of a currently highly glacierized catchment (roughly $35 \%$ glacierization) in the Austrian Alps. Even for the moderate RCP2.6 scenario (IPCC, 2013), which corresponds roughly to the COP- 21 " $2{ }^{\circ} \mathrm{C}$ policy", the glacier melt contribution to runoff becomes very small by the end of the century. In the second half of the century, summer runoff amounts decrease strongly with simultaneously increasing spring runoff. While in the RCP2.6 scenario the month of peak runoff remains unchanged, RCP4.5 and RCP8.5 project the peak to gradually shift from July towards June. Alpine streamflow will hence undergo a regime shift from glacial/glacio-nival to nivo-glacial, i.e., the timing of maximum discharge will generally move from the summer months to spring (Beniston, 2003; Jansson et al., 2003; Collins, 2008; Farinotti et al., 2012; Prasch et al., 2011; Hanzer et al., 2017). For many streams utilized for hydropower generation, this phenomenon can be superimposed by the effects of discharge regulation. The regimes in Fig. 6 indicate that (a) the effect of warming increases after the middle of the century for all scenarios, (b) the effect is of the same order of magnitude as the one of the choice of climate model, and (c) the timing of the maximum contribution of ice melt to streamflow referred to as "peak water" - has already passed, i.e., that the effect of declining glacier area already overrides the increasing melt caused by rising temperatures. The time of occurrence for "peak water" mainly depends on the size of the glacier and can hence differ for adjacent catchments (Hanzer et al., 2017). Until the middle of the century and for large scales, the decrease of annual streamflow due to glacier retreat is expected to be small.

By 2100 , the glaciers in the Alps are projected to lose up to $90 \%$ of their current volume (Beniston, 2012; Pellicciotti et al., 2014; Hanzer et al., 2017). By then, peak discharge is likely to occur 1-2 months earlier in the year (Horton et al., 2006) depending on carbon-emission scenarios. In Switzerland, a new type of flow regime called "pluvial de transition" (transition to pluvial) was introduced to classify such newly emerging runoff patterns (SGHL/CHy, 2011; FOEN, 2012). Regime shifts have long been recognized and can be interpreted as the prolongation of observed time series - the longest one in the Alps being the recorded water level and streamflow discharge of the Rhine River in Basel since 1808. Some investigations, however, show that annual runoff totals may change only little, as the overall change resulting from reductions in snow and ice melt, changing precipitation, and increased evapotranspiration is unclear (SGHL/CHy, 2011; Prasch et al., 2011). Other studies, instead, highlight the significance of future regime shifts in headwater catchments (Pellicciotti et al., 2014). Obviously, the complex interplay of snow and ice melt contribution to discharge in a changing climate, combined with the other processes determining the streamflow regime, and their scale dependencies are not yet fully understood. There is general consensus that only 
a few high-altitude regions of the Alps will continue to have a glacial regime in the long term (FOEN, 2012). Further south in Europe, a loss of importance of snowmelt runoff in the last three decades has been detected for the majority of the mountain rivers in the Iberian Peninsula (MoránTejeda et al., 2014). For the Scandinavian mountains, the observed increase of runoff in winter and spring and the earlier snowmelt are projected for the future (RCP8.5), with relatively small changes of total annual runoff (NCCS 2017). This holds for all scenarios, with the changes being less in the moderate scenarios RCP4.5 and RCP2.6, respectively.

More than by changes in the cryosphere, hydrological extremes in the alpine region are affected by the changing climate itself. Periods of persistent and exceptional dry conditions have been identified based on a simple drought index around the mid-1940s and for the late 1850s to the 1870s (van der Schrier et al., 2006). For the 21st century, Heinrich et al. (2014) found increasing temperatures and negative trends of precipitation in the ENSEMBLES multimodel dataset (reference period 1961-1990), the latter mainly in the southern and eastern parts of the Alps (Brunetti et al., 2009). Drought conditions are expected to increase until the end of the 21 st century due to higher air temperatures, larger evapotranspiration rates, increased water use, and less precipitation (Calanca, 2007). The regions south of the Alps are thereby particularly affected.

Flood frequency has increased during the past 30 years in $20 \%$ of the river basins in Austria, mainly in small catchments north of the main Alpine ridge (Blöschl et al., 2013). For Switzerland, Allamano et al. (2009) found increasing flood peaks over the course of the last century, caused by increasing air temperature and precipitation. However, Schmocker-Fackel and Naef (2010) showed that this increase is comparable to known past periods of increased flood frequency, and apparent changes in flood frequency can also be attributable to construction measures in the river reaches and the loss of regulation reservoirs. In the future, summer floods might occur less frequently across the entire Alpine region since the frequency of wet days is projected to substantially decrease in summer (Rajcak et al., 2013). The magnitude and frequency of winter and spring floods, however, might increase due to higher intensity of extreme precipitation events in all seasons and for most regions in the Alps (Christensen and Christensen, 2007; Stoffel et al., 2016). In glacierized catchments, this effect adds to the regime shift with the streamflow maximum occurring earlier in spring after the moment of "peak water". Additionally, more frequent rain-on-snow (ROS) events can add to liquid precipitation if air temperatures continue to rise (Würzer et al., 2016, 2017).

Despite the general trend towards drier summers, indications for more frequent severe flooding due to heavy or extended precipitation events in the future have been found (Christensen and Christensen, 2007; Stoffel et al., 2016). Although summer floods might occur less frequently, the magnitude and frequency of winter and spring floods might in- crease since more frequent ROS events can add to liquid precipitation if air temperatures continue to rise (Würzer et al., 2016, 2017). It must be noted, however, that the severity and frequency of ROS events will tend to decrease in the future, not just because of rising temperatures but also when they become sufficiently warm to substantially reduce mountain snow cover and thus the potential for catastrophic consequences (Beniston and Stoffel, 2016). For the Scandinavian mountains, the recent tendency to increased frequency of rain floods is projected to continue and their magnitude to increase. Meltwater-induced floods, however, will decrease over time (NCCS 2017), which will enhance the deficit of soil moisture towards the end of the century. Many of the references discussed in the previous Sects. 2.1 (snow), 2.2 (glaciers), and 2.3 (permafrost) are of relevance here too.

Concerning droughts in the Alpine region, periods of persistent and exceptionally dry conditions have been identified around the mid-1940s and for the late 1850s to the 1870s (van der Schrier et al., 2006). In the future, drought conditions are expected to increase due to higher air temperatures, larger evapotranspiration rates, increased water use, and less precipitation (Calanca, 2007). The regions south of the Alps are thereby particularly affected. Further south in Europe, a loss of importance of snowmelt runoff in the last three decades has been detected for the majority of the mountain rivers in the Iberian Peninsula (Morán-Tejeda et al., 2014).

\subsection{Impacts on downstream water management}

Mountain agriculture, hydropower, and tourism are directly dependent on alpine headwaters and they will need to adapt to the changes in water availability and its seasonal distribution as a consequence of the decreasing role of snow and glacier melting in the hydrology as outlined in Sect. 2.4. Different scenarios therefore need to be considered, depending on how governance will cope with water-related conflicts that may arise from changes in water availability and demand (Nelson et al., 2007; Beniston et al., 2011a).

\subsubsection{Agriculture}

Shifts in agricultural production are expected with climate change as a consequence of higher water demand from crops and less water available due to higher temperatures and longer dry spells but also as a consequence of earlier snowmelt and less glacier contribution (Jaggard et al., 2010; Gornall et al., 2010). Most studies for Alpine regions project reduced soil water content as a result of increasing evaporation, thinner snowpack, and earlier snowmelt (Wu et al., 2015; Barnhart, 2016). This will lead to increased water demand for irrigation (Jasper et al., 2004; Schaldach et al., 2012; Riediger et al., 2014) and will add to the changes in water availability resulting from changing snow and glacier melt (Smith et al., 2014). The effects of more frequent climatic and hydrological droughts in the future (Gob- 
iet et al., 2014) will affect both croplands and grasslands. In Switzerland, the latter cover around $75 \%$ of the agricultural land and sustain domestic meat and dairy production (Fuhrer et al., 2006). The majority of crops currently cultivated in the Alps have been shown to be very sensitive to precipitation deficits in the growing season (Fuhrer et al., 2006; Smith et al., 2014). High irrigation demands will thus likely put additional pressure on rivers, especially small ones as they suffer more from interannual variability (Smith et al., 2012). Together with generally decreasing summer discharge, this will more frequently create low flow conditions which largely favor increasing water temperatures in streams with negative consequences for water quality and the aquatic fauna. Longterm water-management strategies will be important to face these challenges and to ensure that future agricultural water needs can be met (Riediger et al., 2014).

\subsubsection{Hydropower}

Climate change is a key driver in electricity markets, as both electricity production and demand are linked to weather and climate (Apadula et al., 2012). As a consequence of earlier snowmelt and reduced water discharge from glaciers, hydropower production potential is expected to increase in winter and spring and to decline in summer (Hauenstein, 2005; Kumar et al., 2011). Currently, energy demand is higher in winter than in summer, but this may change as rising summer temperatures increase energy requirements for the cooling of buildings (López-Moreno et al., 2008, 2011; Gaudard and Romerio, 2014). A study conducted for the Mattmark dam in the Swiss Alps and for the Val d'Aosta, Italy (Gaudard et al., 2014), revealed that peak hydropower production has so far not been affected by climate change. This is possibly the result of the large existing reservoir volumes which enable to offset seasonal changes (Farinotti et al., 2016). Indeed, it has been suggested that no urgent adaptation of the hydropower infrastructure will be required in Switzerland within the next 25 to 30 years (Haunstein, 2005). For Austria, little changes in annual hydropower production $( \pm 5 \%)$ have been projected up to 2050 using A1B SRES, but there could be a significan reduction in summertime power generation (Wagner et al., 2017). Reservoir management, however, will become more challenging as a consequence of higher fluctuations in electricity demands linked to the intermittent production of new renewable energy sources such as photovoltaic and wind power or biogas (Gaudard and Romerio, 2014). Furthermore, the interannual fluctuations in water availability are expected to increase (Gaudard et al., 2014). Run-of-river power plants are expected to be less vulnerable to climate change, as they are usually installed on streamflows with small hydrological fluctuations (Gaudard et al., 2014). Hydropower plants can also be effective in attenuating floods (Harrison and Whittington, 2001). Additional safety concerns include the melting of permafrost and the possibility of more frequent heavy rainfall, resulting in both more frequent slope instabilities and potential flood waves that may endanger power plants (Peizhen et al., 2001; Schwanghart et al., 2016). Increased sediment loads from deglacierized surfaces may additionally affect power generation, in particular by affecting the wear of infrastructure or the silting of storage volumes (Beniston, 2003).

\subsubsection{Winter tourism}

Increasing air temperatures are expected to result in shorter skiing seasons and a shift of the snow line to higher elevations (Abegg et al., 2007; Steiger, 2010). This will likely lead to smaller number of visitors and reduced revenues, and thus have important economic impacts on alpine winter tourism. Generation of artificial snow is designed to buffer the impact of interannual variability of snow conditions and is increasingly deployed in alpine ski resorts (Uhlmann et al., 2009; Steiger, 2010; Gilaberte et al., 2014; Spandre et al., 2016). In Switzerland, ski slope areas employing artificial snowmaking equipment have tripled (from 10 to $33 \%$ ) from 2000 to 2010 (Pütz et al., 2011). In the French Alps, $32 \%$ of the ski slope area was equipped with snow-making facilities in 2014, and this proportion is likely to reach $43 \%$ by 2020 (Spandre et al., 2015). In Austria, this share is about $60 \%$, mainly due to the lower average elevations of the Austrian ski areas, and in the Italian Alps almost $100 \%$ of the ski areas are equipped (Rixen et al., 2011). Water consumption for tourism in some Swiss municipalities is high compared to other uses. A study focusing on three tourism destinations in Switzerland, for example, found this consumption to be equivalent to $36 \%$ of the drinking water consumption (Rixen et al., 2011). Water and energy demands of ski resorts will increase, which may in turn lead to higher prices for consumers (Gilaberte et al., 2014). Also, summer mountain resorts could be affected by water shortages in the future, thus calling for adapted water management (Roson and Sartori, 2012).

\section{Challenges and issues for cryosphere research in European mountains}

In the following, we present four points that we consider to be crucial for the future development of cryospheric research. The points were identified with the European mountain cryosphere in mind but are mostly transferrable to other regions as well. The four points include (1) the numerical modeling of the cryosphere; (2) the understanding of cascading processes; (3) the quantification of precipitation and its phase changes; and (4) issues related to the acquisition, management, and sharing of observational data.

\subsection{Modeling of the cryosphere: spatial scales and physical processes in complex terrain}

For simulating the past, models of snow, glaciers, and permafrost critically rely on meteorological observations, from 
either station measurements, spatial interpolation of surface observations, or reanalyses, as forcing data. For future simulations, instead, climate models are used. As their current horizontal resolutions, typically in a range between hundreds and tens of kilometers, do not allow a reliable representation of small-scale processes, climate models are generally downscaled using dynamical, statistical, or stochastic downscaling techniques. The outputs are eventually adjusted to take into account model biases in mountain regions (Terzago et al., 2017; Kotlarsky et al., 2014) and then employed to force offline snow, glaciers, and permafrost models. A key point of such approach is to quantify the errors associated to each step of the procedure and to evaluate the propagation of the uncertainties along the modeling chain.

Concerning climate models, an important source of error in the mountainous areas is the coarse representation of the topography, the interaction between topography and atmospheric processes, and the altitudinal temperature gradients, which directly translate into a crude separation of the precipitation phase (Wilcox and Donner, 2007; Chen and Knutson, 2008; Wehner et al., 2010; Sillmann et al., 2013). Increased horizontal resolution (Boyle and Klein, 2010) and refinements in the representation of vertical processes - including convection and cloud microphysics (Kang et al., 2015) are important improvements to be achieved towards a better simulation of mountain processes.

The increasing availability of field data can help in refining the understanding of such processes through direct data-based inference (Diggle and Ribeiro, 2007) and assimilation techniques (Leisenring and Moradkhani, 2011). While such approaches are common to various fields of environmental sciences (e.g., Banerjee et al., 2003), applications in cryospheric research are still rarely found. This is, amongst other, because of some specific difficulties that include the existence of embedded spatial scales (Mott et al., 2011), strong vertical gradients (e.g., temperature, wind speed, phase of precipitation), and the nonlinearity linked phase transitions (Morán-Tejeda et al., 2013). To take full advantage of the ever increasing volume and variety of observational data, the development of adequate statistical models will also be required (Gilks et al., 2001; Wikle, 2003; Cappé et al., 2005). Separating space and time effects has been suggested to be the easiest way to address spatiotemporal data (Cressie and Wikle, 2011). However, temporal evolutions at small spatial scales cannot be inferred this way, so that the application of nonseparable spatiotemporal covariance models, for example, seem to have great potential (Gneiting et al., 2007; Genton and Kleiber, 2015).

\subsubsection{Snow modeling}

The snow pack is affected by a series of small-scale processes, including water transport in snow and firn (Würzer et al., 2017; Wever et al., 2014, 2016), phase changes (i.e., melt, refreezing, sublimation and condensation), drifting and blowing snow, and metamorphism (e.g., Aoki et al., 2011; Pinzer et al., 2012). While the mechanistic understanding of these processes at the point scale is rapidly increasing (Wever et al., 2014), challenges comes from quantifying their effects at larger scales. Examples of the interplay between large- and small-scale effects include the altered snow distribution after a storm (Lehning et al., 2008; Schirmer et al., 2009) or the change in snow albedo after a melt event. The underlying small-scale processes (such as snow-grain saltation and metamorphism in the case of wind redistribution and albedo changes, respectively) are reasonably understood at the point scale, but they are insufficiently represented or even neglected in large-scale models due to the lack of adequate upscaling schemes. Small-scale snow properties are also essential for the correct interpretation of remote-sensing signals. Ice lenses or the liquid water content in snow, for example, heavily influence the microwave backscatter, which could be used to infer large-scale SWE (Marshall et al., 2007). We argue that the challenges in snow modeling are currently scale dependent.

For modeling snow at the point scale and with a high level of detail, for example in snow stability estimates in the context of avalanche warning, two physically based models are mostly used: CROCUS (Vionnet et al., 2012) and SNOWPACK (Lehning et al., 1999). Nevertheless, many of the processes described in these models, such as metamorphism and mechanical properties, still have a high degree of empirical parameterization (Lehning et al., 2002). The main challenge for snow model development at this scale is the formulation of a consistent theory for snow microstructure (Krol and Lowe, 2016) and its metamorphism.

For hydrological applications, the catchment scale is the most relevant one (Kumar et al., 2013). Snow models of different complexity are used for this (Essery, 2015; Magnusson et al., 2015), and principal challenges are to (a) distinguish between uncertainties introduced by the model structure and uncertainties related to the input data (Schlögl et al., 2016) and (b) develop transferable, site-independent model formulations without the need of calibration. The latter is particularly important for reliable predictions of climate change effects (Bavay et al., 2013) and for model applications to ungauged catchments (Parajka et al., 2013).

Large-scale models, finally, use relatively simple, parametric snow schemes, as these require only a small set of input variables and are computationally less expensive (Bokhorst et al., 2016). Current numerical weather prediction systems generally use oversimplified single-layer snow schemes (IFS documentation, 2016; GFS documentation, 2016). Only in some rare cases do these models explicitly represent the liquid water content within the snowpack or incorporate a refined formulation for snow albedo variability (Dutra et al., 2010; Sultana et al., 2014). Climate models generally resolve the diurnal and seasonal variations of surface snow processes (i.e., surface temperature, heat fluxes) while they simplify the treatment of internal snow processes 
such as liquid water retention, percolation, and refreezing (Armstrong and Brun, 2008; Steger et al., 2013) or the evolution of snow microstructure due to metamorphism. Future research should clarify the degree of complexity required in snow schemes when integrated in large-scale climate models (van den Hurk et al., 2016).

\subsubsection{Permafrost modeling}

Challenges that need to be addressed in permafrost modeling include the development of (1) static large-scale permafrost distribution models, (2) high-resolution and site-specific permafrost evolution models, and (3) transient hemispheric permafrost models or land-surface schemes of RCMs and global climate models (GCMs). Current state-of-the-art permafrost distribution models (e.g., Gisnås et al., 2017) are forced not only by statistical and topo-climatic variables such as mean annual air temperature and potential incoming radiation but also by operationally gridded datasets of daily air temperature and snow cover. Statistical distributions of snow and other surface characteristics (soil type, roughness) allow for the representation of sub-grid variability of ground temperature (Gubler et al., 2011; Gisnås et al., 2014, 2016). However, the lack of spatial data on subsurface properties (thermal conductivity, porosity, ice content, etc.) prohibits a refined assessment of the permafrost distribution on catchment or local scales, at least for the discontinuous permafrost zone. Acquiring spatial data on subsurface properties as input and validation data is hereby one of the greatest current challenges in permafrost research (e.g., Hauck, 2013; Etzelmüller, 2013; Gubler et al., 2013).

Model intercomparison studies using uncalibrated model setup show that due to the abundance of permafrost-relevant processes in the atmosphere and at the snow surface and subsurface, a detailed simulation of permafrost processes on local scales is impossible without the availability of surface and subsurface data (Ekici et al., 2015). This results from the difficulty of correctly simulating phase changes and corresponding latent heat transfer in permafrost when the initial ground ice content is poorly known. Challenges in regional or hemispheric permafrost modeling therefore include numerical aspects and process-oriented model improvements, as well as data availability and up-scaling issues (Fiddes et al., 2015; Westermann et al., 2015). Most land-surface schemes of current GCMs and RCMs now include soil freezing schemes (e.g., McGuire et al., 2016). However, neither reliable ground ice content maps as input nor ground temperature maps for validation currently exist. Combined with the need for reliable snow, soil moisture, and vegetation data, this lack of subsurface information poses the largest uncertainties in estimates of current and future permafrost temperature and spatial distribution.

\subsubsection{Glacier modeling}

To increase the accuracy of glacier mass balance and runoff estimates, the distribution of ice volume and ice thickness is of primary importance. Glacier volume can be estimated from their surface area using scaling approaches (e.g., Bahr et al., 1997). However, such approaches do not provide the ice thickness distribution, which together with the surface mass balance controls the ice dynamics and the response of the glaciers to climate forcing. As it is currently impossible to measure ice thickness distributions of all glaciers individually, model applications are necessary. Several existing glacier models have been compared within the Ice Thickness Models Intercomparison eXperiment (ITMIX; Farinotti et al., 2017), revealing that (i) results largely depend on the quality of the input data (glacier outline, surface elevation, mass balance or velocities) and (ii) model complexity is not directly related to model performance. New high-resolution satellite images make the required input data available, thus opening the way toward improved future global estimates of glacier thicknesses.

Another challenge in glacier modeling is the use of approaches that explicitly consider ice dynamics. Jouvet et al. (2009) showed that full 3-D Stokes models representing ice flow without approximation can be applied if the required input data are available (e.g., glacier thickness, surface velocities). At the regional scale, however, simplified approaches are still required (Clarke et al., 2015). For estimating future glacier evolution, ice dynamics models need to be coupled to adequate representations of glacier surface mass balance. The Glacier Model Intercomparison Project (Glacier-MIP, www.climate-cryosphere.org/ activities/targeted/glaciermip) assesses the performance of regional- to global-scale glacier models to foster the improvement of the individual approaches and to reduce uncertainties in future projections. There are uncertainties in future meteorological variables and in their downscaling at the glacier scale. Some studies use degree-day approaches for long-term simulations (Réveillet et al., 2017) or account for potential radiation (Hock, 1999). However, with a change in the relative magnitude of energy fluxes at the glacier surface, calibrated degree-day factors are likely to change too. Application of models able to resolve the full energy balance are thus required (Hanzer et al., 2016). To be applicable, however, the accuracy and resolution of the corresponding input data need to be improved. More emphasis on the modeling of winter mass balances and the spatial distribution of snow accumulation (Réveillet et al., 2017), as well as the impact of supraglacial debris and related feedbacks (Reid and Brock, 2010), is required. The latter is particularly important as many glacier tongues become increasingly debris covered as they shrink. Feedback effects of black carbon and aerosols deposition on the glacier surface is also subject of study (Gabbi et al., 2015). Finally, more research on glacial sediment transport and erosion is needed as glacier 
retreat exposes large amounts of unconsolidated and erodible sediments that might - when entrained - represent a hazard downstream or reduce the efficiency of hydropower plants (Lane et al., 2016).

\subsubsection{Modeling uncertainty}

Predicting the future evolution of cryospheric components is challenging in many respects. On the one hand, these challenges stem from the incomplete understanding of the physical processes leading to given changes and from the lack of more comprehensive and consistent datasets (see Fig. 7). On the other hand, predictions are intrinsically affected by a range of uncertainties. Adequately evaluating and communicating such uncertainties is anything but a trivial task, both because the interplay between individual systems can be complex and because end users of projections are typically adverse to uncertainty. Outside the scientific community, "uncertainty" and "error" are two concepts often not sufficiently distinguished. This can lead to important misunderstanding and misinterpretations. Improving the way uncertainties are communicated is especially important when presenting scientific results to policymakers or stakeholders, as this can significantly affect the level of trust assigned to a particular finding.

\subsection{Cascading processes and process chains}

The projected increases in air temperatures imply enhanced melting of snow and ice. These, in turn, can lead to glacier recession and glacier debuttressing, an acceleration of creep in perennially frozen talus with high ice contents, and decreasing stability of steep, deeply frozen rock walls (Haeberli, 2013). Under certain conditions, new lakes will form in depressions left by receding glaciers (Haeberli and Linsbauer, 2013; Haeberli et al., 2016). The largest and most important impacts related to ongoing glacier wasting and permafrost thawing have yet to occur, with likely and potentially drastic impacts on the frequency and magnitude of mass wasting processes (such as rockfalls, rockslides, icefalls, debris flows) (IPCC, 2012). In high mountain environments, where relief energy is substantial, a single event can lead to a chain of reactions or cascading process, thereby greatly amplifying the magnitude of the original event. In the case of new lakes forming underneath hanging glaciers or at the foot of oversteepened and unstable rock slopes (Haeberli et al., 2010), for instance, mass movements into the lake could generate flood waves (Worni et al., 2014). These waves could overtop the lake dam, form a breach, and cause a downstream glacier lake outburst flood with discharges that could potentially be much larger than rainfall-induced floods (Schwanghart et al., 2016).

Another example of a process chain is the 2017 rockfall at Piz Cengalo (Grisons, Switzerland). In that case, the impact on a debris-covered glacier was suggested as a possible cause for the release of sufficient liquid water to transform part of the rockfall into a debris flow. The multiple debris flows, resulting from the 23 August 2017 rockfall, reached the village of Bondo, where they caused substantial damage to an area that would have remained unaffected in the absence of an amplifying chain of reactions. Other process cascades in the Swiss Alps include the assumed liquefaction of avalanche snow into debris flows in October 2011 during an intense ROS event (Morán-Tejeda et al., 2016). This resulted in massive damage in several regions of the Bernese and Valais Alps and at locations that were not affected by debris flows for decades.

The melting of glaciers and the increasing instability of permafrost bodies will possibly lead to the occurrence of mass movement events beyond historical experience, in terms of both frequency and magnitude (Stoffel and Huggel, 2012). If these processes occur as chain reactions, their consequences can be devastating for the downstream area. For the time being, however, the description of such cascades remains theoretical or anecdotal, and a general effort is required if such processes are to be better understood.

Models can be helpful in assessing the hazard potential of process chains and can provide important insights that would be difficult to obtain by observations alone. Although a number of numerical models have been developed to simulate different types of extreme mass movements, such modeling efforts still face challenges stemming from a lack of process understanding and the difficulty in measuring the necessary parameters in the field (Worni et al., 2014). In addition, current models were often conceived for the representation of single processes and are therefore inadequate for analyzing the interactions between processes involved during cascading events. Much effort is required to improve our understanding for how climate changes will affect alpine mass movements.

\subsection{Estimating liquid and solid precipitation in complex terrain}

Precipitation plays a key role in all cryospheric processes. When temperatures are close to or beneath the freezing point, precipitation determines the amount of snow accumulation and significantly influences the energy transfer within permafrost bodies. In its liquid form, instead, it can contribute to water storage within the snowpacks and in glaciers and steers direct water runoff.

At high elevations, large uncertainties affect the estimates of solid and liquid precipitation (Rasmussen et al., 2012). These uncertainties mainly arise from two facts: (a) the low density of precipitation gauges at high elevation (only $3 \%$ of stations worldwide are located above $2000 \mathrm{~m}$ a.s.l., and less than $1 \%$ above 3000 ma.s.1.; Pepin et al., 2015), which are the regions where cryospheric processes occur, and (b) the large bias in observations due to precipitation undercatch. The latter is on the order of $30 \%$ for high elevation (Adam and Lettenmeier, 2003; Yang et al., 2005) and is particu- 


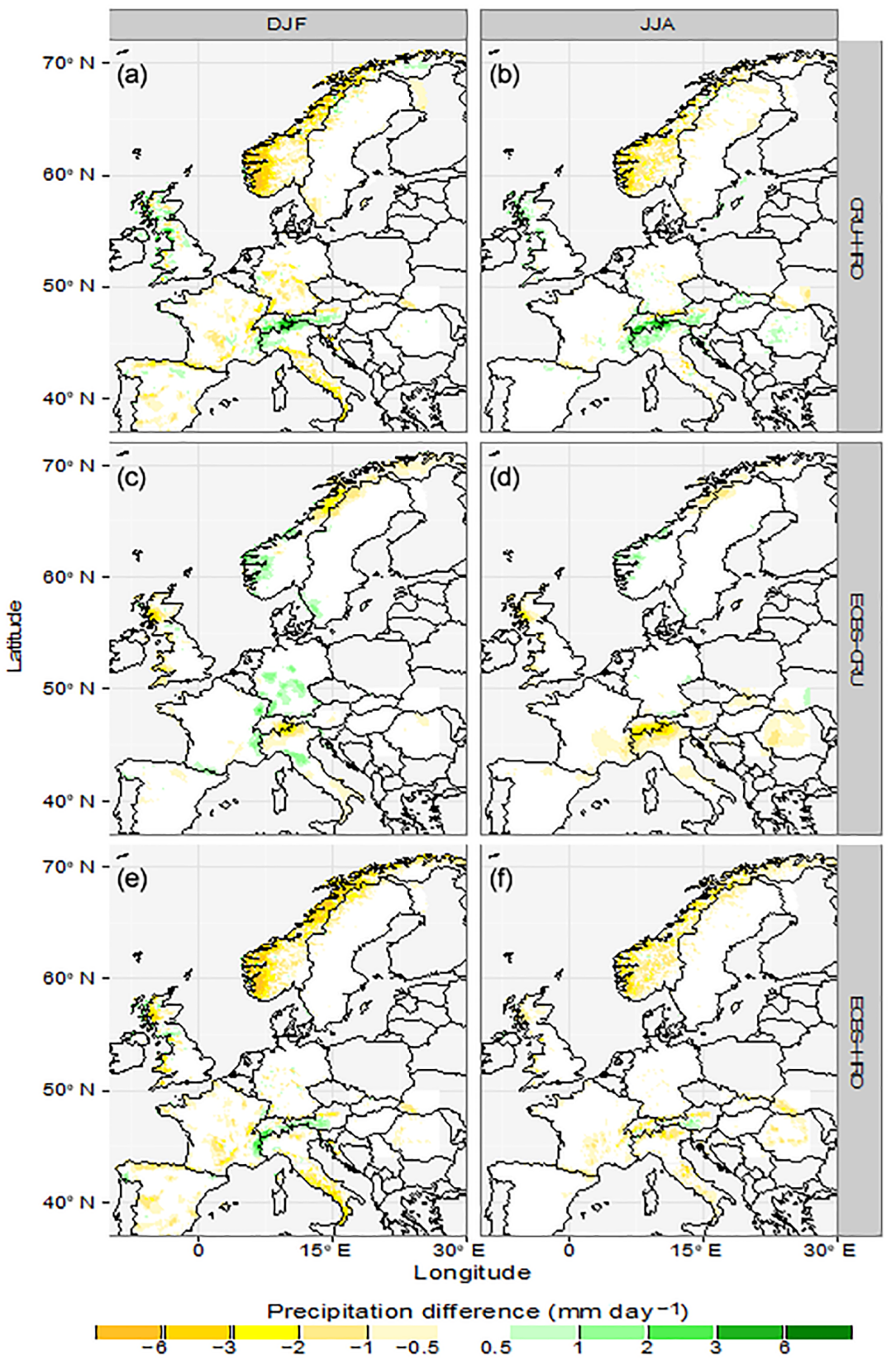

Figure 7. Seasonal average precipitation differences for December-January-February (DJF; a, c, e) and June-July-August (JJA; b, d, f) between CRU and HRO (a, b), E-OBS and CRU (c, d), and E-OBS and HRO (e, f). Acronyms are as follows: CRU is the Climatic Research Unit of the University of East Anglia; E-OBS is the ENSEMBLES daily gridded observational dataset; HRO indicates high-resolution observations (based on a network of local observations).

larly large for solid precipitation, since snowfall is importantly influenced by wind and since icing and riming affect the measurements. Efforts are currently ongoing to address these problems (e.g., Solid Precipitation Intercomparison Experiment (SPICE) by the World Meteorological Organization (WMO); Nitu et al., 2014), but reliable references for ground truth measurements still are not available.
Large uncertainties also exist in the spatial and temporal distribution of precipitation. The spatial distribution, in fact, is not only determined by synoptic systems but also strongly affected by topography (Mott et al., 2010). For snow, post-depositional transport such as creep, saltation, suspension, and avalanching additionally influence the spatial distribution. Recent progress in measuring snow distribution in mountains through terrestrial and laser scanning or radar, 
for example (Grunewald et al., 2010; Kirchner et al., 2014), has allowed for a better understanding of typical distribution patterns of alpine water resources (Grunewald et al., 2014). When combined with relations between snow depths and SWE (e.g., Jonas et al., 2009), such information can also be used to quantify winter precipitation totals (Scipion et al., 2013; Mott et al., 2014). The results have highlighted, however, that even in highly instrumented mountain ranges such as the Alps, precipitation is still very poorly quantified. The combination of weather modeling with advanced data assimilation techniques, including precipitation radar data, will lead to a more complete understanding of precipitation amounts in high mountains, and this is urgently required if future changes in precipitation are to be projected correctly. In this respect, climate modeling is called for continuing the efforts towards increased model resolution. For cryospheric research, achieving convection-resolving resolution is fundamental, since the process is fundamentally controlling the spatial distribution in high-alpine precipitation.

\subsection{Observational data: access, availability, quality, and spatial and temporal distribution}

Availability of observational data is a key for detecting, understanding, and projecting any environmental process (Beniston et al., 2012; Quevauviller et al., 2012). For cryospheric processes, at least two specific issues arise. First, additional efforts should be made to promote the long-term monitoring of key processes such as glacier retreat or permafrost thaw, for which high-quality, homogeneous, longterm observations are rare. In fact, at the moment, only a few long-term monitoring programs comprising meteorological, hydrological, and/or glaciological data collection exist, such as for the Oetztal Alps in Austria (Strasser et al., 2017). Second, ground-based observations of the cryosphere are affected by the difficulties in accessing the regions of interest (Klemes, 1990). Logistical challenges and related costs are introducing a bias in the availability of cryosphere-related observations. Even in European countries with reasonable financial and infrastructural resources, such observations have a bias towards low and mid-elevations and easily accessible regions. This also applies to related environmental variables, in particular meteorological variables (Orlowsky and Seneviratne, 2014). Substantial efforts and new technical solutions are required to improve the spatial coverage and representativeness of the variables of interest.

The high logistical and monetary costs of acquiring data at high elevations also explains why many cryosphere-related data across Europe still have restricted ownership. The consequences include lack of data, limitations to accessing existing data, delays in obtaining them, and duplication of datacollection efforts. The current push for open-data policies of major funding agencies (e.g., EC, ERC, NERC, ANR, DFG, $\mathrm{SNF}$ ) is therefore to be welcomed. Some examples for successful data portals related to cryospheric data include the
Global Earth Observation System of Systems (GEOSS) a data catalogue of a partnership of more than 100 states and the European Commission - the National Snow and Ice Data Center (NSIDC), the World Glacier Monitoring Service (WGMS), the International Network for Alpine Research Catchment Hydrology (GEWEX-INARCH), and the Swiss Open Support Platform for Environmental Research (OSPER). The recent establishment of a Global Cryospheric Watch program at the WMO facilitates the exchange of cryospheric data. To be successful, however, the definition of common standards for different data types is required, as well as adequate mechanisms for rewarding and acknowledging groups and agencies investing in field-data collection.

An effort towards rigorous open-data policies for the mountain cryosphere seems particularly important, since mountain topography often introduces sharp administrative boundaries such as country borders. The latter often impose artificial limitations in spatial coverage. Large-scale studies on snow cover changes based on in situ measurements, for instance, barely exist because such measurements are typically acquired from individual institutions or authorities. These cause the data to be subject to different jurisdictions, competences, practices, or priorities, all of which hamper free data exchange. Rather than adhering to administrative borders, environmental data should sample regions defined on the base of geomorphological, topographical, and climatologic considerations. We call upon the European community working in the domain of the mountain cryosphere to be an example when it comes to open-data policies.

\section{Conclusions}

This review has summarized prospects and challenges for future research in the European mountain cryosphere. It additionally provided an overview of past, current, and future changes in the fields of mountain snow, glaciers, and permafrost in the European mountains. The paper has attempted to address the current state of knowledge in terms of observed evolution and associated impacts. Within a few decades, these impacts will have a bearing on ecosystems and the services provided by them and on a number of economic sectors, including hydropower, agriculture, and tourism. The management of natural hazards will equally be affected, and a need for adaptation to climate change will arise.

A catalog of challenges for future cryospheric research has been identified, focusing on knowledge gaps, highresolution modeling, understandable communication of uncertainty, cascading mass movements and process chains, quantification of the spatiotemporal distribution of precipitation, and the availability and access of observational data. All these issues have effects on the capability of projecting future changes in the mountain cryosphere and the impacts that these changes are likely to generate. 
The principal challenges within the cryosphere domain include both issues specific to a sub-discipline and issues generally valid to several of them. The biggest overall challenge, however, is that the European mountain cryosphere is clearly expected to undergo drastic changes. European mountains will have a completely different appearance, most glaciers will have disappeared, and even the largest valley glaciers will have experienced significant retreat and mass loss. Seasonal snow lines will be found at much higher altitudes, and the snow season will be much shorter than today. The changes in snow and ice melt will cause a shift in the timing of discharge maxima and a transition towards pluvial regimes. This will in turn have significant impacts on the seasonality of water availability and consequences for water storage and management in reservoirs for drinking water and hydropower generation. Whereas an upward shift of the tree line and expansion of vegetation can be expected into current periglacial areas, the disappearance of permafrost at lower altitudes and its warming at higher elevations will likely result in mass movements and process chains beyond historical experience.

For future cryospheric research, the scientific community can build upon the awareness of these expected changes. Targeted strategies to precisely quantify the occurring changes and approaches capable of addressing and mitigating these changes are now required. Efforts are required not only in the monitoring of the associated processes but also in the numerical modeling of them. Current climate change scenarios predict the evolution of the components of the European cryosphere relatively reliably until 2050. In the second half of the century, however, the development is much more uncertain. This is linked to, inter alia, the uncertainties affecting future precipitation evolution. Shifts in air temperature and precipitation will clearly be significant drivers for future changes in the mountain cryosphere, but so will changes in shortwave and longwave radiation processes (related to greenhouse gas forcing, changes in moisture and clouds, etc.) that are also key drivers for glacier melting and permafrost thawing.

Besides the emphasis on challenges in the modeling domain and cascading mass movement processes and process chains, this paper has highlighted data issues. Indeed, there are numerous limits to data availability, related to spatial and temporal sparseness and restricted access. Financial and institutional barriers, as well as non-harmonized data policies, add to the problem. Mountain cryosphere research urgently needs open-access data of high quality for both understanding the functioning of the various elements and for building reliable models capable of projecting their evolution.

Continuous improvement of physical models and free access to high spatial and temporal resolution simulations are essential to furthering our understanding of feedbacks between the atmosphere, the hydrosphere, and the cryosphere and to translate greenhouse gas emissions scenarios into cryospheric impacts. The spatial resolution of GCMs is rapidly increasing, but much of the information still remains too coarse for mountain cryosphere research. Physically based, nested global-to-regional modeling techniques are expected to provide adequate data in the future but simulation results will remain highly dependent on the models' initial conditions. Providing an adequate observational data basis for this purpose is therefore of paramount importance.

Finally, communicating research results on climate and cryospheric science is a challenge in itself. In general, the imminence of climatic change is more convincing to a lay audience when changes become visible. A prominent example is the retreat of mountain glaciers, which can convincingly be brought to the public through repeated photography. In this sense, climate-induced changes in the cryosphere enable a unique and effective form of communication. More effort should be dedicated to illustrate how these changes can affect water resources, mountain ecosystems, natural hazards, and a wide range of related economic activities.

By highlighting the impacts of a changing cryosphere as climate evolves, this review has attempted to emphasize the central role of the cryosphere as a key element of environmental change in high mountains. To develop appropriate adaptation strategies to respond to the changes in climate, we anticipate an increasing need for knowledge on the cryosphere.

Data availability. Due to the broad range of topics - and the large amount of data that have been compiled - anyone interested in accessing the information used in the paper should contact the following lead authors:

- for snow, Ulrich Strasser, Austria, at ulrich.strasser@uibk.ac.at;

- for glaciers, Liss M. Andreassen, Norway, at lma@nve.no;

- for permafrost, Christian Hauck, Switzerland, at Christian.Hauck@unige.ch;

- for observational data, Hendrik Huwald, Switzerland, at Hendrik.Huwald@epfl.ch;

- for modeling issues, Silvia Terzago, Italy, at s.terzago@isac.cnr.it.

Competing interests. The authors declare that they have no conflict of interest.

Acknowledgements. The discussions that have been presented in this review reflect the current opinions of a body of scientists that came together at the international cryosphere workshop "From Process Understanding to Impacts and Adaptation", which took place in Riederalp (Valais Alps), Switzerland, 15-19 March 2016. The University of Geneva is sincerely acknowledged for the generous support of this meeting. The authors would also like to thank the reviewers for their numerous critical and constructive comments that have enabled significant improvements to the paper. 
Edited by: Ross Brown

Reviewed by: Wilfried Haeberli and two anonymous referees

\section{References}

Abegg, B., Agrawala, S., Crick, F., and de Montfalcon, A.: Climate change impacts and adaptation in winter tourism, in: Climate Change in the European Alps, OECD (Organisation for Economic Co-operation and Development), Paris, France, 2560, 2007.

Abermann, J., Lambrecht, A., Fischer, A., and Kuhn, M.: Quantifying changes and trends in glacier area and volume in the Austrian Ötztal Alps (1969-1997-2006), The Cryosphere, 3, 205215, https://doi.org/10.5194/tc-3-205-2009, 2009.

Åkesson, H., Nisancioglu, K. H., Giesen, R. H., and Morlighem, M.: Simulating the evolution of Hardangerjøkulen ice cap in southern Norway since the mid-Holocene and its sensitivity to climate change, The Cryosphere, 11, 281-302, https://doi.org/10.5194/tc-11-281-2017, 2017.

Allamano, P., Claps, P., and Laio, F.: Global warming increases flood risk in mountainous areas, Geophys. Res. Lett., 36, L24404, https://doi.org/10.1029/2009GL041395, 2009.

Allen, S. and Huggel, C.: Extremely warm temperatures as a potential cause of recent high mountain rockfall, Global Planet. Change, 107, 59-69, 2013.

Ancey, C. and Bain, V.: Dynamics of glide avalanches and snow gliding, Rev, Geophys., 53, 745-784, 2015.

Andreassen, L. M., Kjøllmoen, B., Rasmussen, A., Melvold, K., and Nordli, Ø.: Langfjordjøkelen, a rapidly shrinking glacier in northern Norway, J. Glaciol., 58, 581-593, https://doi.org/10.3189/2012JoG11J014, 2012a.

Andreassen, L. M., Winsvold, S. H., Paul, F., and Hausberg, J. E.: Inventory of Norwegian glaciers, NVE Report, Norwegian Water Resources and Energy Directorate, Oslo, Norway, 28, 236 pp., 2012 b.

Andreassen, L. M., Huss, M., Melvold, K., Elvehøy, H., and Winsvold, S. H.: Ice thickness measurements and volume estimates for glaciers in Norway, J. Glaciol., 61, 763-775, https://doi.org/10.3189/2015JoG14J161, 2015.

Andreassen, L. M., Elvehøy, H., Kjøllmoen, B., and Engeset, R. V.: Reanalysis of long-term series of glaciological and geodetic mass balance for 10 Norwegian glaciers, The Cryosphere, 10, 535552, https://doi.org/10.5194/tc-10-535-2016, 2016.

Aoki, T., Kuchiki, K., Niwano, M., Kodama, Y., Hosaka, M., and Tanaka, T.: Physically based snow albedo model for calculating broadband albedos and the solar heating profile in snowpack for general circulation models, J. Geophys. Res.-Atmos., 116, D11114, https://doi.org/10.1029/2010jd015507, 2011.

Apadula, F., Bassini, A., Elli, A., and Scapin, S.: Relationships between meteorological variables and monthly electricity demand, Appl. Energ., 98, 346-356, 2012.

APCC: Austrian Assessment Report 2014, Österreichischer Sachstandsbericht, Austrian Panel on Climate Change (APCC), Vienna, Austria, 2014.

Arenson, L. U. and Jakob, M.: The significance of rock glaciers in the dry Andes - a discussion of Azócar and Brenning (2010) and
Brenning and Azócar (2010), Permafrost Periglac., 21, 282-285, https://doi.org/10.1002/ppp.693, 2010.

Arenson, L. U., Kääb, A., and O'Sullivan, A.: Detection and analysis of ground deformation in permafrost environments, Permafrost Periglac., 27, 339-351, https://doi.org/10.1002/ppp.1932, 2016.

Armstrong, R. L. and Brun, E. (Eds.): Snow and Climate, Cambridge University Press, New York, USA, 222 pp., 2008.

Banerjee, S., Carlin, B., and Gelfand, A. E.: Hierarchical Modeling and Analysis for Spatial Data, Chapman \& Hall ed., Boca Raton, FL, USA, 472 pp., 2003.

Bahr, D. B., Meier, M. F., and Peckham, S. D.: The physical basis of glacier volume-area scaling, J. Geophys. Res., 102, 2035520362, 1997.

Barboux, C., Delaloye, R., and Lambiel, C.: Inventorying slope movements in an Alpine environment using DInSAR, Earth Surf. Proc. Land., 39, 2087-2099, 2014.

Barboux, C., Strozzi, T., Delaloye, R., Wegmüller, U., and Collet, C.: Mapping slope movements in Alpine environments using TerraSAR-X interferometric methods, ISPRS J. Photogramm., 109, 178-192, 2015.

Barnhart, T. B., Molotch, N. P., Livneh, B., Harpold, A. A., Knowles, J. F., and Scheneider, D.: Snowmelt rates dictates streamflow, Geophys. Res. Lett., 43, 8006-8016, https://doi.org/10.1002/2016GL069690, 2016.

Bartelt, P., Bühler, Y., Buser, O., Christen, M., and Meier, L.: Modeling mass-dependent flow regime transitions to predict the stopping and depositional behavior of snow avalanches, J. Geophys. Res., 117, F01015, https://doi.org/10.1029/2010JF001957, 2012.

Bavay, M., Grünewald, T., and Lehning, M.: Response of snow cover and runoff to climate change in high Alpine catchments of Eastern Switzerland, Adv. Water Resour., 55, 4-16, https://doi.org/10.1016/j.advwatres.2012.12.009, 2013.

Bebi, P., Kulakowski, D., and Rixen, C.: Snow avalanche disturbances in forest ecosystems - state of research and implications for management, Forest Ecol. Manag., 257, 1883-1892, 2009.

Bednorz, E.: Synoptic conditions of the occurrence of snow cover in central European lowlands, Int. J. Climatol., 31, 1108-1118, https://doi.org/10.1002/joc.2130, 2011.

Beniston, M.: Climate change in mountain regions: a review of possible impacts, Climatic Change, 59, 5-31, 2003.

Beniston, M.: Impacts of climatic change on water and associated economic activities in the Swiss Alps, J. Hydrol., 412-413, 291296, https://doi.org/10.1016/j.jhydrol.2010.06.046, 2012.

Beniston, M. and Stoffel, M.: Rain-on-snow events, floods and climate change in the Alps: events may increase for warming up to $4{ }^{\circ} \mathrm{C}$ and decrease thereafter, Sci. Total Environ., 571, 228-236, https://doi.org/10.1016/j.scitotenv.2016.07.146, 2016.

Beniston, M., Stoffel, M., and Hill, M.: Impacts of climatic change on water and natural hazards in the Alps: Can current water governance cope with future challenges? Examples from the European "ACQWA" project, Environ. Sci. Policy, 14, 734-743, 2011a.

Beniston, M., Uhlmann, B., Goyette, S., and Lopez-Moreno, J. I.: Will snow-abundant winters still exist in the Swiss Alps in an enhanced greenhouse climate?, Int. J. Climatol., 31, 1257-1263, https://doi.org/10.1002/joc.2151, 2011b.

Beniston, M., Stoffel, M., Harding, R., Kernan, M., Ludwig, R., Moors, E., Samuels, P., and Tockner, K.: Obstacles to data access 
for research related to climate and water: implications for science and EU policy-making, Environ. Sci. Policy, 17, 41-48, 2012.

Beniston, M., Stoffel, M., Hill-Clarvis, M., and Allan, A. (Eds.): Mountain water governance: policy implications from the EU "ACQWA" Project, Environ. Sci. Policy, 43, 1-110, 2014.

Berthier, E. and Vincent, C.: Relative contribution of surface mass balance and ice-flux changes to the accelerated thinning of Mer de Glace, French Alps, over 1979-2008, J. Glaciol., 58, 501-512, https://doi.org/10.3189/2012JoG11J083, 2012.

Birsan, M. V. and Dumitrescu, A.: Snow variability in Romania in connection to large-scale atmospheric circulation, Int. J. Climatol., 34, 134-144, https://doi.org/10.1002/joc.3671, 2014.

Biskaborn, B. K., Lanckman, J.-P., Lantuit, H., Elger, K., Streletskiy, D. A., Cable, W. L., and Romanovsky, V. E.: The new database of the Global Terrestrial Network for Permafrost (GTN-P), Earth Syst. Sci. Data, 7, 245-259, https://doi.org/10.5194/essd-7-245-2015, 2015.

Blanchet, J. and Davison, A. C.: Spatial modelling of extreme snow depth, Ann. Appl. Stat., 5, 1699-1725, 2010.

Blanchet, J., Marty, C., and Lehning, M.: Extreme value statistics of snowfall in the Swiss Alpine region, Water Resour. Res., 45, 1-12, https://doi.org/10.1029/2009WR007916, 2009.

Blaschke, A. P., Merz, R., Parajka, J., Salinas, J., and Blöschl, G.: Auswirkungen des Klimawandels auf das Wasserdargebot von Grund- und Oberflächenwasser, Österreichische Wasserund Abfallwirtschaft, 63, 31-41, https://doi.org/10.1007/s00506010-0273-3, 2011.

Blöschl, G., Nester, T., Komma, J., Parajka, J., and Perdigão, R. A. P.: The June 2013 flood in the Upper Danube Basin, and comparisons with the 2002, 1954 and 1899 floods, Hydrol. Earth Syst. Sci., 17, 5197-5212, https://doi.org/10.5194/hess-17-5197-2013, 2013.

Bocchiola, D. and Diolaiuti, G.: Evidence of climate change within the Adamello Glacier of Italy, Theor. Appl. Climatol., 100, 351369, https://doi.org/10.1007/s00704-009-0186-x, 2010.

Boeckli, L., Brenning, A., Gruber, S., and Noetzli, J.: A statistical approach to modelling permafrost distribution in the European Alps or similar mountain ranges, The Cryosphere, 6, 125-140, https://doi.org/10.5194/tc-6-125-2012, 2012.

Bokhorst, S., Pedersen, S. H., Brucker, L., Anisimov, O., Bjerke, J. W., Brown, R. D., Ehrich, D., Essery, R. L. H., Heilig, A., Ingvander, S., Johansson, C., Johansson, M., Svala Jónsdóttir, I., Inga, N., Luojus, K., Macelloni, G., Mariash, H., McLennan, D., Ninis Rosqvist, G., Sato, A., Savela, H., Schneebeli, M., Sokolov, A., Sokratov, S. A., Terzago, S., VikhamarSchuler, D., Williamson, S., Qiu, Y., and Callaghan, T., V.: Changing Arctic snow cover: a review of recent developments and assessment of future needs for observations, modelling, and impacts, Ambio, 45, 516-537, 2016.

Bollschweiler, M. and Stoffel, M.: Changes and trends in debrisflow frequency since AD 1850: Results from the Swiss Alps, Holocene, 20, 907-916, 2010a.

Bollschweiler, M. and Stoffel, M.: Tree rings and debris flows: recent developments, future directions, Prog. Phys. Geog., 34, 625-645, 2010b.

Bommer, C., Phillips, M., and Arenson, L.: Practical recommendations for planning, constructing and maintaining infrastructure in mountain permafrost. Short Communication, Permafrost Periglac., 21, 97-104, https://doi.org/10.1002/ppp.679, 2010.
Borga, M., Stoffel, M., Marchi, L., Marra, F., and Jakob, M.: Hydrogeomorphic response to extreme rainfall in headwater systems: flash floods and debris flows, J. Hydrol., 518, 194-205, 2014.

Boyle, J. and Klein, S. A.: Impact of horizontal resolution on climate model forecasts of tropical precipitation and diabatic heating for the TWP-ICE period, J. Geophys. Res., 115, 1-20, 2010.

Braithwaite, R. J. and Olesen, O. B.: Calculation of glacier ablation from air temperature, West Greenland, in: Glacier Fluctuations and Climatic Change, Springer, Dordrecht, Netherlands, 219-233, 1989.

Braithwaite, R. J. and Zhang, Y.: Modelling changes in glacier mass balance that may occur as a result of climate changes, Geogr. Ann. A, 81, 489-496, 1999.

Brenning, A.: Geomorphological, hydrological and climatic significance of rock glaciers in the Andes of Central Chile (33-35 $\mathrm{S}$ ), Permafrost Periglac., 16, 231-240, 2005.

Brock, B. W., Willis, I. C., and Sharp, M. J.: Measurement and parameterization of albedo variations at Haut Glacier d'Arolla, Switzerland, J. Glaciol., 46, 675-688, 2000.

Brown, I. and Hansson, E.: Contribution to GLIMS Glacier Database, National Snow and Ice Data Center, Boulder, CO, 2004.

Brown, R. D. and Petkova, N.: Snow cover variability in Bulgarian mountainous regions, 1931-2000, Int. J. Climatol., 27, 12151229, https://doi.org/10.1002/joc.1468, 2007.

Brunetti, M., Lentini, G., Maugeri, M., Nanni, T., Auer, I., Böhm, R., and Schöner, W. : Climate variability and change in the Greater Alpine Region over the last two centuries based on multi-variable analysis, Int. J. Climatol., 29, 2197-225, https://doi.org/10.1002/joc.1857, 2009.

Buisan, S. T., Saz, M. A., and López-Moreno, J. I.: Spatial and temporal variability of winter snow and precipitation days in the western and central Spanish Pyrenees, Int. J. Climatol., 35, 259274, https://doi.org/10.1002/joc.3978, 2015.

Calanca, P.: Climate change and drought occurrence in the Alpine region: How severe are becoming the extremes?, Global Planet. Change, 57, 151-160, https://doi.org/10.1016/j.gloplacha.2006.11.001, 2007.

Cappé, O., Moulines, E., and Rydèn, T.: Inference in Hidden Markov Models, Springer, New York, USA, 678 pp., 2005.

Carturan, L., Baroni, C., Brunetti, M., Carton, A., Dalla Fontana, G., Salvatore, M. C., Zanoner, T., and Zuecco, G.: Analysis of the mass balance time series of glaciers in the Italian Alps, The Cryosphere, 10, 695-712, https://doi.org/10.5194/tc-10695-2016, 2016.

Castebrunet, H., Eckert, N., and Giraud, G.: Snow and weather climatic control on snow avalanche occurrence fluctuations over $50 \mathrm{yr}$ in the French Alps, Clim. Past, 8, 855-875, https://doi.org/10.5194/cp-8-855-2012, 2012.

Castebrunet, H., Eckert, N., Giraud, G., Durand, Y., and Morin, S.: Projected changes of snow conditions and avalanche activity in a warming climate: the French Alps over the 2020 2050 and 2070-2100 periods, The Cryosphere, 8, 1673-1697, https://doi.org/10.5194/tc-8-1673-2014, 2014.

Chadburn, S., Burke, E., Essery, R., Boike, J., Langer, M., Heikenfeld, M., Cox, P., and Friedlingstein, P.: An improved representation of physical permafrost dynamics in the JULES land-surface model, Geosci. Model Dev., 8, 1493-1508, https://doi.org/10.5194/gmd-8-1493-2015, 2015. 
Chen, C.-T. and Knutson, T.: On the verification and comparison of extreme rainfall indices from climate models, J. Climate, 21, 1605-1621, 2008.

Choi, G., Robinson, D. A., and Kang, S.: Changing Northern Hemisphere snow seasons, J. Climate, 23, 5305-5310, https://doi.org/10.1175/2010JCLI3644.1, 2010.

Christensen, J. H. and Christensen, O. B.: A summary of the PRUDENCE model projections of changes in European climate by the end of this century, Climatic Change, 81, 7-30, 2007.

Clarke, G. K., Jarosch, A. H., Anslow, F. S., Radić, V., and Menounos, B.: Projected deglaciation of western Canada in the twenty-first century, Nat. Geosci., 8, 372-377, 2015.

Collins, D. N.: Climatic warming, glacier recession and runoff from Alpine basins after the Little Ice Age maximum, Ann. Glaciol., 48, 119-124, 2008.

Corona, C., Lopez Saez, J., Stoffel, M., Bonnefoy, M., Richard, D., Astrade, L., and Berger, F.: How much of the real avalanche activity can be captured with tree rings? An evaluation of classic dendrogeomorphic approaches and comparison with historical archives, Cold Reg. Sci. Technol., 74-75, 31-42, 2012.

Corona, C., Lopez Saez, J., Stoffel, M., Rovéra, G., Edouard, J.-L., and Berger, F.: Seven centuries of avalanche activity at Echalp (Queyras massif, southern French Alps) as inferred from tree rings, Holocene, 23, 292-304, 2013.

Cressie, N. and Wikle, C. K.: Statistics for Spatio-Temporal Data, John Wiley \& Sons, Hoboken, USA, 624 pp., 2011.

Delaloye, R., Perruchoud, E., Avian, M., Kaufmann, V., Bodin, X., Hausmann, H., Ikeda, A., and Kääb, A., Kellerer-Pirkelbauer, A., Krainer, K., Lambiel, C., Mihajlovic, D., Staub, B., Roer, I., and Thibert, E.: Recent interannual variations of rock glacier creep in the European Alps, 9th International Conference on Permafrost, 28 June-3 July, 2008, Fairbanks, Alaska, 1, 343-348, 2008.

Deluigi, N., Lambiel, C., and Kanevski, M.: Data-driven mapping of the potential mountain permafrost distribution, Sci. Total Environ., 590-591, 370-380, https://doi.org/10.1016/j.scitotenv.2017.02.041, 2017.

Diggle, P. and Ribeiro, P. J.: Model-Based Geostatistics, Springer, New York, 232 pp., 2007.

Doetsch, J., Ingeman-Nielsen, T., Christiansen, A. V., Fiandaca, G., Auken, E., and Elberling, B.: Direct current (DC) resistivity and induced polarization (IP) monitoring of active layer dynamics at high temporal resolution, Cold Reg. Sci. Technol., 119, 16-28, 2015

Draebing, D., Haberkorn, A., Krautblatter, M., Kenner, R., and Phillips, M.: Thermal and mechanical responses resulting from spatial and temporal snow cover variability in permafrost rock slopes, Steintaelli, Swiss Alps, Permafrost Periglac., 28, 140157, https://doi.org/10.1002/ppp.1921, 2017.

Durand, Y., Giraud, G., Laternser, M., Etchevers, P., Mérindol, L., and Lesaffre, B.: Reanalysis of 47 years of climate in the French Alps (1958-2005): climatology and trends for snow cover, J. Appl. Meteorol. Clim., 48, 2487-2512, https://doi.org/10.1175/2009JAMC1810.1, 2009.

Dutra, E., Balsamo, G., Viterbo, P., Miranda, P. M., Beljaars, A., Schär, C., and Elder, K.: An improved snow scheme for the ECMWF land surface model: description and offline validation, J. Hydrometeorol., 11, 899-916, 2010.

Dyrrdal, A. V., Saloranta, T., Skaugen, T., and Stranden, H. B.: Changes in snow depth in Norway during the period 1961-2010,
Hydrol. Res., 44, 169, https://doi.org/10.2166/nh.2012.064, 2013.

Eckert, N., Baya, H., and Deschatres, M.: Assessing the response of snow avalanche runout elevations to climate fluctuations using hierarchical modeling: application to 61 winters of data in France, J. Climate, 23, 3157-3180, https://doi.org/10.1175/2010JCLI3312.1, 2010.

Eckert, N., Keylock, C. J., Castebrunet, H., Lavigne, A., and Naaim, M.: Temporal trends in avalanche activity in the French Alps and subregions: from occurrences and runout elevations to unsteady return periods, J. Glaciol., 59, 93-114, https://doi.org/10.3189/2013JoG12J091, 2013.

EEA: Impacts of Europe's changing climate. An indicator-based assessment, Report 2/2004, European Environmental Agency, Copenhagen, Denmark, 2004.

EEA: Regional climate change and adaptation. The Alps faciing the challenge of changing water resources, Technical report, 9/2009, European Environmental Agency, Copenhagen, Denmark, 2009.

Ekici, A., Chadburn, S., Chaudhary, N., Hajdu, L. H., Marmy, A., Peng, S., Boike, J., Burke, E., Friend, A. D., Hauck, C., Krinner, G., Langer, M., Miller, P. A., and Beer, C.: Site-level model intercomparison of high latitude and high altitude soil thermal dynamics in tundra and barren landscapes, The Cryosphere, 9, 1343-1361, https://doi.org/10.5194/tc-9-1343-2015, 2015.

Endrizzi, S., Gruber, S., Dall'Amico, M., and Rigon, R.: GEOtop 2.0: simulating the combined energy and water balance at and below the land surface accounting for soil freezing, snow cover and terrain effects, Geosci. Model Dev., 7, 2831-2857, https://doi.org/10.5194/gmd-7-2831-2014, 2014.

Engelhardt, M., Schuler, T. V., and Andreassen, L. M.: Sensitivities of glacier mass balance and runoff to climate perturbations in Norway, Ann. Glaciol., 56, 7988,https://doi.org/10.3189/2015AoG70A004, 2015.

Essery, R.: A factorial snowpack model (FSM 1.0), Geosci. Model Dev., 8, 3867-3876, https://doi.org/10.5194/gmd-8-3867-2015, 2015.

Etzelmüller, B.: Recent advances in mountain permafrost research, Permafrost Periglac., 24, 99-107, 2013.

Faillettaz, J., Funk, M., and Vincent, C.: Avalanching glacier instabilities: review on processes and early warning perspectives, Rev. Geophys., 53, 203-224, https://doi.org/10.1002/2014RG000466, 2015.

Falarz, M.: Changes in extreme nival conditions in Poland during the second half of the 20th century, Meteorol. Z., 17, 339-344, https://doi.org/10.1127/0941-2948/2008/0293, 2008.

Farbrot, H., Isaksen, K., Etzelmüller, B., and Gisnås, K.: Ground thermal regime and permafrost distribution under a changing climate in northern Norway, Permafrost Periglac., 24, 20-38, 2013.

Farinotti, D., Usselmann, S., Huss, M., Bauder, A., and Funk, M.: Runoff evolution in the Swiss Alps: projections for selected high-alpine catchments based on ENSEMBLES scenarios, Hydrol. Process., 26, 1909-1924, https://doi.org/10.1002/hyp.8276, 2012.

Farinotti, D., Pistocchi, A., and Huss, M.: From dwindling ice to headwater lakes: could dams replace glaciers in the European Alps?, Environ. Res. Lett., 11, 054022, https://doi.org/10.1088/1748-9326/11/5/054022, 2016.

Farinotti, D., Brinkerhoff, D. J., Clarke, G. K. C., Fürst, J. J., Frey, H., Gantayat, P., Gillet-Chaulet, F., Girard, C., Huss, M., 
Leclercq, P. W., Linsbauer, A., Machguth, H., Martin, C., Maussion, F., Morlighem, M., Mosbeux, C., Pandit, A., Portmann, A., Rabatel, A., Ramsankaran, R., Reerink, T. J., Sanchez, O., Stentoft, P. A., Singh Kumari, S., van Pelt, W. J. J., Anderson, B., Benham, T., Binder, D., Dowdeswell, J. A., Fischer, A., Helfricht, K., Kutuzov, S., Lavrentiev, I., McNabb, R., Gudmundsson, G. H., Li, H., and Andreassen, L. M.: How accurate are estimates of glacier ice thickness? Results from ITMIX, the Ice Thickness Models Intercomparison eXperiment, The Cryosphere, 11, 949-970, https://doi.org/10.5194/tc11-949-2017, 2017.

Favier, P., Bertrand, D., Eckert, N., and Naaim, M.: A reliability assessment of physical vulnerability of reinforced concrete walls loaded by snow avalanches, Nat. Hazards Earth Syst. Sci., 14, 689-704, https://doi.org/10.5194/nhess-14-689-2014, 2014.

Fiddes, J., Endrizzi, S., and Gruber, S.: Large-area land surface simulations in heterogeneous terrain driven by global data sets: application to mountain permafrost, The Cryosphere, 9, 411-426, https://doi.org/10.5194/tc-9-411-2015, 2015.

Fischer, L., Purves, R. S., Huggel, C., Noetzli, J., and Haeberli, W.: On the influence of topographic, geological and cryospheric factors on rock avalanches and rockfalls in highmountain areas, Nat. Hazards Earth Syst. Sci., 12, 241-254, https://doi.org/10.5194/nhess-12-241-2012, 2012.

Fischer, M, Huss, M., Barboux, C., and Hoelzle, M.: The new Swiss Glacier Inventory SGI2010: relevance of using high-resolution source data in areas dominated by very small glaciers, Arct. Antarct. Alp. Res., 46, 933-945, 2014.

FOEN: Effect of Climate Change on Water Resources and Waters, Synthesis report on "Climate Change and Hydrology in Switzerland" (CCHydro project), Federal Office of the Environment, Bern, 2012.

Frey, H., Haeberli, W., Linsbauer, A., Huggel, C., and Paul, F.: A multi-level strategy for anticipating future glacier lake formation and associated hazard potentials, Nat. Hazards Earth Syst. Sci., 10, 339-352, https://doi.org/10.5194/nhess-10-3392010, 2010.

Fuhrer, J., Beniston, M., Fischlin, A., Frei, C. H., Goyette, S., Jasper, K., and Pfister, C. H.: Climate risks and their impact on agriculture and forests in Switzerland, Climatic Change, 79, 79$102,2006$.

Gabbi, J., Carenzo, M., Pellicciotti, F., Bauder, A., and Funk, M.: A comparison of empirical and physically based glacier surface melt models for long-term simulations of glacier response, J. Glaciol., 60, 1140-1154, https://doi.org/10.3189/2014JoG14J011, 2014.

Gabbi, J., Huss, M., Bauder, A., Cao, F., and Schwikowski, M.: The impact of Saharan dust and black carbon on albedo and long-term mass balance of an Alpine glacier, The Cryosphere, 9, 13851400, https://doi.org/10.5194/tc-9-1385-2015, 2015.

Gajić-Čapka, M.: Snow climate baseline conditions and trends in Croatia relevant to winter tourism, Theor. Appl. Climatol., 105, 181-191, https://doi.org/10.1007/s00704-010-0385-5, 2011.

Gao, T., Zhang, T., Cao, L., Kang, S., and Sillanpää, M.: Reduced winter runoff in a mountainous permafrost region in the northern Tibetan Plateau, Cold Reg. Sci. Technol., 126, 36-43, 2016.

Gardent, M., Rabatel, A., Dedieu, J. P., and Deline, P.: Multitemporal glacier inventory of the French Alps from the late 1960s to the late 2000s, Global Planet. Change, 120, 24-37, https://doi.org/10.1016/j.gloplacha.2014.05.004, 2014.

Gaudard, L. and Romerio, F.: The future of hydropower in Europe: interconnecting climate, markets and policies, Environ. Sci. Policy, 37, 172-181, 2014.

Gaudard, L., Romerio, F., Dalla Valle, F., Gorret, R., Maran, S., Ravazzani, G., Stoffel, M., and Volonterio, M.: Climate change impacts on hydropower in the Swiss and Italian Alps, Sci. Total Environ., 493, 1211-1221, 2014.

Gaume, J., Eckert, N., Chambon, G., Eckert, N., Naaim, M., and Bel, L.: Mapping extreme snowfalls in the French Alps using Max-Stable processes, Water Resour. Res., 49, 1079-1098, 2013.

Genton, M. and Kleiber, W.: Cross-covariance functions for multivariate geostatistics, Stat. Sci., 30, 147-163, 2015.

Gerbaux, M., Genthon, C., Etchevers, P., Vincent, C., and Dedieu, J. P.: Surface mass balance of glaciers in the French Alps: distributed modeling and sensitivity to climate change, J. Glaciol., 51, 561-572, 2005.

GFS documentation: The Global Forecast System (GFS) - Global Spectral Model (GSM Version 13.0.2), Global Climate \& Weather Modeling Branch, available at: http://www.emc.ncep. noaa.gov/GFS/doc.php (last access: May 2016), 2016.

Giesen, R. H. and Oerlemans, J.: Response of the ice cap Hardangerjøkulen in southern Norway to the 20th and 21st century climates, The Cryosphere, 4, 191-213, https://doi.org/10.5194/tc4-191-2010, 2010.

Gilaberte, M., Pino, M. R., López, F., and López-Moreno, J. I.: Impacts of climate change on ski industry, Environ. Sci. Policy, 44, 51-61, 2014.

Gilbert, A., Vincent, C., Wagnon, P., Thibert, E., and Rabatel, A.: The influence of snow cover thickness on the thermal regime of Tête Rousse Glacier (Mont Blanc range, $3200 \mathrm{~m}$ a.s.1.): consequences for outburst flood hazards and glacier response to climate change, J. Geophys. Res., 117, F04018, https://doi.org/10.1029/2011JF002258, 2012.

Gilbert, A., Vincent, C., Six, D., Wagnon, P., Piard, L., and Ginot, P.: Modeling near-surface firn temperature in a cold accumulation zone (Col du Dôme, French Alps): from a physical to a semi-parameterized approach, The Cryosphere, 8, 689-703, https://doi.org/10.5194/tc-8-689-2014, 2014.

Gilks, W. R., Richardson, S., and Spiegelhalter, D. J.: Markov Chain Monte Carlo in Practice, Chapman \& Hall, New York, USA, 486 pp., 2001.

Gisnås, K., Westermann, S., Schuler, T. V., Litherland, T., Isaksen, K., Boike, J., and Etzelmüller, B.: A statistical approach to represent small-scale variability of permafrost temperatures due to snow cover, The Cryosphere, 8, 2063-2074, https://doi.org/10.5194/tc-8-2063-2014, 2014.

Gisnås, K., Etzelmüller, B., Lussana, C., Hjort, J., Sannel, A. B. K., Isaksen, K., Westermann, S., Kuhry, P., Christiansen, H. H., Frampton, A., and Åkerman, J.: Permafrost map for Norway, Sweden and Finland, Permafrost Periglac., 28, 359-378, https://doi.org/10.1002/ppp.1922, 2016.

Gisnås, K., Etzelmüller, B., Lussana, C., Hjort, J., Sannel, A. B. K., Isaksen, K., Westermann, S., Kuhry, P., Christiansen, H. H., Frampton, A., and Åkerman, J.: Permafrost map for Norway, Sweden and Finland, Permafrost Periglac., 28, 359-378, 2017.

Gneiting, T., Genton, M. G., and Guttorp, P.: Geostatistical spacetime models, stationarity, separability and full symmetry, in: 
Statistical Methods for Spatio-Temporal Systems, edited by: Finkenstadt, B., Held, L., and Isham, V., Chapman \& Hall/CRC, Boca Raton, 151-175, 2007.

Gobiet, A., Kotlarski, S., Beniston, M., Heinrich, G., Rajczak, J., and Stoffel, M.: 21st century climate change in the European Alps - a review, Sci. Total Environ., 493, 1138-1151, https://doi.org/10.1016/j.scitotenv.2013.07.050, 2014.

Gornall, J., Betts, R., Burke, E., Clark, R., Camp, J., Willett, K., and Wiltshire, A.: Implications of climate change for agricultural productivity in the early twenty-first century, Philos. T. R. Soc. B, 365, 2973-2989, 2010.

Gruber, S.: Derivation and analysis of a high-resolution estimate of global permafrost zonation, The Cryosphere, 6, 221-233, https://doi.org/10.5194/tc-6-221-2012, 2012.

Gruber, S. and Haeberli, W.: Mountain permafrost, in: Permafrost Soils, edited by: Margesin, R., Springer, Berlin, Germany, 33-44, 2009.

Grünewald, T., Schirmer, M., Mott, R., and Lehning, M.: Spatial and temporal variability of snow depth and ablation rates in a small mountain catchment, The Cryosphere, 4, 215-225, https://doi.org/10.5194/tc-4-215-2010, 2010.

Grünewald, T., Bühler, Y., and Lehning, M.: Elevation dependency of mountain snow depth, The Cryosphere, 8, 2381-2394, https://doi.org/10.5194/tc-8-2381-2014, 2014.

Gubler, S., Fiddes, J., Keller, M., and Gruber, S.: Scaledependent measurement and analysis of ground surface temperature variability in alpine terrain, The Cryosphere, 5, 431-443, https://doi.org/10.5194/tc-5-431-2011, 2011.

Gubler, S., Endrizzi, S., Gruber, S., and Purves, R. S.: Sensitivities and uncertainties of modeled ground temperatures in mountain environments, Geosci. Model Dev., 6, 1319-1336, https://doi.org/10.5194/gmd-6-1319-2013, 2013.

Haberkorn, A., Wever, N., Hoelzle, M., Phillips, M., Kenner, R., Bavay, M., and Lehning, M.: Distributed snow and rock temperature modelling in steep rock walls using Alpine3D, The Cryosphere, 11, 585-607, https://doi.org/10.5194/tc-11585-2017, 2017.

Haeberli, W: Climate change and high-mountain regions - adaptation strategies for the Alps, in: Meeting of Minds: DecisionMakers from Asian and Alpine Mountain Countries Sharing Policy Experiences in Regional Cooperation for Sustainable Mountain Development, edited by: Kreutzmann, H., Hofer, T., and Richter, J., German Federal Ministry for Economic Cooperation and Development, Bonn, Germany, 59-66, 2009.

Haeberli, W.: Mountain permafrost - research frontiers and a special long-term challenge, Cold Reg. Sci. Technol., 96, 71-76, 2013.

Haeberli, W. and Beniston, M.: Climate change and its impacts on glaciers and permafrost in the Alps, Ambio, 258-265, 1998.

Haeberli, W. and Linsbauer, A.: Brief communication "Global glacier volumes and sea level - small but systematic effects of ice below the surface of the ocean and of new local lakes on land", The Cryosphere, 7, 817-821, https://doi.org/10.5194/tc-7817-2013, 2013.

Haeberli, W., Hoelzle, M., Kääb, A., Keller, F., Vonder Mühll, D., and Wagner, S.: Ten years after drilling through the permafrost of the active rock glacier Murtèl, eastern Swiss Alps: answered questions and new perspectives, in: Collection Nordicana, 7th International Conference on Permafrost, 23-27 June 1998, edited by: Lewkowicz, A. G., and Allard, M., Université Laval, Yellowknife, Canada, 403-410, 1998.

Haeberli, W., Kääb, A., Paul, F., Chiarle, M., Mortara, G., Mazza, A., Deline, P., and Richardson, S.: A surge-type movement at Ghiacciaio del Belvedere and a developing slope instability in the east face of Monte Rosa, Macugnaga, Italian Alps, Norsk Geogr. Tidsskr., 56, 104-111, 2002.

Haeberli, W., Clague, J. J., Huggel, C., and Kääb, A.: Hazards from lakes in high-mountain glacier and permafrost regions: climate change effects and process interactions. Avances de la Geomorphologí a España, 2008-2010, XI Reunión Nacional de Geomorphología, Solsonna, 439-446, 2010.

Haeberli, W., Bütler, M., Huggel, C., Lehmann, T., Schaub, Y., and Schleiss, A.: New lakes in deglaciating high-mountain regions opportunities and risks, Climatic Change, 139, 201-214, 2016.

Haeberli, W., Schaub, Y., and Huggel, C. Increasing risks related to landslides from degrading permafrost into new lakes in de-glaciating mountain ranges, Geomorphology, 293, 405-417, https://doi.org/10.1016/j.geomorph.2016.02.009, 2017.

Hanzer, F., Helfricht, K., Marke, T., and Strasser, U.: Multilevel spatiotemporal validation of snow/ice mass balance and runoff modeling in glacierized catchments, The Cryosphere, 10, 1859-1881, https://doi.org/10.5194/tc-10-1859-2016, 2016.

Hanzer, F., Förster, K., Nemec, J., and Strasser, U.: Projected cryospheric and hydrological impacts of 21 st century climate change in the Ötztal Alps (Austria) simulated using a physically based approach, Hydrol. Earth Syst. Sci. Discuss., https://doi.org/10.5194/hess-2017-309, in press, 2017.

Harris, C., Arensonb, L. U., Christiansen, H. H., Etzelmüllerd, B., Frauenfelder, R., Gruber, S., Haeberli, W., Hauck, C., Hölzle, M., Humlum, O., Isaksen, K., Kääb, A., Kern-Lütschg, M. A., Lehning, M., Matsuoka, N., Murton, J. B., Nötzli, J., Phillips, M., Ross, N., Seppälä, M., Springman, S. M., and Vonder Mühlln, D.: Permafrost and climate in Europe: monitoring and modelling thermal, geomorphological and geotechnical responses, EarthSci. Rev., 92, 117-171, 2009.

Harrison, G. P. and Whittington, H. W.: Impact of climatic change on hydropower investment, in: Proceedings of the Fourth International Conference on Hydropower Development Hydropower, Hydropower in the New Millennium, Bergen, Norway, 20-22 June 2001, 257-261, 2001.

Hartl, L., Fischer, A., Stocker-Waldhuber, M., and Abermann, J.: Recent speed-up of an alpine rock glacier: an updated chronology of the kinematics of outer hochebenkar rock glacier based on geodetic measurements, Geogr. Ann. A, 98, 129-141, 2016.

Hasler, A., Gruber, S., and Beutel, J.: Kinematics of steep bedrock permafrost, J. Geophys. Res., 117, F01016, https://doi.org/10.1029/2011JF001981, 2012.

Hauck, C.: New concepts in geophysical surveying and data interpretation for permafrost terrain, Permafrost Periglac., 24, 131137, https://doi.org/10.1002/ppp.1774, 2013.

Hauenstein, W.: Hydropower and climate change - a reciprocal relation: institutional energy issues in Switzerland, Mt. Res. Dev., 25, 321-325, 2005.

Heinrich, G., Gobiet, A., and Mendlik, T.: Extended regional climate model projections for Europe until the mid-twentyfirst century: combining ENSEMBLES and CMIP3. Clim. Dynam., 42, 521-535, 2014. 
Henderson, G. R. and Leathers, D. J.: European snow cover extent variability and associations with atmospheric forcings, Int. J. Climatol., 30, 1440-1451, https://doi.org/10.1002/joc.1990, 2010.

Hilbich, C., Hauck, C., Hoelzle, M., Scherler, M., Schudel, L., Völksch, I., Vonder Mühll, D., and Mäusbacher, R.: Monitoring mountain permafrost evolution using electrical resistivity tomography: a 7-year study of seasonal, annual, and long-term variations at Schilthorn, Swiss Alps, J. Geophys. Res., 113, F01S90, https://doi.org/10.1029/2007JF000799, 2008a.

Hilbich, C., Hauck, C., Delaloye, R., and Hoelzle, M.: A geoelectric monitoring network and resistivity-temperature relationships of different mountain permafrost sites in the Swiss Alps, in: Proceedings of the Ninth International Conference on Permafrost, Fairbanks, 28 June-3 July 2008, 1, edited by: Kane, D. L., and Hinkel, K. M., Institute of Northern Engineering, University of Alaska, Fairbanks, 699-704, 2008b.

Hilbich, C., Fuss, C., and Hauck, C.: Automated time-lapse ERT for improved process analysis and monitoring of frozen ground, Permafrost Periglac., 22, 306-319, https://doi.org/10.1002/ppp.732, 2011

Hill Clarvis, M., Fatichi, S., Allan, A. A., Fuhrer, J., Stoffel, M., Romerio, F., Gaudard, L., Burlando, P., Beniston, M., Xoplaki, E., and Toreti, A.: Governing and managing water resources under changing hydro-climatic contexts: The case of the Upper Rhone Basin, Environ. Sci. Pol., 43, 56-67, https://doi.org/10.1016/j.envsci.2013.11.005, 2014.

Hipp, T., Etzelmüller, B., Farbrot, H., Schuler, T. V., and Westermann, S.: Modelling borehole temperatures in Southern Norway - insights into permafrost dynamics during the 20th and $21 \mathrm{st}$ century, The Cryosphere, 6, 553-571, https://doi.org/10.5194/tc6-553-2012, 2012.

Hock, R.: A distributed temperature-index ice- and snowmelt model including potential direct solar radiation, J. Glaciol., 45, 101$111,1999$.

Hoelzle, M., Darms, G., Lüthi, M. P., and Suter, S.: Evidence of accelerated englacial warming in the Monte Rosa area, Switzerland/Italy, The Cryoshere, 5, 231-243, https://doi.org/10.5194/tc-5-231-2011, 2011.

Horton, P., Schaefli, B., Mezghani, A., Hingray, B., and Musy, A.: Assessment of climate-change impacts on alpine discharge regimes with climate model uncertainty, Hydrol. Process., 20, 2091-2109, 2006.

Hu, J., Moore, D. J. P., Burns, S. P., and Monson, R.: Longer growing seasons lead to less carbon sequestration by a subalpine forest, Glob. Change Biol., 16, 771-783, https://doi.org/10.1111/j.1365-2486.2009.01967.x, 2010.

Huggel, C., Allen, S., Deline, P., Fischer, L., Noetzli, J., and Ravanel, L.: Ice thawing, mountains falling - are alpine rock slope failures increasing?, Geology Today, 28, 102-108, 2012.

Huggel, C., Allen, S., Clague, J. J., Fischer, L., Korup, O., and Schneider, D.: Detecting potential climate signals in large slope failures in cold mountain regions, in: Landslide Science and Practice, edited by: Margottini, C., Canuti, P., and Sassa, K., Springer, Berlin Heidelberg, Germany, 361-367, 2013.

Hüsler, F., Jonas, T., Riffler, M., Musial, J. P., and Wunderle, S.: A satellite-based snow cover climatology (1985-2011) for the European Alps derived from AVHRR data, The Cryosphere, 8, 73-90, https://doi.org/10.5194/tc-8-73-2014, 2014.
Huss, M.: Present and future contribution of glaciers to runoff from macroscale drainage basins in Europe, Water Resour. Res., 47, W07511, https://doi.org/10.1029/2010WR010299, 2011.

Huss, M.: Extrapolating glacier mass balance to the mountain-range scale: the European Alps 1900-2100, The Cryosphere, 6, 713727, https://doi.org/10.5194/tc-6-713-2012, 2012.

Huss, M. and Farinotti, D.: Distributed ice thickness and volume of all glaciers around the globe, J. Geophys. Res., 117, F04010, https://doi.org/10.1029/2012JF002523, 2012.

Huss, M. and Hock, R.: A new model for global glacier change and sea-level rise, Front. Earth Sci., 3, 34, https://doi.org/10.3389/feart.2015.00054, 2015.

Huss, M., Funk, M., and Ohmura, A.: Strong Alpine glacier melt in the 1940s due to enhanced solar radiation, Geophys. Res. Lett., 36, L23501, https://doi.org/10.1029/2009GL040789, 2009.

Huss, M., Jouvet, G., Farinotti, D., and Bauder, A.: Future high-mountain hydrology: a new parameterization of glacier retreat, Hydrol. Earth Syst. Sci., 14, 815-829, https://doi.org/10.5194/hess-14-815-2010, 2010.

Huss, M., Joerg, P. C., Zemp, M., and Salzmann, N.: High uncertainty in 21 st century runoff projections from glacierized basins, J. Hydrol., 510, 35-48, 2014.

Huss, M., Bookhagen, B., Huggel, C., Jacobsen, D., Bradley, R. S., Clague, J. J., Vuille, M., Buytaert, W., Cayan, D. R., Greenwood, G., Mark, B. G., Milner, A. M., Weingartner, R., and Winder, M.: Toward mountains without permanent snow and ice, Earths Future, 5, 418-435, https://doi.org/10.1002/2016EF000514, 2017.

IFS documentation, CY41r2, Part IV: Physical Processes, Chapter 8, ECMWF, available at: http://www.ecmwf.int/sites/default/ files/elibrary/2016/16648-part-iv-physical-processes.pdf, last access: September 2016.

Ikeda, A., Matsuoka, N., and Kääb, A.: Fast deformation of perennially frozen debris in a warm rock glacier in the Swiss Alps: an effect of liquid water, J. Geophys. Res.-Earth, 113, F01021, https://doi.org/10.1029/2007jf000859, 2008.

Imperio, S., Bionda, R., Viterbi, R., and Provenzale, A.: Climate change and human disturbance can lead to local extinction of Alpine rock ptarmigan: new insight from the western Italian Alps, PLOS One, 8, https://doi.org/10.1371/journal.pone.0081598, 2013.

IPCC: Managing the Risks of Extreme Events and Disasters to Advance Climate Change Adaptation. A Special Report of Working Groups I and II of the Intergovernmental Panel on Climate Change, edited by: Field, C. B., Barros, V., Stocker, T. F., Qin, D., Dokken, D. J., Ebi, K. L., Mastrandrea, M. D., Mach, K. J., Plattner, G.-K., Allen, S. K., Tignor, M., and Midgley, P. M., Cambridge University Press, Cambridge, UK and New York, NY, USA, 582 pp., 2012.

IPCC: Climate change 2013: The Physical Science Basis. Contribution of Working Group I to the Fifth Assessment Report of the Intergovernmental Panel on Climate Change, edited by: Stocker, T. F., Qin, D., Plattner, G.-K., Tignor, M., Allen, S. K., Boschung, J., Nauels, A., Xia, Y., Bex, V., and Midgley, P. M., Cambridge University Press, Cambridge, UK and New York, NY, USA, 1535 pp., 2013.

Isaksen, K., Sollid, J. L., Holmlund, P., and Harris, D.: Recent warming of mountain permafrost temperatures in Svalbard in 
relatioin to future climate scenarios, Geophys. Res. Lett., 34, L17502, https://doi.org/10.1029/2007GL031002, 2007.

Isaksen, K., Ødegård, R. S., Etzelmüller, B., Hilbich, C., Hauck, C., Farbrot, H., Eiken, T., Hygen, H. O., and Hipp, T.: Degrading mountain permafrost in southern Norway: spatial and temporal variability of mean ground temperatures, 1999-2009, Permafrost Periglac., 22, 361-377, 2011.

Jaggard, K. W., Qi, A. M., and Ober, E. S.: Possible changes to arable crop yields by 2050, Philos. T. R. Soc. B, 365, 2835-2851, 2010.

Jansson, P., Hock, R., and Schneider, T.: The concept of glacier storage: a review, J. Hydrol., 282, 116-129, 2003.

Jansson, P. E.: CoupModel: model use, calibration, and validation, T. Asabe., 55, 1335-134, 2012.

Jasper, K., Calanca, P. L., Gyalistras, D., and Fuhrer, J.: Differential impacts of climate change on the hydrology of two alpine river basis, Clim. Res., 26, 113-129, 2004.

Johansson, C., Pohjola, V. A., Jonasson, C., and Callaghan, T. V.: Multi-decadal changes in snow characteristics in sub-arctic Sweden, Ambio, 40, 566, https://doi.org/10.1007/s13280-011-01642, 2011.

Jonas, T., Marty, C., and Magnusson, J.: Estimating the snow water equivalent from snow depth measurements in the Swiss Alps, J. Hydrol., 378, 161-167, 2009.

Jouvet, G., Huss, M., Blatter, H., Picasso, M., and Rappaz, J.: Numerical simulation of Rhonegletscher from 1874 to 2100 , J. Comput. Phys., 228, 6426-6439, 2009.

Jouvet, G., Rappaz, J., Bueler, E., and Blatter, H.: Existence and stability of steady state solutions of the shallow ice sheet equation by an energy minimization approach, J. Glaciol., 57, 345-354, 2011.

Jylhä, K., Fronzek, S., Tuomenvirta, H., Carter, T. R., and Ruosteenoja, K.: Changes in frost, snow and Baltic Sea ice by the end of the twenty-first century based on climate model projections for Europe, Climatic Change, 86, 441-462, https://doi.org/10.1007/s10584-007-9310-z, 2008.

Kääb, A.: Remote sensing of permafrost-related problems and hazards, Permafrost Periglac., 19, 107-136, https://doi.org/10.1002/ppp.619, 2008.

Kang, I. S., Yang, Y. M., and Tao, W. K.: GCMs with implicit and explicit representation of cloud microphysics for simulation of extreme precipitation frequency, Clim. Dynam., 45, 325-335, 2015.

Kaser, G., Großhauser, M., and Marzeion, B.: Contribution potential of glaciers to water availability in different climate regimes, P. Natl. Acad. Sci. USA, 107, 20223-20227, 2010.

Kaufmann, V.: The evolution of rock glacier monitoring using terrestrial photogrammetry: the example of Äusseres Hochebenkar rock glacier (Austria), Austrian J. Earth Sc., 105, 63-77, 2012.

Kenner, R., Bühler, Y., Delaloye, R., Ginzler, C., and Phillips, M.: Monitoring of high alpine mass movements combining laser scanning with digital airborne photogrammetry, Geomorphology, 206, 492-504, 2014.

Kenner, R., Chinellato, G., Iasio, C., Mosna, D., Cuozzo, G., Benedetti, E., Visconti, M. G., Manunta, M., Phillips, M., Mair, V., and Zischg, A.: Integration of space-borne DInSAR data in a multi-method monitoring concept for alpine mass movements, Cold Reg. Sci. Technol., 131, 65-75, 2016.
KHR/CHR: The Snow and Glacier Melt Components of Streamflow of the River Rhine and its Tributaries Considering the Influence of Climate Change, Synthesis Report, Report No. I-25, International Commission for the Hydrology of the Rhine Basin, Freiburg, Germany, ISBN/EAN 978-90-70980-38-2, 2016.

Kirchner, P. B., Bales, R. C., Molotch, N. P., Flanagan, J., and Guo, Q.: LiDAR measurement of seasonal snow accumulation along an elevation gradient in the southern Sierra Nevada, California, Hydrol. Earth Syst. Sci., 18, 4261-4275, https://doi.org/10.5194/hess-18-4261-2014, 2014.

Kivinen, S. and Rasmus, S.: Observed cold season changes in a Fennoscandian fell area over the past three decades, Ambio, 44, 214-225, https://doi.org/10.1007/s13280-014-0541-8, 2015.

Klein, G., Vitasse, Y., Rixen, C., Marty, C., and Rebetez, M.: Shorter snow cover duration since 1970 in the Swiss Alps due to earlier snowmelt more than later snow onset, Climatic Change, 139, 637-649, https://doi.org/10.1007/s10584016-1806-y, 2016.

Klemes, V.: The modelling of mountain hydrology: the ultimate challenge, IAHS-AISH P., 190, 29-43, 1990.

Klug, C., Bollmann, E., Kääb, A., Krainer, K., Sailer, R., and Stötter, J.: Monitoring of permafrost creep on two rock glaciers in the Austrian eastern Alps: combination of aerophotogrammetry and airborne laser scanning, in: Proceedings of the 10th International Conference on Permafrost, 25-29 June 2012, Salekhard, 215-226, 2012.

Kneisel, C., Hauck, C., Fortier, R., and Moorman, B.: Advances in geophysical methods for permafrost investigation, Permafrost Periglac., 19, 157-178, 2008.

Köplin, N., Rößler, O., Schädler, B., and Weingartner, R.: Robust estimates of climate-induced hydrological change in a temperate mountainous region, Climatic Change, 122, 171-184, https://doi.org/10.1007/s10584-013-1015-x, 2014.

Korup, O., Görüm, T., and Hayakawa, Y.: Without power? Landslide inventories in the face of climate change, Earth Surf. Proc. Land., 37, 92-99, 2012.

Kotlarski, S., Keuler, K., Christensen, O. B., Colette, A., Déqué, M., Gobiet, A., Goergen, K., Jacob, D., Lüthi, D., van Meijgaard, E., Nikulin, G., Schär, C., Teichmann, C., Vautard, R., Warrach-Sagi, K., and Wulfmeyer, V.: Regional climate modeling on European scales: a joint standard evaluation of the EUROCORDEX RCM ensemble, Geosci. Model Dev., 7, 1297-1333, https://doi.org/10.5194/gmd-7-1297-2014, 2014.

Krautblatter, M., Huggel, C., Deline, P., and Hasler, A.: Research perspectives on unstable high-alpine bedrock permafrost: measurement, modelling and process understanding, Permafrost Periglac., 23, 80-88, 2012.

Krol, Q. and Lowe, H.: Analysis of local ice crystal growth in snow, J. Glaciol., 62, 378-390, https://doi.org/10.1017/jog.2016.32, 2016.

Kumar, A., Schei, T., Ahenkorah, A., Rodriguez, R. C., Devernay, J.-M., Freitas, M., Hall, D., Killingtveit, A., and Liu, Z.: Hydropower IPCC Special Report on Renewable Energy Sources and Climate Change Mitigation, Cambridge University Press, Cambridge and New York, 2011.

Kumar, M., Marks, D., Dozier, J., Reba, M., and Winstral, A.: Evaluation of distributed hydrologic impacts of temperature-index and energy-based snow models, Adv. Water Resour., 56, 77-89, https://doi.org/10.1016/j.advwatres.2013.03.006, 2013. 
Kunkel, K. E., Robinson, D. A., Champion, S., Yin, X., Estilow, T., and Frankson, R. M.: Trends and extremes in Northern Hemisphere snow characteristics, Current Climate Change Reports, 2 , 65-73, https://doi.org/10.1007/s40641-016-0036-8, 2016.

Lafaysse, M., Hingray, B., Mezghani, A., Gailhard, J., and Terray, L.: Internal variability and modeluncertainty components in future hydrometeorological projections: the Alpine Durance Basin, Water Resour. Res., 50, 3317-3341, https://doi.org/10.1002/2013WR014897, 2014.

Laghari, A. N., Vanham, D., and Rauch, W.: To what extent does climate change result in a shift in Alpine hydrology? A case study in the Austrian Alps, Hydrolog. Sci. J., 57, 103-117, https://doi.org/10.1080/02626667.2011.637040, 2012.

Lane, S. N., Bakker, M., Gabbud, C., Micheletti, N., and Saugy, J. N.: Sediment export, transient landscape response and catchment-scale connectivity following rapid climate warming and Alpine glacier recession, Geomorphology, 277, 210-227, https://doi.org/10.1016/j.geomorph.2016.02.015, 2016.

Laumann, T. and Nesje, A.: A simple method of simulating the future frontal position of Briksdalsbreen, western Norway, Holocene, 19, 221-228, 2009.

Laumann, T. and Nesje, A.: Spørteggbreen, western Norway, in the past, present and future: simulations with a twodimensional dynamical glacier model, Holocene, 24, 842852,10.1177/0959683614530446, 2014.

Lehning, M., Bartelt, P., Brown, B., Russi, T., Stockli, U., and Zimmerli, M.: SNOWPACK model calculations for avalanche warning based upon a new network of weather and snow stations, Cold Reg. Sci. Technol., 30, 145-157, 1999.

Lehning, M., Bartelt, P., Brown, B., Fierz, C., and Satyawali, P.: A physical SNOWPACK model for the Swiss avalanche warning Part II: Snow microstructure, Cold Reg. Sci. Technol., 35, 147167, https://doi.org/10.1016/S0165-232X(02)00073-3, 2002.

Lehning, M., Völksch, I., Gustafsson, D., Nguyen, T. A., Stähli, M., and Zappa, M.: ALPINE3D: a detailed model of mountain surface processes and its application to snow hydrology, Hydrol. Process., 20, 2111-2128, https://doi.org/10.1002/hyp.6204, 2006.

Lehning, M., Lowe, H., Ryser, M., and Raderschall, N.: Inhomogeneous precipitation distribution and snow transport in steep terrain, Water Resour. Res., 44, W07404, https://doi.org/10.1029/2007wr006545, 2008.

Leisenring, M. and Moradkhani, H.: Snow water equivalent prediction using Bayesian data assimilation methods, Stoch. Env. Res. Risk A., 25, 253-270, 2011.

Le Meur, E., Gagliardini, O., Zwinger, T., and Ruokolainen, J.: Glacier flow modelling: a comparison of the Shallow Ice Approximation and the full-Stokes solution, C. R. Phys., 5, 709722,2004

Li, C., Stevens, B., and Marotzke, J.: Eurasian winter cooling in the warming hiatus of 1998-2012, Geophys. Res. Lett., 42, 81318139, https://doi.org/10.1002/2015GL065327, 2015.

Linsbauer, A., Paul, F., Machguth, H., and Haeberli, W.: Comparing three different methods to model scenarios of future glacier change in the Swiss Alps, Ann. Glaciol., 54, 241-253, 2013.

López-Moreno, J. I., García-Ruiz, J. M., and Beniston, M.: Environmental change and water resources in the Pyrenees. Facts and future perspectives for Mediterranean mountains, Global Planet. Change, 61, 300-312, 2008.
López-Moreno, J. I., Goyette, S., and Beniston, M.: Impact of climate change on snowpack in the Pyrenees: horizontal spatial variability and vertical gradients, J. Hydrol., 374, 384-396, https://doi.org/10.1016/j.jhydrol.2009.06.049, 2009.

López-Moreno, J. I., Goyette, S., Vicente-Serrano, S. M., and Beniston, M.: Effects of climate change on the intensity and frequency of heavy snowfall events in the Pyrenees, Climatic Change, 105, 489-508, https://doi.org/10.1007/s10584010-9889-3, 2011.

López-Moreno, J. I., Pomeroy, J. W., Revuelto, J., and VicenteSerrano, S. M.: Response of snow processes to climate change: spatial variability in a small basin in the Spanish Pyrenees, Hydrol. Process., 27, 2637-2650, https://doi.org/10.1002/hyp.9408, 2012.

López-Moreno, J. I., Zabalza, J., Vicente-Serrano, S. M., Revuelto, J., Gilaberte, M., Azorin-Molina, C., Morán-Tejeda, E. García-Ruiz, J. M., and Tague, C.: Impact of climate and land use change on water availability and reservoir management; Scenarios in the upper Aragón River, Spanish Pyrenees, Sci. Total Environ., 493, 1222-1231, 2014.

López-Moreno, J. I., Revuelto, J., Rico, I., Chueca-Cía, J., Julián, A., Serreta, A., Serrano, E., Vicente-Serrano, S. M. Azorín-Molina, C., Alonso-González, E., and García-Ruiz, J. M.: Thinning of the Monte Perdido Glacier in the Spanish Pyrenees since 1981, The Cryosphere, 10, 681-694, https://doi.org/10.5194/tc-10-681-2016, 2016.

Lugon, R. and Stoffel, M.: Rock-glacier dynamics and magnitudefrequency relations of debris flows in a high-elevation watershed: Ritigraben, Swiss Alps, Global Planet. Change, 73, 202-210, 2010.

Lüthi, M. P. and Funk, M.: Dating ice cores from a high Alpine glacier with a flow model for cold firn, Ann. Glaciol., 31, 69-79, 2000.

Lüthi, R., Phillips, M., and Lehning, M.: Estimating non-conductive heat flow leading to intra-permafrost talik formation at the Ritigraben Rock Glacier (Western Swiss Alps), Permafrost Periglac., 28, 183-194, https://doi.org/10.1002/ppp.1911, 2017.

Magnin, F., Westermann, S., Pogliotti, P., Ravanel, L., Deline, P., and Malet, E.: Snow control on active layer thickness in steep alpine rock walls (Aiguille du Midi, 3842 ma.s.1., Mont Blanc massif), Catena, 149, 648-662, 2017.

Magnusson, J., Jonas, T., López-Moreno, J. I., and Lehning, M.: Snow cover response to climate change in a high alpine and half-glacierized basin in Switzerland, Hydrol. Res., 41, 230-240, https://doi.org/10.2166/nh.2010.115, 2010.

Magnusson, J., Farinotti, D., Jonas, T., and Bavay, M.: Quantitative evaluation of different hydrological modelling approaches in a partly glacierized Swiss watershed, Hydrol. Process., 25, 20712084, 2011.

Magnusson, J., Wever, N., Essery, R., Helbig, N., Winstral, A., and Jonas, T.: Evaluating snow models with varying process representations for hydrological applications, Water Resour. Res., 51, 2707-2723, https://doi.org/10.1002/2014WR016498, 2015.

Marke, T., Strasser, U., Hanzer, F., Wilcke, R., Gobiet, A., and Stötter, J.: Scenarios of future snow conditions in Styria (Austrian Alps), J. Hydrometeorol., 16, 261-277, https://doi.org/10.1175/JHM-D-14-0035.1, 2015.

Marmy, A., Rajczak, J., Delaloye, R., Hilbich, C., Hoelzle, M., Kotlarski, S., Lambiel, C., Noetzli, J., Phillips, M., Salzmann, N., 
Staub, B., and Hauck, C.: Semi-automated calibration method for modelling of mountain permafrost evolution in Switzerland, The Cryosphere, 10, 2693-2719, https://doi.org/10.5194/tc-102693-2016, 2016.

Marshall, H. P., Schneebeli, M., and Koh, G.: Snow stratigraphy measurements with high-frequency FMCW radar: comparison with snow micro-penetrometer, Cold Reg. Sci. Technol., 47, 108-117, https://doi.org/10.1016/j.coldregions.2006.08.008, 2007.

Marti, R., Gascoin, S., Houet, T., Ribière, O., Laffly, D., Condom, T., Monnier, S., Schmutz, M., Camerlynck, C., Tihay, J. P., Soubeyroux, J. M., and René, P.: Evolution of Ossoue Glacier (French Pyrenees) since the end of the Little Ice Age, The Cryosphere, 9, 1773-1795, https://doi.org/10.5194/tc-9-1773$2015,2015$.

Martin, E., Giraud, G., Lejeune, Y., and Boudart, G.: Impact of a climate change on avalanche hazard, Ann. Glaciol., 32, 163-167, https://doi.org/10.3189/172756401781819292, 2001.

Marty, C.: Regime shift of snow days in Switzerland, Geophys. Res. Lett., 35, L12501, https://doi.org/10.1029/2008GL033998, 2008.

Marty, C. and Blanchet, J.: Long-term changes in annual maximum snow depth and snowfall in Switzerland based on extreme value statistics, Climatic Change, 111, 705-721, 2012.

Marty, C., Schlögl, S., Bavay, M., and Lehning, M.: How much can we save? Impact of different emission scenarios on future snow cover in the Alps, The Cryosphere, 11, 517-529, https://doi.org/10.5194/tc-11-517-2017, 2017a.

Marty, C., Tilg, A.-M., and Jonas, T.: Recent evidence of large scale receding snow water equivalents in the European Alps, J. Hydrometeorol., 18, 1021-1031, https://doi.org/10.1175/jhm-d-160188.1, 2017b.

Martz, F., Vuosku, J., Ovaskainen, A., Stark, S., and Rautio, P.: The snow must go on: ground ice encasement, snow compaction and absence of snow differently cause soil hypoxia, $\mathrm{CO}_{2}$ accumulation and tree seedling damage in boreal forest, PLoS One, 11, e0156620, https://doi.org/10.1371/journal.pone.0156620, 2016.

Marzeion, B. and Nesje, A.: Spatial patterns of North Atlantic Oscillation influence on mass balance variability of European glaciers, The Cryosphere, 6, 661-673, https://doi.org/10.5194/tc6-661-2012, 2012.

Marzeion, B., Jarosch, A. H., and Hofer, M.: Past and future sealevel change from the surface mass balance of glaciers, The Cryosphere, 6, 1295-1322, https://doi.org/10.5194/tc-6-12952012, 2012.

McGuire, A. D., Koven, C., Lawrence, D. M., Clein, J. S., Xia, J., Beer, C., Burke, E., Chen, G., Chen, X., Delire, C., Jafarov, E., MacDougall, A. H., Marchenko, S., Nicolsky, D., Peng, S., Rinke, A., Saito, K., Zhang, W., Alkama, R., Bohn, T. J., Ciais, P., Decharme, B., Ekici, A., Gouttevin, I., Hajima, T., Hayes, D. J.,Ji, D., Krinner, G., Lettenmaier, D. P., Luo, Y., Miller, P. A., Moore, J. C., Romanovsky, V., Schädel, C., Schaefer, K., Schuur, E. A. G., Smith, B., Sueyoshi, T., and Zhuang, Q.: Variability in the sensitivity among model simulations of permafrost and carbon dynamics in the permafrost region between 1960 and 2009, Global Biogeochem. Cy., 30, 1015-1037, 2016.

Mernild, S. H., Lipscomb, W. H., Bahr, D. B., Radić, V., and Zemp, M.: Global glacier changes: a revised assessment of committed mass losses and sampling uncertainties, The Cryosphere, 7, 1565-1577, https://doi.org/10.5194/tc-7-1565-2013, 2013.
Micu, D.: Snow pack in the Romanian Carpathians under changing climatic conditions, Meteorol. Atmos. Phys., 105, 1-16, https://doi.org/10.1007/s00703-009-0035-6, 2009.

Mignatti, A., Casagrandi, R., Provenzale, A., von Hardenberg, A., and Gatto, M.: Sex- and age-structured models for Alpine ibex Capra ibex ibex population dynamics, Wildlife Biol., 18, 318332, 2012.

Millar, C. I., Westfall, R. D., and Delany, D. L.: Thermal and hydrologic attributes of rock glaciers and periglacial talus landforms: Sierra Nevada, California, USA, Quatern. Int., 310, 169-180, 2013.

Mock, C. J. and Birkeland, K. W.: Snow avalanche climatology of the western United States mountain ranges, B. Am. Meteorol. Soc., 81, 2367-2392, 2000.

Morán-Tejeda, E., López-Moreno, J. I., and Beniston, M.: The changing roles of temperature and precipitation on snowpack variability in Switzerland as a function of elevation, Geophys. Res. Lett., 40, 2131-2136, https://doi.org/10.1002/grl.50463, 2013.

Morán-Tejeda, E., Lorenzo-Lacruz, J., López-Moreno, J. I., Rahman, K., and Beniston, M.: Streamflow timing of mountain rivers in Spain: recent changes and future projections, J. Hydrol., 517, 1114-1127, https://doi.org/10.1016/j.jhydrol.2014.06.053, 2014.

Morán-Tejeda, E., López-Moreno, J. I., Stoffel, M., and Beniston, M.: Rain-on-snow events in Switzerland: recent observations and projections for the 21st century, Clim. Res., 71, 111-125, 2016.

Mori, M., Watanabe, M., Shiogama, H., Inoue, J., and Kimoto, M.: Robust Arctic sea-ice influence on the frequent Eurasian cold winters in past decades, Nat. Geosci., 7, 869-873, https://doi.org/10.1038/ngeo2277, 2014.

Mott, R., Schirmer, M., Bavay, M., Grünewald, T., and Lehning, M.: Understanding snow-transport processes shaping the mountain snow-cover, The Cryosphere, 4, 545-559, https://doi.org/10.5194/tc-4-545-2010, 2010.

Mott, R., Schirmer, M., and Lehning, M.: Scaling properties of wind and snow depth distribution in an Alpine catchment, J. Geophys. Res., 116, D06106, https://doi.org/10.1029/2010JD014886, 2011.

Mott, R., Scipion, D., Schneebeli, M., Dawes, N., Berne, A., and Lehning, M.: Orographic effects on snow deposition patterns in mountainous terrain, J. Geophys. Res.-Atmos., 119, 1419-1439, https://doi.org/10.1002/2013jd019880, 2014.

Mountain Agenda: Mountains of the World. Water Towers for the 21st Century, Prepared for the United Nations Commission on Sustainable Development, Institute of Geography, University of Berne (Centre for Development and Environment and Group for Hydrology) and Swiss Agency for Development and Cooperation, Paul Haupt Publishers, Bern, Switzerland, 32 pp., 1998.

Müller, J., Gärtner-Roer, I., Thee, P., and Ginzler, C.: Accuracy assessment of airborne photogrammetrically derived highresolution digital elevation models in a high mountain environment, ISPRS J. Photogramm., 98, 58-69, 2014.

Naaim, M., Durand, Y., Eckert, N., and Chambon, G.: Dense avalanche friction coefficients: influence of physical properties of snow, J. Glaciol., 59, 771-782, 2013.

NCCS: Climate in Norway 2100 - a knowledge base for climate adaptations, NCCS report no. 1/2017, ISSN nr. 2387-3027, Norwegian Centre for Climate Services, Oslo, Norway, 2017. 
Necsoiu, M., Onaca, A., Wigginton, S., and Urdea, P.: Rock glacier dynamics in Southern Carpathian Mountains from highresolution optical and multi-temporal SAR satellite imagery, Remote Sens. Environ., 177, 21-36, 2016.

Nelson, D. R., Adger, N. W., and Brown, K.: Adaptation to environmental change: contributions of a resilience framework, Annu. Rev. Env. Resour., 32, 395-419, 2007.

Nicolet, G., Eckert, N., Morin, S., and Blanchet, J.: Decreasing spatial dependence in extreme snowfall in the French Alps since 1958 under climate change, J. Geophys. Res.-Atmos., 121, 8297-8310, 2016.

Nikolova, N., Faško, P., Lapin, M., and Švec, M.: Changes in snowfall/precipitation-day ratio in Slovakia and their linkages with air temperature and precipitation, Contrib. Geophys. Geod., 43, 141-155, https://doi.org/10.2478/congeo-2013-0009, 2013.

Nitu, R.: Solid Precipitation Intercomparison Experiment, WMO SPICE: Engagements and Progress: TECO-2014, World Meteorological Organisation, IOM, Geneva, Switzerland, 116, 2014.

Noetzli, J., Christiansen, H. H., Gugliemin, M., Romanovsky, V. E., Shiklomanov, N. I., Smith, S. L., and Zhao, L.: Permafrost thermal state (in "State of the Climate in 2015"), B. Am. Meteorol. Soc., 97, 173-226, 2016.

O'Gorman, P. A.: Contrasting responses of mean and extreme snowfall to climate change, Nature, 512, 416-418, https://doi.org/10.1038/nature13625, 2014.

Oerlemans, J.: A flowline model for Nigardsbreen, Norway: projection of future glacier length based on dynamic calibration with the historic record, Ann. Glaciol., 24, 382-389, 1997.

Oerlemans, J., Anderson, B., Hubbard, A., Huybrechts, P., Johannesson, T., Knap, W. H., Schmeits, M., Stroeven, A. P., van de Wal, R. S. W., Wallinga, J., and Zuo, Z.: Modelling the response of glaciers to climate warming, Clim. Dynam., 14, 267-274, 1998.

Oerlemans, J., Giessen, R. H., and van den Broeke, M. R.: Retreating alpine glaciers: increased melt rates due to accumulation of dust (Vadret da Morteratsch, Switzerland), J. Glaciol., 55, 729736, https://doi.org/10.3189/002214309789470969, 2009.

Orlowsky, B. and Seneviratne, S. I.: On the spatial representativeness of temporal dynamics at European weather stations, Int. J. Climatol., 34, 3154-3160, https://doi.org/10.1002/joc.3903, 2014.

Parajka, J., Viglione, A., Rogger, M., Salinas, J. L., Sivapalan, M., and Blöschl, G.: Comparative assessment of predictions in ungauged basins - Part 1: Runoff-hydrograph studies, Hydrol. Earth Syst. Sci., 17, 1783-1795, https://doi.org/10.5194/hess-171783-2013, 2013.

Peizhen, Z., Molnar, P., and Downs, W. R.: Increased sedimentation rates and grain sizes 2-4 Myr ago due to the influence of climate change on erosion rates, Nature, 410, 891-897, 2001.

Pellet, C., Hilbich, C., Marmy, A., and Hauck, C.: Soil moisture data for the validation of permafrost models using direct and indirect measurement approaches at three alpine sites, Front. Earth Sci., 3, 91, https://doi.org/10.3389/feart.2015.00091, 2016.

Pellicciotti, F., Brock, B., Strasser, U., Burlando, P., Funk, M., and Corripio, J.: An enhanced temperature-index glacier melt model including the shortwave radiation balance: development and testing for Haut Glacier d'Arolla, Switzerland, J. Glaciol., 51, 573$587,2005$.
Pellicciotti, F., Carenzo, M., Bordoy, R., and Stoffel, M.: Changes in glaciers in the Swiss Alps and impact on basin hydrology: current state of the art and future research, Sci. Total Environ., 493, 1152-1170, https://doi.org/10.1016/j.scitotenv.2014.04.022, 2014.

Peng, S., Ciais, P., Krinner, G., Wang, T., Gouttevin, I., McGuire, A. D., Lawrence, D., Burke, E., Chen, X., Decharme, B., Koven, C., MacDougall, A., Rinke, A., Saito, K., Zhang, W., Alkama, R., Bohn, T. J., Delire, C., Hajima, T., Ji, D., Lettenmaier, D. P., Miller, P. A., Moore, J. C., Smith, B., and Sueyoshi, T.: Simulated high-latitude soil thermal dynamics during the past 4 decades, The Cryosphere, 10, 179-192, https://doi.org/10.5194/tc-10-179-2016, 2016.

Pepin, N., Bradley, R. S., Diaz, H. F., Baraer, M., Caceres, E. B., Forsythe, N., Fowler, H., Greenwood, G., Hashmi, M. Z., Liu, X. D., Miller, J. R., Ning, L., Ohmura, A., Palazzi, E., Rangwala, I., Schöner, W., Severskiy, I., Shahgedanova, M., Wang, M. B., Williamson, S. N., and Yang, D. Q.: Elevationdependent warming in mountain regions of the world, Nat. Clim. Change, 5, 424-430, https://doi.org/10.1038/NCLIMATE2563, 2015.

PERMOS: Permafrost in Switzerland 2010/2011 to 2013/2014, Glaciological Report Permafrost No. 12-15 of the Cryospheric Commission of the Swiss Academy of Sciences, edited by: Noetzli, J., Luethi, R., and Staub, B., Cryospheric Commission of the Swiss Academy of Sciences (SCNAT), Bern, Switzerland, 86 pp., 2016.

Pettorelli, N., Pelletier, F., von Hardenberg, A., Festa-Bianchet, M., and Coteal, S. D.: Early onset of vegetation growth vs. rapid green-up: impacts on juvenile mountain ungulates, Ecology, 88 , 381-390, 2007.

Phillips, M., Wolter, A., Lüthi, R., Amann, F., Kenner, R., and Bühler, Y.: Rock slope failure in a recently deglaciated permafrost rock wall at Piz Kesch (Eastern Swiss Alps), February 2014, Earth Surf. Proc. Land., 42, 426-438, https://doi.org/10.1002/esp.3992, 2017.

Pielmeier, C., Techel, F., Marty, C., and Stucki, T.: Wet snow avalanche activity in the Swiss Alps - trend analysis for midwinter season, International Snow Science Workshop, Grenoble, France, 07-11 October 2013, 1240-1246, 2013.

Pinzer, B. R., Schneebeli, M., and Kaempfer, T. U.: Vapor flux and recrystallization during dry snow metamorphism under a steady temperature gradient as observed by time-lapse micro-tomography, The Cryosphere, 6, 1141-1155, https://doi.org/10.5194/tc-6-1141-2012, 2012.

Pogliotti, P., Guglielmin, M., Cremonese, E., Morra di Cella, U., Filippa, G., Pellet, C., and Hauck, C.: Warming permafrost and active layer variability at Cime Bianche, Western European Alps, The Cryosphere, 9, 647-661, https://doi.org/10.5194/tc-9-6472015, 2015.

Pons, M. R., San-Martín, D., Herrera, S., and Gutiérrez, J. M.: Snow trends in Northern Spain: analysis and simulation with statistical downscaling methods, Int. J. Climatol., 30, 1795-1806, https://doi.org/10.1002/joc.2016, 2010.

Post, E., Forchhammer, M. C., Bret-Harte, M. S., Callaghan, T. V., Christensen, T. Elberling, B., Fox, A. D., Gilg, O., Hik, D. S., Hoye, T. T., Ims, R. A., Jeppesen, E., Klein, D. R., Madsen, J., McGuire, A. D., Rysgaard, S., Schindler, D. E., Stirling, I., Tamstorf, M. P., Tyler, N. J. C., van der Wal, R., Welker, J., 
Wookey, P. A., Martin Schmidt, N., and Aastrup, P.: Ecological dynamics across the Arctic associated with recent climate change, Science, 325, 1355-1358, 2009.

Prasch, M., Marke, T., Strasser, U., and Mauser, W.: Large scale integrated hydrological modelling of the impact of climate change on the water balance with DANUBIA, Adv. Sci. Res., 7, 61-70, https://doi.org/10.5194/asr-7-61-2011, 2011.

Pütz, M., Gallati, D., Kytzia, S., Elsasser, H., Lardelli, C., Teich, M., Waltert, F., and Rixen, C.: Tourists' attitudes and regional economic impacts, Mt. Res. Dev., 31, 357-362, 2011.

Quevauviller, P., Barcelo, D., Beniston, M., Djordjevic, S., Froebrich, J., Harding, R. J., Ludwig, R., Navarra, A., Ortega, A. N., Roson, R., Sempere, D., Stoffel, M., van Lanen, H., and Werner, M.: Integration of research advances in modelling and monitoring in support of WFD river basin management planning in the context of climate change, Sci. Total Environ., 440, 167$177,2012$.

Radić, V. and Hock. R.: Modeling future glacier mass balance and volume changes using ERA-40 reanalysis and climate models: a sensitivity study at Storglaciären, Sweden, J. Geophys. Res., 111, F03003, https://doi.org/10.1029/2005JF000440, 2006.

Radić, V., Bliss, A., Beedlow, A. C., Hock, R., Miles, E., and Cogley, J. G.: Regional and global projections of twenty-first century glacier mass changes in response to climate scenarios from global climate models, Clim. Dynam., 42, 37-58, https://doi.org/10.1007/s00382-013-1719-7, 2014.

Räisänen, J. and Eklund, J.: 21st century changes in snow climate in Northern Europe: a high-resolution view from ENSEMBLES regional climate models, Clim. Dynam., 38, 2575-2591, https://doi.org/10.1007/s00382-011-1076-3, 2012.

Rajczak, J., Pall, P., and Schär, C.: Projections of extreme precipitation events in regional climate simulations for Europe and the Alpine region, J. Geophys. Res., 118, 3610-3626, https://doi.org/10.1002/jgrd.50297, 2013.

Rangecroft, S., Harrison, S., and Anderson, K.: Rock glaciers as water stores in the Bolivian Andes: an assessment of their hydrological importance, Arct. Antarct. Alp. Res., 47, 89-98, 2015.

Rasmussen, L. A. and Conway, H.: Influence of upper-air conditions on glaciers in Scandinavia, Ann. Glaciol., 42, 402-408, https://doi.org/10.3189/172756405781812727, 2005.

Rasmussen, R., Baker, B. Kochendorfer, J., Meyers, T., Landolt, S., Fischer, A. P., Black, J., Thériault, J. M., Kucera, P., Gochis, D., Smith, C., Nitu, R., Hall, M., Ikeda, K., and Gutmann, E.: How well are we measuring snow? The NOAA/FAA/NCAR Winter Precipitation Test Bed, B. Am. Meteorol. Soc., 93, 811-829, https://doi.org/10.1175/BAMS-D-11-00052.1, 2012.

Ravanel, L. and Deline, P.: Climate influence on rockfalls in highAlpine steep rockwalls: the north side of the Aiguilles de Chamonix (Mont Blanc massif) since the end of the "Little Ice Age", Holocene, 21, 357-365, 2011.

Ravanel, L., Allignol, F., Deline, P., Gruber, S., and Ravello, M.: Rock falls in the Mont Blanc Massif in 2007 and 2008, Landslides, 7, 493-501, 2010.

Ravanel, L., Deline, P., Lambiel, C., and Vincent, C.: Instability of a high alpine rock ridge: the lower areête des Cosmiques, Mont-Blanc massif, France, Geogr. Ann. A, 95, 51-66, https://doi.org/10.1111/geoa.12000, 2013.

Reid, P. C., Hari, R., Beaugrand, G., Livingstone, D. M., Marty, C., Straile, D., Barichivich, J., Goberville, E., Adrian, R., Aono, Y.,
Brown, R., Foster, J., Groisman, P., Hélaouët, P., Hsu, H.H., Kirby, R., Knight, J., Kraberg, A., Li, J., Lo, T.-T., Myneni, R. B., North, R. P., Pounds, J. A., Sparks, T., Stübi, R., Tian, Y., Wiltshire, K. H., Xiao, D., and Zhu, Z.: Global impacts of the 1980s regime shift, Glob. Change Biol., 22, 682-703, https://doi.org/10.1111/gcb.13106, 2016.

Reid, T. D. and Brock, B. W.: An energy-balance model for debriscovered glaciers including heat conduction through the debris layer, J. Glaciol., 56, 903-916, 2010.

Réveillet, M., Vincent, C., Six, D., and Rabatel, A.: Which empirical model is best suited to simulating glacier mass balances?, J. Glaciol., 63, 39-54, https://doi.org/10.1017/jog.2016.110, 2017.

Rico, I., Izaguirre, E., Cañadas-Serrano, E., and LópezMoreno, J. I.: Current glacier area in the Pyrenees: an updated assessment 2016, Pirineos, 172, e09, https://doi.org/10.3989/Pirineos.2017.172004, 2017.

Riediger, J., Breckling, B., Nuske, R. S., and Schröder, W.: Will climate change increase irrigation requirements in agriculture of Central Europe? A simulation study for Northern Germany, Environ. Sci. Europe, 26, 1-13, 2014.

Riseborough, D., Shiklomanov, N., Etzelmüller, B., Gruber, S., and Marchenko, S.: Recent advance in permafrost modelling, Permafrost Periglac., 19, 137-156, 2008.

Rixen, C., Teich, M., Lardelli, C., Gallati, D., Pohl, M., Pütz, M., and Bebi, P.: Winter tourism and climate change in the Alps: an assessment of resource consumption, snow reliability and future snowmaking potential, Mt. Res. Dev., 31, 229-236, 2011.

Röthlisberger, H.: Water pressure in intra- and subglacial channels, J. Glaciol., 11, 177-203, 1972.

Romanovsky, V. E., Smith, S. L., and Christiansen, H. H.: Permafrost thermal state in the polar Northern Hemisphere during the international polar year 2007-2009: a synthesis, Permafrost Periglac., 21, 181-200, 2010.

Roson, R. and Sartori, M.: Climate Change, Tourism and Water Resources in the Mediterranean: a General Equilibrium Analysis, Working Paper Series 51, Centre for Research on Energy and Environment Economics and Policy, Milan, Italy, 15 pp., 2012.

Rousselot, M., Durand, Y., Giraud, G., Mérindol, L., DombrowskiEtchevers, I., Déqué, M., and Castebrunet, H.: Statistical adaptation of ALADIN RCM outputs over the French Alps - application to future climate and snow cover, The Cryosphere, 6, 785805, https://doi.org/10.5194/tc-6-785-2012, 2012.

Sadovský, Z. and Sykora, M.: Snow load models for probabilistic optimization of steel frames, Cold Reg. Sci. Technol., 94, 13-20, 2013.

Salzmann, N., Machguth, H., and Linsbauer, A.: The Swiss Alpine glaciers' response to the global " $2{ }^{\circ} \mathrm{C}$ air temperature target", Environ. Res. Lett., 7, 044001, https://doi.org/10.1088/17489326/7/4/044001, 2012.

Schaefli, B., Hingray, B., and Musy, A.: Climate change and hydropower production in the Swiss Alps: quantification of potential impacts and related modelling uncertainties, Hydrol. Earth Syst. Sci., 11, 1191-1205, https://doi.org/10.5194/hess-11-11912007, 2007.

Schaldach, R., Koch, J., Aus der Beek, T., Kynast, E., and Flörke, M.: Current and future irrigation water requirements in pan-Europe: an integrated analysis of socio-economic and climate scenarios, Global Planet. Change, 94-95, 33-45, 2012. 
Scherler, M., Hauck, C., Hoelzle, M., and Salzmann, N.: Modeled sensitivity of two alpine permafrost sites to RCMbased climate scenarios, J. Geophys. Res.-Earth, 118, 780-794, https://doi.org/10.1002/jgrf.20069, 2013.

Scherler, M., Schneider, S., Hoelzle, M., and Hauck, C.: A twosided approach to estimate heat transfer processes within the active layer of the Murtèl-Corvatsch rock glacier, Earth Surf. Dynam. 2, 141-154, https://doi.org/10.5194/esurf-2-141-2014, 2014.

Scherrer, S. C. and Appenzeller, C.: Swiss alpine snow pack variability: major patterns and links to local climate and large-scale flow, Clim. Res., 32, 187-199, https://doi.org/10.3354/cr032187, 2006.

Scherrer, S. C., Appenzeller, C., and Laternser, M.: Trends in Swiss Alpine snow days: the role of local- and largescale climate variability, Geophys. Res. Lett., 31, L13215, https://doi.org/10.1029/2004GL020255, 2004.

Scherrer, S. C., Wüthrich, C., Croci-Maspoli, M., Weingartner, R., and Appenzeller, C.: Snow variability in the Swiss Alps 1864-2009, Int. J. Climatol., 33, 3162-3173, https://doi.org/10.1002/joc.3653, 2013.

Schirmer, M., Lehning, M., and Schweizer, J.: Statistical forecasting of regional avalanche danger using simulated snow-cover data, J. Glaciol., 55, 761-768, 2009.

Schläppy, R., Eckert, N., Jomelli, R. Stoffel, M., Grancher, D., Brunstein, D., Naaim, M., and Deschatres, M.: Validation of extreme snow avalanches and related return periods derived from a statistical-dynamical model using tree-ring based techniques, Cold Reg. Sci. Technol., 99, 12-26, 2014.

Schläppy, R., Jomelli, V., Eckert, N., Stoffel, M., Grancher, D., Brunstein, D., Corona, C., and Deschatres, M.: Can we infer avalanche-climate relations using tree-ring data? Case studies from the French Alps, Reg. Environ. Change, 16, 629-642, 2016.

Schlögl, S., Marty, C., Fierz, C., and Lehning, M.: Sensitivity of Alpine3D modeled snow cover to modifications in DEM resolution, station coverage and meteorological input quantities, Environ. Modell. Softw., 83, 387-396, 2016.

Schmid, M.-O., Baral, P., Gruber, S., Shahi, S., Shrestha, T., Stumm, D., and Wester, P.: Assessment of permafrost distribution maps in the Hindu Kush Himalayan region using rock glaciers mapped in Google Earth, The Cryosphere, 9, 20892099, https://doi.org/10.5194/tc-9-2089-2015, 2015.

Schmocker-Fackel, P. and Naef, F.: Changes in flood frequencies in Switzerland since 1500, Hydrol. Earth Syst. Sci., 14, 1581-1594, https://doi.org/10.5194/hess-14-1581-2010, 2010.

Schmucki, E., Marty, C., Fierz, C., and Lehning, M.: Simulations of 21 st century snow response to climate change in Switzerland from a set of RCMs, Int. J. Climatol., 35, 3262-3273, https://doi.org/10.1002/joc.4205, 2015a.

Schmucki, E., Marty, C., Fierz, C., Weingartner, R., and Lehning, M.: Impact of climate change in Switzerland on socioeconomic snow indices, Theor. Appl. Climatol., 1-15, https://doi.org/10.1007/s00704-015-1676-7, 2015 b.

Schneuwly-Bollschweiler, M. and Stoffel, M.: Hydrometeorological triggers of periglacial debris flows - a reconstruction dating back to 1864, J. Geophys. Res.-Earth, 117, F02033, https://doi.org/10.1029/2011JF002262, 2012.
Schoof, C.: Ice-sheet acceleration driven by melt supply variability, Nature, 468, 803-806, https://doi.org/10.1038/nature09618, 2010.

Schrott, L.: Some geomorphological-hydrological characteristics of rock glaciers in the Andes, San Juan, Argentina, Z. Geomorphol. Supp., 104, 161-173, 1996.

Schwanghart, W., Worni, R., Huggel, C., Stoffel, M., and Korup, O.: Uncertainties at the water-energy nexus - the case of Himalayan hydropower and glacial lake outburst floods, Environ. Res. Lett., 11, 074005, https://doi.org/10.1088/17489326/11/7/074005, 2016.

Schweizer, J., Jamieson, J. B., and Schneebeli, M.: Snow avalanche formation, Rev. Geophys., 41, 1016, https://doi.org/10.1029/2002RG000123, 2003.

Scipion, D. E., Mott, R., Lehning, M., Schneebeli, M., and Berne, A.: Seasonal small-scale spatial variability in alpine snowfall and snow accumulation, Water Resour. Res., 49, 14461457, https://doi.org/10.1002/wrcr.20135, 2013.

Scotti, R., Crosta, G. B., and Villa, A.: Destabilisation of creeping permafrost: the Plator Rock Glacier Case Study (central Italian Alps), Permafrost Periglac., 28, 224-236, https://doi.org/10.1002/ppp.1917, 2016.

Serquet, G., Marty, C., Dulex, J.-P., and Rebetez, M.: Seasonal trends and temperature dependence of the snowfall/precipitationday ratio in Switzerland, Geophys. Res. Lett., 38, 14-18, https://doi.org/10.1029/2011GL046976, 2011.

SGHL Schweizerische Gesellschaft für Hydrologie und Limnologie/Chy Hydrologische Kommission (Eds.): Auswirkung der Klimaänderung auf die Wasserkraftnutzung - Synthesebericht, Beiträge zur Hydrologie der Schweiz, 38, Bern, 28 pp., 2011.

Sillmann, J., Kharin, V. V., Zhang, X., Zwiers, F. W., and Bronaugh, D.: Climate extremes indices in the CMIP5 multimodel ensemble: Part 1. Model evaluation in the present climate, J. Geophys. Res.-Atmos., 118, 1716-1733, 2013.

Six, D. and Vincent, C.: Sensitivity of mass balance and equilibrium line elevation to climate change in the French Alps, J. Glaciol., 60, 867-878, https://doi.org/10.3189/2014JoG14J014, 2014.

Skaugen, T., Stranden, H. B., and Saloranta, T.: Trends in snow water equivalent in Norway (1931-2009), Hydrol. Res., 43, 489, https://doi.org/10.2166/nh.2012.109, 2012.

Smiraglia, C. and Diolaiuti, G.: The new Italian glacier Inventory, EV-K2-CNR, Bergamo Publ., Bergamo, Italy, 400 pp., 2015.

Smith, P. C., Calanca, P., and Fuhrer, J.: A simple scheme for modelling irrigation water requirements at the regional scale applied to an alpine river catchment, Water, 4, 869-886, 2012.

Smith, P. C., Heinrich, G., Suklitsch, M., Gobiet, A., Stoffel, M., and Fuhrer, J.: Station-scale bias correction and uncertainty analysis for the estimation of irrigation water requirements in the Swiss Rhone catchment under climate change, Climatic Change, 127, 521-534, 2014.

Sold, L., Huss, M., Hoelzle, M., Andereggen, H., Joerg, P. C., and Zemp, M.: Methodological approaches to infer end-of-winter snow distribution on alpine glaciers, J. Glaciol., 59, 1047-1059, https://doi.org/10.3189/2013JoG13J015, 2013.

Sorg, A., Kääb, A., Roesch, A., Bigler, C., and Stoffel, M.: Contrasting responses of Central Asian rock glaciers to global warming, Sci. Rep.-UK, 5, 8228, https://doi.org/10.1038/srep08228, 2015.

Sovilla, B., Kern, M., and Schaer, M.: Slow drag in wet snow avalanche flow, J. Glaciol., 56, 587-592, 2010. 
Spandre, P., François, H., Morin, S., and George-Marcelpoil, E.: Snowmaking in the French Alps: climatic context, existing facilities and outlook, Journal of Alpine Research, 103, 2, https://doi.org/10.4000/rga.2913, 2015.

Spandre, P., François, H., George-Marcelpoil, E., and Morin, S.: Panel based assessment of snow management operations in french ski resorts, Journal of Outdoor Recreation and Tourism, 16, 24-36, https://doi.org/10.1016/j.jort.2016.09.002, 2016.

Staub, B., Hasler, A., Noetzli, J., and Delaloye, R.: Gap-filling algorithm for ground surface temperature data measured in permafrost and periglacial environments, Permafrost Periglac., 28, 275-285, https://doi.org/10.1002/ppp.1913, 2016.

Steger, C., Kotlarski, S., Jonas, T., and Schaer, C.: Alpine snow cover in a changing climate: a regional climate model perspective, Clim. Dynam., 41, 735-754, https://doi.org/10.1007/s00382-012-1545-3, 2013.

Steiger, R.: The impact of climate change on ski season length and snow-making requirements in Tyrol, Austria, Clim. Res., 43, 251-262, 2010.

Steiger, R. and Abegg, B.: The sensitivity of Austrian ski areas to climate change, Tourism Planning and Development, 10, 480493, https://doi.org/10.1080/21568316.2013.804431, 2013.

Stoffel, M.: Magnitude-frequency relationships of debris flows a case study based on field surveys and tree-ring records, Geomorphology, 116, 67-76, 2010.

Stoffel, M. and Corona, C.: Dendroecological dating of geomorphic disturbance in trees, Tree-Ring Res., 70, 3-20, 2014.

Stoffel, M. and Huggel, C.: Effects of climate change on mass movements in mountain environments, Prog. Phys. Geog., 36, 421-439, 2012.

Stoffel, M., Bollschweiler, M., and Hassler, G. R.: Differentiating past events on a cone influenced by debris-flow and snow avalanche activity - a dendrogeomorphological approach, Earth Surf. Proc. Land., 31, 1424-1437, 2006.

Stoffel, M., Conus, D., Grichting, M. A., Lièvre, I., and Maître, G.: Unraveling the patterns of late Holocene debris-flow activity on a cone in the central Swiss Alps: chronology, environment and implications for the future, Global Planet. Change, 60, 222-234, 2008.

Stoffel, M., Bollschweiler, M., Butler, D., and Luckman, B.: Tree rings and natural hazards: a state-of-art, in: Advances in Global Change Research, 41, edited by: Beniston, M., Springer, Dordrecht, the Netherlands, 2010.

Stoffel, M., Bollschweiler, M., and Beniston, M.: Rainfall characteristics for periglacial debris flows in the Swiss Alps: past incidences - potential future evolutions, Climatic Change, 105, 263280, 2011.

Stoffel, M., Mendlik, T., Schneuwly-Bollschweiler, M., and Gobiet, A.: Possible impacts of climate change on debris-flow activity in the Swiss Alps, Climatic Change, 122, 141-155, 2014a.

Stoffel, M., Tiranti, D., and Huggel, C.: Climate change impacts on mass movements - case studies from the European Alps, Sci. Total Environ., 493, 1255-1266, 2014b.

Stoffel, M., Wyzga, B., and Marston, R. A.: Floods in mountain environments, Geomorphology, 272, 1-9, 2016.

Strasser, U., Marke, T., Braun, L., Escher-Vetter, H., Juen, I., Kuhn, M., Maussion, F., Mayer, C., Nicholson, L., Niedertscheider, K., Sailer, R., Stötter, J., Weber, M., and Kaser, G.: The Rofental: a high Alpine research basin (1890-3770 ma.s.1.) in the Ötztal Alps (Austria) with over 150 years of hydrometeorological and glaciological observations, Earth Syst. Sci. Data, 10, 151-171, https://doi.org/10.5194/essd-10-151-2018, 2018.

Strozzi, T., Delaloye, R., Kääb, A., Ambrosi, C., Perruchoud, E., and Wegmüller, U.: Combined observations of rock mass movements using satellite SAR interferometry, differential GPS, airborne digital photogrammetry, and airborne photography interpretation, J. Geophys. Res., 115, F01014, https://doi.org/10.1029/2009JF001311, 2010.

Sultana, R., Hsu, K.-L., Li, J., and Sorooshian, S.: Evaluating the Utah Energy Balance (UEB) snow model in the Noah land-surface model, Hydrol. Earth Syst. Sci., 18, 3553-3570, https://doi.org/10.5194/hess-18-3553-2014, 2014.

Supper, R., Ottowitz, D., Jochum, B., Roemer, A., Pfeiler, S., Kauer, S., Keushnig, M., and Ita, A.: Geoelectrical monitoring of frozen ground and permafrost in alpine areas: field studies and considerations towards an improved measuring technology, Near-Surface Geophysics, 12, 93-115, https://doi.org/10.3997/1873-0604.2013057, 2014.

Teich, M., Marty, C., Gollut, C., Grêt-Regamey, A., and Bebi, P.: Snow and weather conditions associated with avalanche releases in forests: rare situations with decreasing trends during the last 41 years, Cold Reg. Sci. Technol., 83-84, 77-88, https://doi.org/10.1016/j.coldregions.2012.06.007, 2012.

Terzago, S., Fratianni, S., and Cremonini, R.: Winter precipitation in Western Italian Alps (1926-2010), Meteorol. Atmos. Phys., 119, 125-136, https://doi.org/10.1007/s00703-012-02317, 2013.

Terzago, S., von Hardenberg, J., Palazzi, E., and Provenzale, A.: Snow water equivalent in the Alps as seen by gridded data sets, CMIP5 and CORDEX climate models, The Cryosphere, 11, 1625-1645, https://doi.org/10.5194/tc-11-1625-2017, 2017.

Thibert, E., Eckert, N., and Vincent, C.: Climatic drivers of seasonal glacier mass balances: an analysis of 6 decades at Glacier de Sarennes (French Alps), The Cryosphere, 7, 47-66, https://doi.org/10.5194/tc-7-47-2013, 2013.

Uhlmann, B., Goyette, S., and Beniston, M.: Sensitivity analysis of snow patterns in Swiss ski resorts to shifts in temperature, precipitation and humidity under conditions of climate change, Int. J. Climatol., 29, 1048-1055, https://doi.org/10.1002/joc.1786, 2009.

Valt, M. and Cianfarra, P.: Recent snow cover variability in the Italian Alps, Cold Reg. Sci. Technol., 64, 146-157, https://doi.org/10.1016/j.coldregions.2010.08.008, 2010.

van den Hurk, B., Kim, H., Krinner, G., Seneviratne, S. I., Derksen, C., Oki, T., Douville, H., Colin, J., Ducharne, A., Cheruy, F., Viovy, N., Puma, M. J., Wada, Y., Li, W., Jia, B., Alessandri, A., Lawrence, D. M., Weedon, G. P., Ellis, R., Hagemann, S., Mao, J., Flanner, M. G., Zampieri, M., Materia, S., Law, R. M., and Sheffield, J.: LS3MIP (v1.0) contribution to CMIP6: the Land Surface, Snow and Soil moisture Model Intercomparison Project - aims, setup and expected outcome, Geosci. Model Dev., 9, 2809-2832, https://doi.org/10.5194/gmd-9-2809-2016, 2016.

van der Schrier, G., Briffa, K. R., Jones, P. D., and Osborn, T. J.: Summer moisture variability across Europe, J. Climate, 19, 2818-2834, https://doi.org/10.1175/JCLI3734.1, 2006.

Vincent, C. and Moreau, L.: Sliding velocity fluctuations and subglacial hydrology over the last two decades on Argen- 
tière glacier, Mont Blanc area, J. Glaciol., 62, 805-815, https://doi.org/10.1017/jog.2016.35, 2016.

Vionnet, V., Brun, E., Morin, S., Boone, A., Faroux, S., Le Moigne, P., Martin, E., and Willemet, J.-M.: The detailed snowpack scheme Crocus and its implementation in SURFEX v7.2, Geosci. Model Dev., 5, 773-791, https://doi.org/10.5194/gmd-5773-2012, 2012.

Viviroli, D., Dürr, H. H., Messerli, B., Meybeck, M., and Weingartner, R.: Mountains of the world - water towersfor humanity: typology, mapping and global significance, Water Resour. Res., 43, W07447, https://doi.org/10.1029/2006WR005653, 2007.

Wagner, T., Themeß1, M., Schüppel, A., Gobiet, A., Stigler, H., and Birk, S.: Impacts of climate change on stream flow and hydro power generation in the Alpine region, Environ. Earth Sci., 76, https://doi.org/10.1007/s12665-016-6318-6, 2017.

Weber, M. and Prasch, M.: Einfluss der Gletscher auf das Abflussregime (des Einzugsgebiets der Oberen Donau) in der Vergangenheit und der Zukunft, in: Global Change Atlas. Einzugsgebiet Obere Donau, GLOWA-Danube-Projekt, München, 2009.

Wehner, M. F., Smith, R. L., Bala, G., and Duffy, P.: The effect of horizontal resolution on simulation of very extreme US precipitation events in a global atmosphere model, Clim. Dynam., 34, 241-247, 2010.

Westermann, S., Schuler, T. V., Gisnås, K., and Etzelmüller, B.: Transient thermal modeling of permafrost conditions in Southern Norway, The Cryosphere, 7, 719-739, https://doi.org/10.5194/tc7-719-2013, 2013.

Westermann, S., Østby, T. I., Gisnås, K., Schuler, T. V., and Etzelmüller, B.: A ground temperature map of the North Atlantic permafrost region based on remote sensing and reanalysis data, The Cryosphere, 9, 1303-1319, https://doi.org/10.5194/tc9-1303-2015, 2015.

Westermann, S., Langer, M., Boike, J., Heikenfeld, M., Peter, M., Etzelmüller, B., and Krinner, G.: Simulating the thermal regime and thaw processes of ice-rich permafrost ground with the landsurface model CryoGrid 3, Geosci. Model Dev., 9, 523-546, https://doi.org/10.5194/gmd-9-523-2016, 2016.

Wever, N., Fierz, C., Mitterer, C., Hirashima, H., and Lehning, M.: Solving Richards Equation for snow improves snowpack meltwater runoff estimations in detailed multi-layer snowpack model, The Cryosphere, 8, 257-274, https://doi.org/10.5194/tc-8-2572014, 2014.

Wever, N., Würzer, S., Fierz, C., and Lehning, M.: Simulating ice layer formation under the presence of preferential flow in layered snowpacks, The Cryosphere, 10, 2731-2744, https://doi.org/10.5194/tc-10-2731-2016, 2016.

WGMS: Global Glacier Change Bulletin No. 1 (2012-2013), edited by: Zemp, M., Gärtner-Roer, I., Nussbaumer, S. U., Hüsler, F., Machguth, H., Mölg, N., Paul, F., and Hoelzle, M., ICSU(WDS)/IUGG(IACS)/UNEP/UNESCO/WMO, World Glacier Monitoring Service, Zurich, Switzerland, 230 pp., Publication based on database version: https://doi.org/10.5904/wgmsfog-2015-11, 2015.

Wicky, J. and Hauck, C.: Numerical modelling of convective heat transport by air flow in permafrost talus slopes, The Cryosphere, 11, 1311-1325, https://doi.org/10.5194/tc-11-1311-2017, 2017.

Wikle, C. K.: Hierarchical models in environmental science, Int. Stat. Rev., 71, 181-199, 2003.
Wilcox, E. M. and Donner, L. J.: The frequency of extreme rain events in satellite rain-rate estimates and an atmospheric general circulation model, J. Climate, 20, 53-69, 2007.

Winsvold, S. H., Andreassen, L. M., and Kienholz, C.: Glacier area and length changes in Norway from repeat inventories, The Cryosphere, 8, 1885-1903, https://doi.org/10.5194/tc-8-18852014, 2014.

Wirz, V., Beutel, J., Gruber, S., Gubler, S., and Purves, R. S.: Estimating velocity from noisy GPS data for investigating the temporal variability of slope movements, Nat. Hazards Earth Syst. Sci., 14, 2503-2520, https://doi.org/10.5194/nhess14-2503-2014, 2014.

Wirz, V., Gruber, S., Purves, R. S., Beutel, J., GärtnerRoer, I., Gubler, S., and Vieli, A.: Short-term velocity variations at three rock glaciers and their relationship with meteorological conditions, Earth Surf. Dynam., 4, 103-123, https://doi.org/10.5194/esurf-4-103-2016, 2016.

Worni, R., Huggel, C., Clague, J., Schaub, Y., and Stoffel, M.: Coupling glacial lake impact, dam breach, and flood processes: a modeling perspective, Geomorphology, 224, 161-176, https://doi.org/10.1016/j.geomorph.2014.06.031, 2014.

Wu, W.-Y., Lan, C.-W., Lo, M.-H., Reager, J. T., and Famiglietti, J. S.: Increases in the annual range of soil water storage at northern middle and high latitudes under global warming, Geophys. Res. Lett., 42, 3903-3910, https://doi.org/10.1002/2015GL064110, 2015.

Würzer, S., Jonas, T., Wever, N., and Lehning, M.: Influence of initial snowpack properties on runoff formation during rain-on-snow events, J. Hydrometeorol., 17, 1801-1815, https://doi.org/10.1175/JHM-D-15-0181.1, 2016.

Würzer, S., Wever, N., Juras, R., Lehning, M., and Jonas, T.: Modelling liquid water transport in snow under rain-on-snow conditions - considering preferential flow, Hydrol. Earth Syst. Sci., 21, 1741-1756, https://doi.org/10.5194/hess-21-1741-2017, 2017.

Yang., D., Kane, D., Zhang., Z., Legates, D., and Goodison, B.: Bias corrections of long-term (1973-2004) daily precipitation data over the northern regions, Geophys. Res. Lett., 32, L19501, https://doi.org/10.1029/2005GL024057, 2005.

Zampieri, M., Scoccimarro, E., and Gualdi, S.: Atlantic influence on spring snowfall over the Alps in the past 150 years, Environ. Res. Lett., 8, 034026, https://doi.org/10.1088/1748-9326/8/3/034026, 2013.

Zekollari, H., Fürst, J. J., and Huybrechts, P.: Modelling the evolution of Vadret da Morteratsch, Switzerland, since the Little Ice Age and into the future, J. Glaciol., 60, 1155-1168, 2014.

Zemp, M., Haeberli, W., Hoelzle, M., and Paul, F.: Alpine glaciers to disappear within decades?, Geophys. Res. Lett., 33, L13504, https://doi.org/10.1029/2006GL026319, 2006.

Zemp, M., Hoelzle, M., and Haeberli, W.: Six decades of glacier mass-balance observations: a review of the worldwide monitoring network, Ann. Glaciol., 50, 101-111, 2009.

Zemp, M., Frey, H. Gärtner-Roer, I., Nussbaumer, S. U., Hoelzle, M., Paul, F., Haeberli, W., Denzinger, F., Ahlstrøm, A. P., Anderson, B., Bajracharya, S., Baroni, C., Braun, L. N., Cáceres, B. E., Casassa, G., Cobos, G., Dávila, L. R., Delgado Granados, H., Demuth, M. N., Espizua, L., Fischer, A., Fujita, K., Gadek, B., Ghazanfar, A., Hagen, J. O., Holmlund, P., Karimi, N., Li, Z., Pelto, M., Pitte, P., Popovnin, V. V., Portocarrero, C. A., Prinz, R., Sangewar, C. V., Sever- 
skiy, I., Sigurðsson, O., Soruco, A., Usubaliev, R., and Vincent, C.: Historically unprecedented global glacier decline in the early 21st century, J. Glaciol., 61, 745-762, https://doi.org/10.3189/2015JoG15J017, 2015.

Zhou, X., Buchli, T., Kinzelbach, W., Stauffer, F., and Springman, S. M.: Analysis of thermal behaviour in the active layer of degrading mountain permafrost, Permafrost Periglac., 26, 39-56 https://doi.org/10.1002/ppp.1827, 2015.
Zumbühl, H. J., Steiner, D., and Nussbaumer, S. U.: 19th century glacier representations and fluctuations in the central and western European Alps: an interdisciplinary approach, Global Planet. Change, 60, 42-57, 2008. 